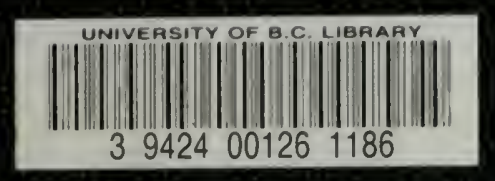

\author{
FOREST RESOURCES \\ OB \\ WESTERN AUSTRALIA \\ MUELLER
}




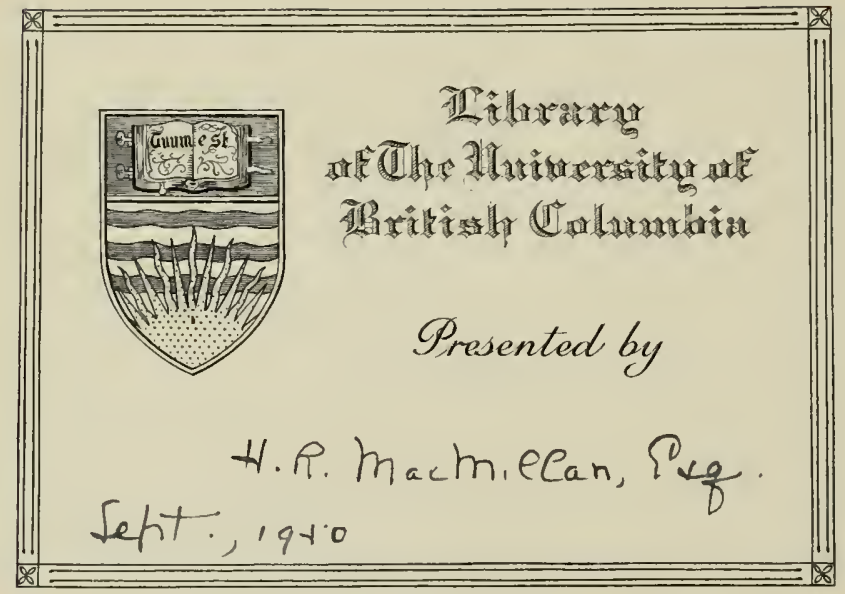

The HP. M. Nlace Vlillem

Gollection in Forestry

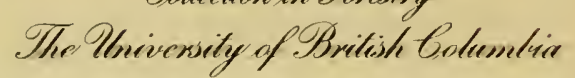


, 

The Percrest of N (Daltine With Yrespecture Comptement:

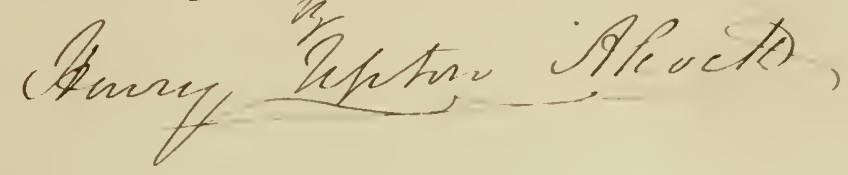

hellneme Guly 6th $1881 \mathrm{c}$ 152 Giscee frut?

\section{THE FOREST RESOURCES} OF

WESTERN AUSTRALIA 

R E P O R T

ON THE

\title{
FOREST RESOURCES
}

$\mathrm{OF}$

\section{WESTERN AUSTRALIA}

BY

\author{
BARON FERD. VON MUELLER \\ C.M.G., M.D., PH.D., F.R.S. \\ GOVERNMENT BOTANIST OF THE COLONY VICTORIA
}

\section{LONDON}

L. REEVE \& CO., 5, HENRIETTA STREET, COVENT GARDEN 



\section{CONTENTS.}

INTRODUCTORY REMARKS

I. Spontaneous Forest Resources of West Australia . . . . . . . 2

A. Eucalyptus timber . . . . . . . . . . . . . 2

1. Eucalyptus marginata . . . . . . . . . . . . 3

2. Eucalyptus calophylla . . . . . . . . . . . 4

3. Eucalyptus ficifolia . . . . . . . . . . . 5

4. Eucalyptus diversicolor . . . . . . . . . . . . . . . 6

5. Eucalyptus loxophleba . . . . . . . . . . . . 7

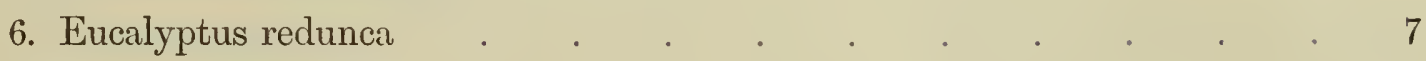

7. Eucalyptus cornuta . . . . . . . . . . . . 8

8. Eucalyptus gomphocephala

9. Eucalyptus rostrata . . . . . . . . . . . . . . 9

10. Eucalyptus rudis . . . . . . . . . . . . 10

11. Eucalyptus decipiens . . . . . . . . . . . 11

12. Eucalyptus microtheca . . . . . . . . . . . 11

13. Eucalyytus oleosa . . . . . . . . . . . . . . . 11

14. Eucalyptus longicornis . . . . . . . . . . . . 12

15. Eucalyptus salmonophloia . . . . . . . . . . 13

16. Eucalyptus salubris . . . . . . . . . . 13

17. Eucalyptus angustissima . . . . . . . . . . 14

18. Eucalyptus megacarpa . . . . . . . . . . . 14

19. Eucalyptus pyriformis . . . . . . . . . . 15

B. Timber-trees not Eucalypts-Casuarina, Agonis, Melaleuca, Frenela, Banksia,

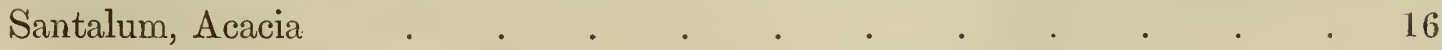

II. Chemical and Microscopical Examination of Eucalyptus Wood . . 17

III. Cultural Measures to enrich the West Australian Forests _ . • . 19

IV. Initiatory Measures suggested for establishing Forest Administration in West Australia . . . . . . . . . . . . . . . 26

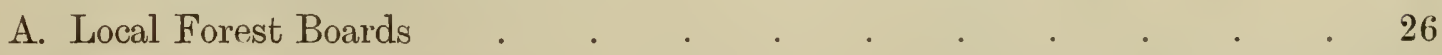

B. Revenue from Forest Areas . . . . . . . . . . . 27

C. Survey and Reservation of Forest Areas . . . . . . . . 27

D. Disposal of Timber, Fuel and other Forest Products _ . . . . . 27

E. Importation of Seeds and Plants . . . . . . . . . 28

F. Establishment of Local Nurseries . . . . . . . . 28

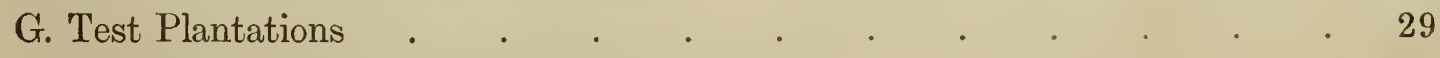

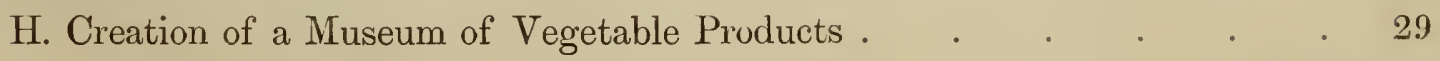


Digitized by the Internet Archive in 2010 with funding from University of British Columbia Library 


\section{ILL USTRATIONS.}

Plate I. Eucalyptus marginata.

II. Eucalyptus calophylla.

III. Eucalyptus ficifolia.

IV. Eucalyptus diversicolor:

V. Eucalyptus loxophleba.

VI. Eucalyptus redunca.

VII. Encalyptus cornuta.

VIII. Eucalyptus gomphocephala.

IX. Eucalyptus rudis.

X. Eucalyptus decipiens.

XI. Eucalyptus microtheca.

XII. Eucalyptus oleosa.

XIII. Eucalyptus longicornis.

XIV. Eucalyptus salmonophloia.

XV. Eucalyptus salubris.

XVI. Eucalyptus angustissima.

XVII. Eucalyptus pyriformis.

"XVIII. Fig. 1.-Transverse section of wood of Eucalyptus marginata; a. vascular tubes, b. parenchymatous cells, $c$. medullary rays, $d$. ligneous fibre. $\frac{250}{1}$.

Fig 2.-Tangential section of the wood of Eucalyptus marginata. $\frac{250}{1}$.

Fig. 3.-Radial section of the same. $2 \frac{50}{1}$.

Fig: 4. - Stomata of leaf of Eucalyptus salubris. Both surfaces alike. $\quad 130,000$ stomata to a square inch.
Plate XIX. Fig. 1.-Isolated organs of wood of Eucalyptus marginata, $\frac{250}{2} \cdot a$.Vascular tube, larger dots communicating with medullary cells. l). Prosenchyma. c. Parenchyma. d. Medullary cells. e. Transverse section of medullary cells.

Fig. 2.-Stomata (hypogenous only) of under-side of leaf of Eucalyptus marginata, 500,000 on a square inch.

Fig. 3a.-Stomata of under-side (hypogenous) of leaf of Eucalyptus calophylla. About 500,000 to a square inch. Size of stomata 0.015 to $0.025 \mathrm{~mm}$. lo. Pollen. $\frac{250}{1}$.

Fig. 4a.-Stomata (amphigenous) of leaf of Eucalyptus cornuta. About 120,000 to a square inch. Size of stomata 0.035 to $0.045 \mathrm{~mm}$. $b$. Pollen. $\frac{250}{1}$.

Fig. 5.-Isolated cellular and vascular constituents of the wood of Eucalyptus loxophleba treated with concentrated nitric acid and chromate of potash. a. Parenchyma. b. Medullary cells. c. Vascular cell (tube). d. Prosenchyma. $\frac{250}{1}$.

XX. Fig. 1.-Lower cuticle of leaf of Eucalyptus ficifolia, one areole. About 170,000 stomata to a square inch. $\frac{256}{1}$.

Fig. 2.-Tangential section of wood of Eucalyptus loxophleba. $\frac{250}{1}$.

Fig. 3.-Horizontal section of the same. $\frac{250}{1}$.

Fig. 4.---Radial section of the same. $\frac{250}{1}$. 



\section{R E P O R T}

ON THE

\section{FOREST RESOURCES OF WESTERN AUSTRALIA.}

\section{INTRODUC'TORY REMARKS.}

THe forest-regions of extra-tropic West Australia occupy an area equal to the whole territory of Great Britain; and it is singularly fortunate for the colony, that over this vast extent of wooded country a species of Eucalyptus (the Yarrah) prevails which for the durability of its timber is unsurpassed by any kind of tree in any portion of the globe. Under such circumstances the timber resources must be regarded as among the foremost in importance throughout the wide tracts of West Australia, even if the many other kinds of utilitarian trees, occurring in the more southern portion of that colonial territory, and the still more varied sorts of timber-trees, to be found within the intra-tropic regions of West Australia, were left out of consideration.

It is furthermore of particular advantage to the colony that its highly valuable Yarrah-timber is obtainable through at least five degrees of geographic latitude, and this within so short or moderate a distance of shipping places as to render it easily accessible to foreign traffic.

But as nowhere, not even in the most extensive woodlands, can the supply of timber from natural forests be considered inexhaustible, a rational far-seeing provision for the maintenance (if not for the enrichment) of its forest-treasures is needfiul for West Australia, however indiminishable these may appear to be at present.

In all densely-populated countries the consumption of timber is out of all proportion to the natural upgrowth or even cultural renewal of indigenous forests; and this disproportion of want to local supply will become greater and greater in the course of time, when denser settlements will be formed in those countries, from whence now subsidiary or main timber supplies are obtained. Hence also the celebrated Yarrah-timber will become still more highly appreciated by subsequent generations ; and as its replacement in cleared forests cannot be effected with the same celerity as that of sereral other less valuable timber producing Eucalypts, we may assume that any Yarrah-forest, if allowed to go to destruction, would probably not be replaced more quickly than those of many European or NorthAmerican trees, still largely (but not likely for ever) yielding timber for export, even if agricultural and pastoral pursuits, with their ever-increasing demands for ground, would not likewise diminish the natural areas of the Yarrah-Eucalypt in West Australia. Moreover, the forest questions have their particularly important bearings, inasmuch as the West Australian territory, stretching through such wide geographic parallels, can rear in reality any kinds of timber of the globe by cultural processes, the trees of colder countries being adapted to the cool and humid climate of the most south-western portion, whereas trees of the tropic zone would prosper along the north-west coast. This is not without significance, when we reflect, that neither the North-American, nor the Baltic, nor any other northern countries will continue to furnish the indispensable deal for indefinite periods to other parts of the globe, where pine-woods do not exist either naturally or copiously; in the same manner, 
every tropical country (and this applies also largely to West Australia) should strive to transfer the leading timber-trees of the hot zone to its own shores for independent supplies, more especially as tropical species, unlike many from the colder zones, are seldom gregarious anywhere. Considerations of forest-resources are therefore of particularly weighty meaning to West Australia under manifold aspects.

For clearness' sake it is deemed desirable to treat in this succinct report the forest question of West Australia in four divisions :-

1. To elucidate phytographically the various native timber-trees, hitherto leadingly there in use, by descriptive notes and lithographic illustrations for easy and accurate specific recognition, and to add some brief data on their respective utilitarian importance.

2. To explain the chemic and microscopic characteristics, indicative of various qualities of Eucalyptus-wood.

3. To show by what cultural and industrial measures the yields and riches of the West Australian forests could be largely enhanced.

4. To express my views, how in a young colony with a very sparse population, an inexpensive forest administration could be effectually initiated.

A brief document, like the one intended for this occasion, cannot be expected to treat exhaustively the forest-interests of a country as large as European Rlissia, and with a clime far more genial, more particularly as the writer had only on three occasions the opportunity of traversing portions of the vast extent of West Australia, and then only for a few weeks each time-in i856 (as naturalist of the expedition sent out by the Duke of Newcastle, under Aug. Gregory), some of the northeastern regions along Sturt's river from latitude $18^{\circ}$ to $22^{\circ} 20^{\prime}$ south; in 1867, the Stirling range and surrounding country, and the vicinity of King George's Sound; and in 1877, the country from Champion Bay to Shark Bay, and also from Swan River to Geograph Bay, and thence to the Shannon and Gordon rivers-these last-mentioned journeys being carried out under special facilities, liberally afforded by the West Australian Government.

\section{I.-SPONTANEOUS FOREST RESOURCES OF WEST AUSTRALIA.}

\section{A.-Eucalyptus Timber.}

From the extra-tropic territory of West Australia, as far as phytographically explored, about half a hundred species of Eucalypts have hitherto been made known; while we are acquainted with about thirty tropical species, which extend into the West Australian territory. A portion, however, of these eighty Eucalypts form only small trees, or are of shrubby growth. The technic value of many even of the arboreous species, particularly those of inland districts, and those of the intra-tropic latitudes, have been up to this time almost completely unascertained for the purposes of artisans. In the following pages, therefore, only those kinds are alluded to of which the timber has come into general use, and has been tested by lengthened experience; but it may be assumed that many of the other. Eucalypts of the West Australian dominions can be brought advantageously into industrial use ; and inasmuch as the north-west coast possesses several excellent harbours, the shipment of many new kinds of serviceable Eucalyptus-timber for export is likely to take place in years to come, when also that ample territory will become more densely settled by colcnists. It may here be observed that, fas ar as known, Eucalypts form also in the intra-tropic portions of West Australia the prevailing timber, although they are in many places largely interspersed there with trees of Indian types.

It must be patent to every contemplating mind that a most accurate knowledge of the characteristics of each species of tree is imperatively necessary to discriminate between allied kinds, the 
timber of which, notwithstanding close specitic affinity of the trees themselves, is often found to be widely different in its adaptability to particular work, or in its resistance to the ravages of insects or other destructive creatures, whether of animal or (as fungi) vegetable growth. Besides, an intimate knowledge of each particular species will also render any culture of them easier, in choosing for each the clime and soil respectively best adapted for them. Hence descriptive details and lithographic illustrations are now offered, to render the recognition of at least the leading SouthWest Australian species safe and altogether free from difficulty.

1. Eucalyptus marginata. Smith, in the Transactions of the Linnean Society of London, vi. 302 (1802). Bentham's Flora Australiensis, iii. 209. The Yarrah-tree, or West Australian. Mahogany-Eucalypt.

Leaves scattered, on moderately long stalks, from oval to narrow-lanceolar, somewhat curved, acuminate, paler and not shining underneath, with numerous very spreading veins, the intramarginal vein at some slight distance from the edge; flower-stalks almost all axillary, with three to twelve flowers, slender and usually compressed; the stalklets (of each individual flower) longer than the tube of the calyx; lid from semi-elliptical to narrow conical, about twice as long as the tube; stamens all perfect, flexuose, but not bent back before expansion; anthers heart- or kidneyshaped, opening by longitudinal slits ; fruit ovate-globular, truncute, the margin of the summit flat; valves three, enclosed or but slightly exserted; seeds without membranous appendage.

The Yarrah-tree extends over the greater portion of the country from the Moore river to King George's Sound, advancing also to Cape Leeuwin, forming mainly the forests of these tracts. Isolated patches of straggling trees occur in some places beyond the main rrea here indicated. It does not enter to any extent the forests of Karri and York Gum-trees. The tree exceeds occasionally 100 feet, but rarely 150 feet in height. On account of its persistent and somewhat fibrous bark, it would be classed with the "stringy bark trees" of the eastern colonies, had it been an inmate of the forests there. Hence in the cortical system it must be inserted among the Pachyphloiae. The wood has attained a world-wide celebrity; when especially selected from hilly localities, cut while the sap is least active, and subsequently carefully dried, it proves impervious to the borings of the Chelura, Teredo, and Termites ; it is therefore in extensive demand for jetties, piles, railway-sleepers, fence-posts, and all kinds of underground structures, and it is equally important as one of the most durable for the planking and frames of ships. It is also much used locally for flooring, rafters, spars, and furniture; though hard (particularly that of the ironstone ranges) it is easier worked than wood of E. loxophleba, and E. redunca. The timber from hills is darker, tougher, and heavier than that from plains. The weight of well-seasoned wood is, at an average, about sixty-four pounds for the cubic foot. It is one of the least inflammable for building structures, and one of the very best in West Australia for charcoal, not burning so readily into ashes as most kinds of Eucalyptus-wood. Stems have been measured eighty feet to the first branch, with a circumference of thirty-two feet at five feet from the ground. For shingles the wood is doubly as durable as even that of Casuarina Fraseriana, though it is more apt somewhat to warp, if not well selected.

In explaining in this and all other cases the uses of any particular Eucalypt, it must be understood that it is not attempted in these pages to sum up all the purposes for which any particular species of timber can be employed. This cannot fully and satisfactorily be done from such inquiries as, amidst multifarious engagements and observations, the writer could carry out during the short periods of his travels in West Australia, but must be left to the circumspectness of local artisans, whose accumulated experiences during the fifty years' existence of the colony must have become both extensive and reliable. This much, however, can be foreseen, that $\mathrm{E}$. marginata is destined to supply one of the most lasting of hardwood timbers for a long time to come, at the least costly rate, to very many parts of the globe.

The specific name adopted by Sir James Smith for Eucalyptus marginata is not very expressive, 
as it relates merely to the somewhat thickened margin of the leaves, which indeed is not more evident than in most Eucalypts. The founder of the Linnean Society received his specimens from Archibald Menzies, naturalist to the expedition of Captain Vancouver, who in 1791 discovered and named King George's Sound, and who was thus also instrumental in rendering known first of all many South-West Australian plants.

\section{Explanation of Lithogram. Plate I.}

The main Lithogram (Plate I.) exhibits in this, and all subsequent Plates, the natural size of the foliage, flowers, and fruits.

1. Longitudinal section of unexpanded flower; 2. Front view of anther (with portion of the filament); 3. Back view of the same ; 4. Style, with its minute stigma ; 5. Longitudinal section of fruit; 6. Transverse section of fruit; 7. Sterile seeds ; 8. Fertile seeds ; 9. Embryo.-1 to 4 and 9 , magnified; 5 to 8 , natural size.

2. Eucalyptus calophylla. R. Brown, in the Journal of the Royal Geographical Society, 1831, 20. Bentham's Flora Australiensis, iii. 255. 'The Red Gum-tree of South-West Australia (but not of the interior or the eastern colonies).

Leaves scattered, on long stalks, broad-or lanceolar-ovate, acute, of rather thick consistence, much paler and not shining underneath, with numerous very spreading subtile closely-parallel veins, the peripheric vein contiguous with the margin; umbels four- to six-flowered, interminal panicles, or some few axillary and solitary; stalklets quadrangular, generally about as long as the stalks and as the pear-shaped calyx; lid depressed-hemispheric, very short, only about half as broad as the tube of the calyx; stamens all perfect; filaments inflexed before expansion; anthers cuneate- or ovaloblong, with parallel cells opening lengthwise ; fruits large, urceolar-ovate, three- to four-celled, not angular; valves short, deeply enclosed; fertile seeds very large, brown-black, at the edge acute, but not produced into a membranous appendage.

Interspersed with the Yarrah-Eucalypt throughout nearly the whole area of that species, but less gregarious, though next to it the most frequent of South-West Australian trees, seemingly reaching its northern boundary on the Hill river and its southern at King George's Sound, mixed also into the forests of $\mathrm{E}$. loxophleba, but not into those of $\mathrm{E}$. diversicolor.

The most umbrageous among tall Eucalypts of the colony, on account of its leaves turning the surface more than the edge to the zenith, a characteristic which it shares with but few Eucalypts although with most other trees of the globe. The bark is persistent, rough, furrowed, and pervaded with Kino, for which reason this species would be ranked with the Ironbark-trees of Eastern Australia, if indigenous there. Its place in the cortical system is among the Schizophloiae. The foliage of younger seedlings is remarkable, their stems, leaf-stalks, and leaves being beset with bristly hairs, while the leaves are affixed, not like leaves of the more aged tree to their stalks at the base, but are inserted at a considerable distance above the base, as shown in the background of the lithographic iilustration.

The growth of $\mathrm{E}$. calophyila is far more rapid than that of E. marginata. The tree yields locally much timber for naves, harrows, ploughs, shafts, spokes, rafters, handles, frames, rails, and various building operations; but the wood cannot be utilised for underground work, being subject to decay when so placed. It is generally more free of Kino-substance when grown on alluvial soil, and is tougher than that of E. marginata, but not so strong as that of E. loxophleba; this is the only tree in West Australia producing Kino copiously, this tanning substance being drawn into use not only locilly as an admixture to the bark of Acacia saligna, but exported also both in a liquid and a dry state. In height E. calophylla is not inferior to E. marginata, and stems have exceptionally been observed with a diameter of ten feet.

Robert Brown, when as companion of Captain Flinders in 1802 he visited the south coast of 
West Australia, bestowed the specific name on this tree seemingly for a double reason, because the foliage is far more beautiful than that of most Eucalypts, and also because the venation of the leaves reminds of that of the tropicai genus Calophyllum of Linné.

\section{Explanation of Lithogram. Plate II.}

1. Longitudinal section of unexpanded flower; 2. Front view of a stamen; 3. Back view of a stamen; 4. Style with stigma; 5. Transverse section of fruit; 6. Longitudinal section of fruit; 7. Sterile seeds ; 8. Fertile seeds; 9 . Embryo. -1 to 4, magnified; 5 to 9, natural size.

3. Eucalyptus ficifolia. F. v. Mueller, Fragmenta Phytographiae Australiae, ii. 85 (1860.) Bentham's Flora Australiensis, iii. 256. The crimson-flowered Eucalypt.

The characteristics of this species are so similar to those of E. calophylla, that it is deemed unnecessary to offer a diagnosis. The diversity of $\mathrm{E}$. ficifolia rests on the following points:-The tree is of smaller stature, the greatest height not exceeding fifty feet; the bark is generally still more deeply furrowed; the leaves are usually longer, more acuminate and less dotted; the calyces are on the whole rather larger, somewhat tinged with red, longer in proportion to their width; the filaments are of a magnificent crimson; the seeds are of a pale colour and provided with a membranous appendage. To this may be added, that the seedling at no time of its growth is conspicuously rough from bristlets, nor do the leaves even in the earliest period of the plant show the insertion to be supra-basal to the stalk.

The geographic distribution of this species is very limited; it extends, according to Messr's. Muir and Maxwell, from the western side of Irwin's Inlet to the mouth of the Shannon, the forests of this tree forming a belt not quite near to the coast nor very remote from it, the furthest distance inland being about eight miles. Hardly anything more gorgeous can be imagined than the forest of E. ficifolia about the month of February, when the brilliant trusses of flowers diffuse a rich red over the dark-green foliage of the whole landscape.

Although of the value of the timber nothing as yet is known, this species could not be passed in this report, it being even almost unknown to West Australian colonists, though its floral magnificence was demonstrated already in 1867 from trees reared by the writer in the Botanic Garden of Melbourne. More recently it has been introduced into the countries around the Mediterranean Sea, and into several other parts of the globe free of frost. A lucrative trade in seeds of E. ficifolia is sure to arise, as through my exertions this species, like many other West Australian plants, has now become widely appreciated.

The tree ought also in West Australia to be reared as an umbrageous, highly ornamental avenue-tree.

The species was first described from a mere fruiting branchlet, and received its name from the resemblance of its foliage to the leaves of several species of Ficus, of the series to which the Indiarubber Fig-tree belongs.

Only two other tall Eucalyptus-trees can perhaps be compared in floral splendour to the present species-namely, E. miniata (A. Cunningham, in A. Walpers's Repertorium, ii. 925, anno 1843), and E. phoenicea (F. v. M., in the Journal of the Linnean Society, iii. 91, anno 1859), both extending from Carpentaria into the most northern regions of the West Australian territory, the colour of their flowers being a fiery orange.

\section{Explanation of Lithogran. Plate III.}

1. Longitudinal section of unexpanded flower; 2. Front view of a stamen; 3 . Back view of a stamen; 4. Pollen grains; 5. Style; 6. Longitudinal section of fruit; 7. Transverse section of fruit ; 8. Sterile seeds ; 9. Fertile seeds ; 10. Embryo in situ; 11. Embryo unfolded.-All magnified. At the upper right-hand corner of the lithogram is shown the branch and leaves of a seedling plant. 
4. Eucalyptus diversicolor. F. v. Mueller, Fragmenta Phytographiae Australiae, iii. 131 (1863). Bentham's Flora Australiensis, iii. 251. The Karri-tree.

Leaves scattered, oval-lanceolate, somewhat sickle-shaped, paler beneath, traversed by numerous very spreading and subtile veins, the intra-marginal vein somewhat distant from the edge ; umbels axillary, solitary, three- to six-flowered, on almost cylindric stalks ; calyces ellipsoid, with attenuated base on stalklets hardly as long; tube not angular, nearly twice as long as the lid ; stamens inflexed before expansion; anthers almost heart-shaped, opening with longitudinal slits ; fruit truncate-ovate, three-celled; valves enclosed; seeds small, without any membranous appendage.

In the humid country at and near the Warren, Shannon, Donelly, Walpole, and Gardner rivers, towards the coast constituting forests, occurring also as far east as Mount Manypeak and the Porongerup, and westward fully to Cape Leeuwin. This gigantic tree has only one single rival on our island-continent, the Eucalyptus amygdalina (var. regnans) of South-East Australia, the grand features of which it completely repeats. Startling accounts of monster specimen trees are on record, and its maximum height is certainly not over-estimated at 400 feet. Messrs. Muir measured stems 300 feet long up to the first limb. When closely growing the young trees have a very slender stem, so much so, that a tree 180 feet high, and with comparatively but little foliage, may have a stem not over one foot in diameter. Captain Pemberton Walcott found the circumference of one particularly gigantic tree to be 60 feet around the base.

Although we do not know what giants the forests of Central Africa, many unexplored parts of continental and insular India, New Guinea, and also perhaps South America may still present, yet so far as known to West Australia and Victoria must at present be awarded the palm for the tallest trees in the world, the only ones which so far can be brought into comparison with them being the Wellingtonia-pine and Sequoia-pine of western North America, unless perhaps Pinus grandis, Pinus Menziesii, Pinus Lambertiana, and Pinus Douglasii, also enter into competition as regards enormous height.

Widths of timber of as much as twelve feet can be obtained. The whitish smooth bark of the huge stems of mast-like straightness impresses a peculiar feature on the Karri-forests, and places this species into the Leiophloiae of the cortical system. These particular woodlands not being very accessible our experience of the value of the timber is still imperfect, but the Karri-timber will become doubtless important for the lumber trade, whenever the harbours between King George's Sound and Cape Leeuwin shall have been fully opened up for commerce and settlement. The wood is regarded as elastic and durable, but it is not so easily wrought as that of E. marginata; it has proved valuable for shafts, spokes, felloes, and rails, and is particularly sought for large planks. The writer has introduced the tree into Victoria, also into South Europe and North Africa, and to some extent elsewhere, it being easily manageable in culture and of comparatively quick growth. Abroad this species, on account of its huge dimensions, passes very often as Encalyptus colossea; but the name here adopted according to the laws of priority cannot be changed now; it arose at a time when the colossal height of $\mathrm{E}$. diversicolor was quite unknown. The specific name was derived from the paleness of the leaves on the lower side, unusual among allied species.

\section{Explanation of Iithogram. Plate IV.}

1. Two forms of the unexpanded calyx; 2. Longitudinal section of unexpanded flower; 3. Front view of stamen; 4. Back view of stamen; 5. Pollen grains magnified 300 times diametrically; 6. Pistil ; 7. Fruit seen from above; 8. Abnormal form of fruit; 9. Longitudinal section of fruit; 10. Transverse section of fruit; 11. Sterile seeds; 12. Fertile seeds; 13. Embryo; 14. The same expanded.-The comparison with the principal drawing, which is of natural size, will indicate the degree of enlargement of the analytic figures. 


\section{Eucalyptus loxophleba. Bentham, Flora Australiensis, iii. 252 (1866). The York} Gum-tree.

Leaves scattered, curved-lanceolar, acuminate, equally green on both sides, their veins somewhat distant and prominent, the peripheric vein distinctly removed from the margin; umbels axillary, solitary, six- to twelve-flowered, on cylindric or faintly compressed stalks; tube of the calyx obconic, not angular, attenuated into a short stalklet; lid hemispheric or pyramidal-conical, shorter than the tube of the calyx; stamens short, inflexed before expansion; anthers minute, opening with longitudinal slits; fruit truncate-ovate, three to four-cellea, its rim narrow ; the valves deeply enclosed ; seeds small, without any appendage.

On the eastern tracts of the Darling ranges a main constituent of the forests, extending only through a narrow strip of country eastward beyond them, spreading northward in a variety called by the natives Yandee, to the Murchison river, and, according to Mr. J. Forrest, eastward as far as Kojenup, and thence southward to near King George's Sound.

This tree occupies more particularly the eastern slopes of the Darling range, not entering the western tracts where the Yarrah-Eucalyptus forms the main forest. It is content with poor soil. Its abundance near the town of York suggested the English name.

Never a very high tree, seldom exceeding eighty feet, not rarely of crooked growth ; stem rarely above four feet in diameter. The bark is persistent and rough, and draws this species into the Rhytiphloiae; inside it is red like that of the Morrel-Eucalypt. The wood is regarded as the very best in West Australia for naves and felloes, on account of its toughness; though not sufficiently fissile to be split into rails, it is for this very reason preferentially sought for many superior purposes by artisans.

Mr. Bentham derived the name of this species from the direction of the veins of the leaves.

\section{Explanation of Lithogram. Plate V.}

1. Longitudinal section of unexpanded flower; 2. Front view of a stamen; 3. Back view of a stamen ; 4. Style and stigma; 5. Longitudinal section of fruit; 6. Transverse section of fruit; 7. Sterile seeds; 8. Fertile seeds ; 9. Embryo; 10. Cotyledons stretched out to exhibit their form and that of the radicle.-All magnified.

6. Eucalyptus redunca. Schauer, in Lehmann's Plantae Pressianae, i. 127 (1844). Bentham's Flora Australiensis, iii. 253. The Wandoo-tree.

Leaves scattered, ovate- or falcate-lanceolar, acuminate, their veins subtile and rather remote, the peripheric vein distant from the margin; umbels six-to twelve-flowered, on an usually compressed stalk; tube of the calyx narrow, attenuated into a short stalklet, twice or thrice shorter than the conical-pointed lid; stamens before expansion inflexed; anthers oblong, opening by longitudinal slits; fruit three- to four-celled, ovate or more oblong, truncate, but usually contracted at the summit; the rim narrow; valves enclosed or only their apex exserted; fertile seeds small without appendage.

Prevailing as a forest-tree on the eastern slopes of the Darling ranges, extending more sparingly northward to the Murchison river, and south-eastward to Cape Riche, as far as hitlerto recorded.

It is a smooth-barked tree and the principal White Gum-tree of West Australia, so called on account of the hue of its bark, which on friction imparts a white colour, and is not shining.

The height of the tree only exceptionally exceeds 120 feet, and like several other Eucalyptus-trees it flowers often already in a shrubby state, when only"a few feet high. The stem is known to have attained occasionally a diameter of seventeen feet.

In the cortical system it belongs to the Leiophloiae.

The wood is very pale, hard, and durable; it is much used for cart-shafts, spokes, cogs, rollers, naves, and felloes; indeed, for these purposes it is on the whole regarded as the best in West 
Australia, although on account of its toughness it is difficult to work. The seasoned wood is so heavy as to attain a weight of seventy pounds to the cubic foot.

The tree is so indifferent in regard to soil as to prosper even on cold clayey or poor gravelly flats, where humidity stagnates in the wet season.

Dr. Schaner, of Bresiau, who obtained specimens from Preiss's collection, chose the name of the species (not very aptly) from the curvature of the lid.

\section{Explanation of Lithogram. Plate VI.}

1. Calyces of two varieties, natural size; 2. Longitudinal section of bud; 3 . Front view of a stamen; 4. Back view of a stamen; 5. Style with stigma; 6. Longitudinal section of fruit; 7. Transverse section of fruit; 8. Sterile seeds; 9. Fertile seeds; 10. Embryo; 11. Cotyledons moved from the radicle. -2 to 11 , magnified.

7. Eucalyptus cornuta. Labillardière, Relation du Voyage à la Recherche de La Pérouse, i. 403, t. 20 (1799). Bentham's Flora Australiensis, iii. 234. The Yate-tree.

Leaves scattered, oblong-ovate or falcate-lanceolar, equally green on both sides; their veins thin, spreading, the peripheric vein somewhat remote from the margin ; flowers from three to twenty-one, crowded on long solitary axillary cylindric or somewhat compressed stalks; lid hoin-like, several times longer than the obconic bell-shaped tube of the calyx ; stamens straight before expansion ; filaments as well as the style yellow, very long; anthers comparatively long, narrow-ellipsoid, opening with longitudinal slits; fruit three- to four-celled; valves elongated, exserted, pyramidally connivent, cohering far up and passing into the style; fertile as well as sterile seeds without any appendage.

From the vicinity of Geograph Bay, at least as far as Cape Riche, the "Yate" is of rapid growth. In Lucknow, according to Dr. Bonavia (to whom I supplied the seeds), it attained in the first year eight to ten feet, and the young plants did not suffer there from the tropical rains, as is the case with so many other Eucalypts. I witnessed the quickness of its growth also at Melbourne, on even poor ground. The tree advances in age to a very considerable height. The bark of at least part of the stem is smooth and pale, hence the Yate must be placed among the Lerophloiae, unless it is preferred to arrange it with the Hemiphloiae. Its elastic and very hard wood is splendid for agricultural implements, boat-ribs, and is for wheelwrights' work as good as that of Eucalyptus loxophleba, while for cart-shafts it is regarded as equal to the best English ash-wood.

Mr. Muir noted a variety of Yate, which has the mass of its foliage flat-topped; besides this there is another variety, considered by some as a distinct species, the Eucalyptus Lehmanni (Preiss in Lehmann's Plantae Preissianae, i. 127), which mainly differs in having the calyces of the flower's and fruits connate into one mass.

Monsieur Labillardière discovered Eucalyptus cornuta in 1792 at Cape Leeuwin, when naturalist of the expedition sent out under the command of Admiral D'Entrecasteaux, in search of the missing ships of the unfortunate Count La Pérouse. The specific name was aptly given in allusion to the lorn-like lid of the flowers.

\section{Explanation of Lithogram. Plate VII.}

1. Longitudinal section of unexpanded flower; 2. Summit of longitudinal section of unexpanded flower of a larger variety; 3. Front view of the upper part of a stamen; 4 . Back view of the same; 5. Pistil ; 6. Longitudinal section of fruit; 7. Transverse section of fruit; 8 . Sterile seeds; 9. Fertile seeds; 10. Embryo.-1, 6, and 7, natural size; 2 to 5 and 8 to 10 , magnified. 
8. Eucalyptus gomphocephala. De Candolle, Prodromus Systematis Naturalis Regni Vegetabilis, iii. 220 (1828). Bentham's Flora Australiensis, iii. 231. The Tuart-tree.

Leaves scattered, on rather long stalks, sickleshaped-lanceolar, equally green on both sides, traversed by very fine and spreading veins, the longitudinal vein on each side very close to the margin; umbels axillary, solitary ; three- to six-flowered; stalks broad, much compressed; stalklets none or extremely short; lid hemispheric or semiovate, hard, very considerably broader than the width of the obconic or somewhat urceolar tube of the calyx; stamens inflexed before expansion ; anthers oblong-oval, bursting by longitudinal slits; style very short; fruit almost bell-shaped, rather large, somewhat angular, four-celled, their rims convex and broad; valves exserted; seeds without appendage.

In the calcareous coast-tracts at intervals from the vicinity of Swan River to near Cape Leeuwin. Never a tall tree, rarely attaining a height of over 100 feet, but the stem often of considerable diameter. Bark persistent, wrinkled, which thus designates this species as belonging to the Rhytiphloiae. Wood in use for shafts, naves, felloes, and various implements; it is solid, hard, and does not rend; it has come into use for shipbuilders' purposes and various artisans' work.

The specific name arose from the extreme turgidity of the lid, as compared to the width of the tube of the calyx. This characteristic renders this species one of the most easy for recognition.

\section{Explanation of Lithogram. Plate VIII.}

1. Longitudinal section of unexpanded flower; 2. Front view of anther; 3. Back view of anther ; 4. Pistil ; 5. Longitudinal section of fruit; 6 . Transverse section of fruit; 7. Sterile seeds; 8. Fertile seeds; 9. Embryo ; 1.0. The same unfolded to show the radicle fully.-All enlarged.

9. Eucalyptus rostrata. Schlechtendal, Linnaea xx. 655 (1S47). Bentham's Flora Australiensis, iii. 240. The Flooded Gum-tree of the interior.

Leaves scattered, sickleshaped-lanceolar, of rather thin consistence, equally green on both sides; the veins fine, numerous, and pinnately spreading, the peripheric vein distinctly removed from the margin; umbels with from five to nine flowers, on a slender stalk; tube of the calyx semiglobular, much shorter than its thin stalklet; lid hemispheric towards the base, long, acutely and rather suddenly attenuated to its summit, or seldom gradually narrowed into a blunt apex; stamens inflexed before expansion; anthers roundish-ovate, opening with longitudinal slits; fruit small, towards the base almost semiglobular, its vertex protruding with the broad ascending margin; valves emersed, short; seeds without any appendage.

Generally lining the watercourses of the far interior, observed by me in the littoral portion of West Australia, southward only to the Murchison river, but occurring also in the oases, where humidity lodges, towards Shark Bay, thence often along the streams of also the tropical portion of West Australia.

This highly important tree indicates to explorers the lines of creeks, and to pastoral settlers, chiefly in the more central regions of Australia, the watering-places for their flocks. It is the famous "Red Gum-tree" of South Australia, Victoria, and the interior of New South Wales, but passes in Queensland as "Flooded Gum-tree." It is one of the few Eucalypts which stretch from the west-coast of the Australian continent to the east and north-east coasts, reaching also east of Great Bight the southern shores. This tree is seldom over 100 feet high; the bark is whitish, and remains smooth on account of the periodic secession of the outer layers, hence the species belongs to the Leiophloiae.

In the extraordinary endurance of its timber in underground structures, it has only one Australian rival-namely, the Yarrah-but surpasses that celebrated tree in ease and quickness of its growth. It can be reared even in often inundated places, which thus might be utilised for the 
production of one of the best timbers of the globe. It is also the leading species for forestculture in tropical lowlands. For piles, culverts, telegraph-posts, railway-sleepers, and fence-posts no better timber can be chosen anywhere. For shipbuilding it is also in manifold ways available, as it resists, when well selected, the attacks of the crustaceous Chelura and Limnoria, and of the Teredo-molluse, as well as of the Termites. The wood, moreover, is readily utilised for furniture and for endless building operations, much sought also for railway buffers, not to speak of minor artisans' works, for which it is eminently fitted.

The weight of a cubic foot of seasoned wood varies from fifty-three to fifty-eight pounds. The tree exudes also an excellent Kino for medicinal and tannic use.

Dr. von Schlechtendal, of Halle, gave the tree its specific name in allusion to the beak-like elongation of the lid of the calyx.

10. Eucalyptus rudis. Endlicher, in Baron von Huegel's Enumeratio Plantarum Novae Hollandiae Austro-Occidentalis, 49 (1837). Bentham's Flora Australiensis, iii. 244. One of the Flooded Gum-trees of the south-western coast-country.

Leaves scattered, from broad- to narrow-lanceolar, curved, copiously dotted with pellucid oil-glands, but not shining; the veins numerous, subtile, and very spreading; the peripheric veins somewhat distant from the margin ; umbels stalked, axillary, solitary, three- to eight-flowered ; calyces on conspicuous stalklets, the tube almost turbinate, nearly as long as or shorter than the semiovateconic lid; stamens inflexed before expansion; anthers obovate, with contracted base, opening with longitudinal parallel slits; style short, twisted; fruit turbinate-hemispheric, three- to five-celled, dilated around the margin, their rims narrow; valves exserted, short; seeds without appendage.

On river-banks from Swan River to Cape Leeuwin, and eastward at least as far as the Gardiner river.

This species has been described and illustrated on this occasion, not as an important timbertree-its wood serving seemingly for little else than fuel-but to demonstrate the uncertainty of vernacular names bestowed by colonists on Eucalypts in various parts of Australia. Thus we have not less than three distinct Flooded Gum-trees in Western Australia alone-viz., Eucalyptus rostrata, E. rudis, and E. decipiens. The last-mentioned species is described also by Dr. Endlicher, of Vienna, in the quoted work of the nobleman (and subsequent ambassador) who visited the country between Swan River and King George's Sound as long ago as 1833, and brought with him for scientific elucidation a host of West Australian plants, at a time when so little especially of the Swan River vegetation was known. Eucalyptus decipiens differs already from E. rostrata and E. rudis in having its flowers and fruits sessile on the general stalk, also in the form and debiscence of its anthers, which are globular and open rather by pores than by slits. Neither Eucalyptus rudis nor E. decipiens are very large trees; and both, on account of their persistent rough bark, belong to Rhytiphloiae, being thus signally different from the valuable Flooded Gum-tree of the interior. The writer is unacquainted with any technic value which the wood of $\mathrm{E}$. decipiens may possess; but $\mathrm{E}$. rudis deserves notice on this occasion, as being among the few West Australian species which would furnish lucrative material for the distillation of the antiseptic and also industrially so valuable Eucalyptus oil.

\section{Explanation of Lithogram. Plate IX.}

1. Longitudinal section of a flower bud;2. Front view of stamen; 3. Back view of stamen; 4. Pistil; 5. Longitudinal section of fruit; 6. Transverse section of fruit; 7. Sterile seeds; S. Fertile seeds; 9. Embryo; 10. Cotyledons moved asunder to show the radicle-All analytic details enlarged. The branchlet with broad leaves in the background represents, in this and all other Plates, the species in its youngest state. 
11. Eucalyptus decipiens. Endlicher, in Huegel's Enumeratio Plantarum Novae Hollandiae Austro-Occidentalis, 49 (1837). Bentham's Flora Australiensis, iii. 218. One of the Flooded Gum-trees of South-West Australia.

Leaves scattered, from ovate to lanceolar, acuminate, dull green on both pages; their subtile veins very divergent, the peripheric vein somewhat distant from the margin ; flowers axillary, from five to fifteen, crowded on a short staik without separate stalklets; tube of the calyx turbinate, as long as or shorter than the broad- or narrow-conical lid; stamens inflexed before expansion; anthers minute, spherical, opening rather with pores than slits; fruit small, its form fluctuating between turbinate and truncate-globular, the rim somewhat broad and flat; valves emersed; seeds without appendage.

From Swan River to Cape Riche, especially along watercourses or on river-flats, but occasionally also on limestone-hills.

For further observations, see preceding species. The geographic range of this, and indeed of most of the West Australian Eucalypts, is as yet not accurately ascertained.

\section{Explanation of Lithogram. Plate X.}

1. Operculum; 2. Stamens in bud, outer view; 3. Longitudinal section of flower bud; 4. Front view of stamen; 5. Back view of stamen; 6. Pistil ; 7. Longitudinal section of fruit; 8 . Transverse section of fruit; 9. Sterile seeds; 10. Fertile seeds; 11. Portion of a leaf.-All (but variously) magnified, but the main figure of natural size.

12. Eucalyptus microtheca. F: von Mueller, in the Proceedings of the Linnean Society, iii. 87 (1858). E. brachypoda, Turcz.; Bentham's Flora Australiensis, iii. 223.

Leaves scattered, on rather short stalks, narrow-lanceolar and somewhat sickle-curved, opaque on both sides, faintly veined, the intra-marginal vein almost contiguous to the edge ; umbels few-flowered, mostly in terminal panicles; calyx very small, its tube hemispheric, about as long as the almost conical lid; stamens very short, inflexed before expansion; anthers extremely minute, globular ; fruit very small, semiglobular or semiovate, three- to four-celled; valves somewhat exserted; seeds without appendage.

From the Murchison river scattered northward as far as Cambridge Gulf, also widely distributed through the vast interior of Australia, particularly along occasionally wet depressions, reaching to the Flinders and Darling rivers, and also nearly to the east-coast of Queensland.

Usually this tree is not very large, though of sufficient dimensions to yield timber, and it exceptionally attains 150 feet in height. It belongs to the Rhytiphloiae, or perhaps to Hemiphloiae, as the bark is only partially persistent on the branches. It is fond of swampy ground like Eucalyptus rostrata, with which it is associated in many places. The wood is lasting in and out of the ground, hence well adapted for waterworks, railway posts and sleepers, and a multitude of carpentry works; it is dark, hard, heavy, and elastic.

\section{Explanation of Lithogram. Plate XI.}

1. Longitudinal section of flower bud; 2. Front view of stamen; 3. Back view of stamen ; 4. Pistil; 5. Longitudinal section of fruit; 6 . Transverse section of fruit, 7 . Sterile seeds; 8. Fertile seeds.--All analytic figures enlarged.

13. Eucalyptus oleosa. F. von Mueller, in Nederlandisk Kruidkundig Archief, iv. 137 (1859). Bentham's Flora Australiensis, iii. 248.

Leaves scattered, narrow- or oblong-lanceolar, on rather short stalks, recurved-acuminate, shining, dotted with innumerable oil-glands, faintly veined, the peripheric vein slightly distant from the margin; umbels stalked, axillary, solitary, four-to eleven-flowered; tube of the calyx obconic or semiovate, usually on a very short stalklet, hardly angular, shorter than the mostly conical blunt or 
icute lid; stamens short, inflexed before expansion; anthers minute, ovate, with parallel distinct cells ; fruit small, truncate-ovate or almost truncate-globular, three- or four-celled; valves subulate, exserted; seeds without appendage.

In the interior extra-tropical desert-country, forming a portion of the so-called "Mallee-scrub," which extends over a vast portion of the deserts of Australia.

This species remains often in a bushy state only, but attains also the size of a small tree. The bark is mostly persistent on the trunk, but secedes from the branches; accordingly Eucalyptus oleosa belongs to the series of Hemiphloiae.

It is nearly allied to Eucalyptus uncinata (Turczaninow, in Bulletin de la Société des Naturalistes de Moscow, 1849, ii. 23), which forms also a constituent of the Mallee-scrubs, but in that Eucalypt each anther cell opens by a minute pore. Eucalyptus oleosa had no claims to be énumerated among the timber-trees of the western colony, but the oil obtainable from its foliage is so valuable and peculiar that this Eucalypt could not well be excluded from the present document. Its oil was among the numerous new technologic articles exhibited by the writer at the second London Exhibition in 1862. Its specific gravity is 0.911 ; it is the best known solvent of amber and other fossil resins and of India-rubber, and has proved unique in many technologic applications.

This tree, though too small for timber, is important for the large yield of oil from its foliage.

\section{Explanation of Lithogram. Plate XII.}

1. Four forms (three abnormal) of the calyx ; 2. Longitudinal section of unexpanded flower ; 3. Front view of stamen; 4. Back view of stamen; 5. Pistil; 6. Three varieties of fruit; 7. Longitudinal section of fruit ; 8. Transverse section of fruit; 9 . Sterile seeds ; 10. Fertile seeds.

14. Eucalyptus longicornis. F. v. Mueller, Fragıenta Phytographiae Australiae, xi. 14 (1878). The Morrell-tree.

It is needless to devote to this Eucalypt a special description, as most probably it constitutes a mere variety of the preceding. It differs, however, in its comparatively tall stature, attaining a height of 120 feet, and perhaps more; the leaves are longer and more lustrous, the stalks and stalklets of the flowers are also longer, and the lid-from which the name "longicornis" became derived-is hornlike-elongated.

On the sources of the Swan River it is interspersed with E. loxophleba and E. salmonophloia, extending thence eastward. It agrees with the York Eucalypt in its bark, with the salmonbarked Eucalypt in its foliage, from which latter it is easily distinguished by the longer and more pointed lid, the elongated style and the evidently larger fruits. The leaves are equally rich in oil, so that probably after E. salubris (which like E. amygdalina yields nearly four per cent. of oil from the fresh foliage), both the Morrell and the Salmon-bark Eucalypt would rank among West Australian congeners next in the yield of this valuable volatile fluid. The oil is obtained in the most profitable manner by passing steam through the foliage in a still.

The wood is nearly as dark as that of E. marginata; it is remarkably hard, and used for rafters, shafts, naves, spokes, harrows, and all kinds of wheelwrights' work. Straight and lasting rails up to twenty-five feet in length can be obtained from young trees.

\section{Explanation of Lithogram. Plate XIII.}

1. Longitudinal section of flower bud; 2. Anterior view of stamen; 3. Posterior view of stamen; 4. Style with stigma; 5. Longitudinal section of fruit; 6 . Transverse section of fruit; 7 . Sterile seeds; 8. Fertile seeds; 9. Embryo; 10. Cotyledons pressed outward, to lay free the radicle; 11. Elongated flower buds of a variety with longer stalklets.-All analytic details, except 11, magnified. 
15. Eucalyptus salmonophloia. F. v. Mueller, Fragmenta Phytographiae Australiae, xi. 11 (1878). The Salmon-barked Eucalypt.

Leaves scattered, of rather thin consistence, sickleshaped-lanceolar, shining and equally green on both sides, copiously dotted with pellucid oil-glands; the veins concealed, the peripheric vein but little removed from the margin; umbels axillary, solitary, with few or several flowers; stalklets very thin, nearly three times shorter than the almost cylindric flower-stalk, but about as long as the semiovate tube of the calyx; lid semiovate-conical, slightly exceeding the length of the tube; stamens very short and all fertile; the outer filaments flexuose-erect before expansion, the inner ones inflexed while in bud; anthers cordate- or renate-globular, bursting by longitudinal slits; fruit small, semiovate, three- or rarely four-celled; valves long-exserted, very narrow and pointed; seeds minute without any appendage.

From the upper regions of Swan River, as far as the vicinity of Victoria Springs, occurring in interrupted patches.

This tree attains a height of about 100 feet. The grey and slightly-purplish smooth bark is of an oily lustre, which characteristic has suggested the vernacular name of the tree. Of the quality of the timber not much is known; it has furnished, however, good fence-wood. Here it was deemed desirable to allude to the tree, because it is one of the few in West Australia yielding on distillation a large quantity of oil from the foliage. The export of the seeds of this species and of those of any other kinds rich in oil may become important, as these Eucalypts are so much sought to subdue malarian evaporations. The nearest affinity of the Salmon-barked Eucalypt is to E. oleosa, but it differs in its entirely smooth bark, the smaller flowers and fruits, and the shorter and also blunter lid of the calyx.

\section{Explanation of Lithogram. Plate XIV.}

1. Longitudinal section of flower bud; 2. Lid of calyx removed to show the direction of the outer stamens; 3. Front view of stamen; 4. Back view of stamen; 5. Pistil ; 6. Longitudinal section of fruit; 7. Transverse section of fruit; 8. Sterile seeds; 9. Fertile seeds; 10. Embryo; 11. Cotyledons bent to exhibit the radicle.-All analytic figures magnified.

16. Eucalyptus salubris. F. v. Mueller, Fragmenta Phytographiae Australiae, x. 54 (1876). The Gimlet-wood or Fluted Eucalypt.

Leaves scattered, sickleshaped-lanceolar, on both sides equally green and very shining, perforated by very copious oil-dots; the veins ascending in a very acute angle, the peripheric vein but little distant from the margin; umbels axillary, solitary, few-flowered; stalks linear-cuneate, very compressed; stalklets as long as the semiovate tube of the calyx or up to twice as long; lid semi-ellipsoid, very blunt, twice as long as the tube of the calyx; stamens inflexed before expansion, ali fertile; anthers oval-oblong, dehiscent along the margin, their two cells separated in their whole length by a broad connective; fruit small, semiovate, three- to four-celled; valves short, deltoid, emersed; seeds without appendage.

From the upper Swan River extending as far as the Victoria Springs, where it was first met in Giles's expedition, forming small forests in various places. Its further distribution remains hitherto unascertained.

This tall but slender tree is remarkable for the broad longitudinal often twisted impressions or roundish blunt longitudinal ridges of its stem. The bark is smooth, shining, and of a brownish tinge. The length of the stem up to the first branch reaches not rarely 100 feet. The wood serves for poles, shafts, rails; although tough it is worked with comparative ease ; it is harder and paler than Morrell-wood, and proves to me the best of all for wood-engraving known from 
West Australia. The extraordinary abundance of oil in the leaves, approximately four per cent. in the fresh foliage, points this species out as the leading one in West Australia for oil distillation, its yield in this respect being as rich as that of Euc. anygdalina of Victoria, Tasmania, and New South Wales, many thousand pounds' worth of that oil having been exported from Melbourne from Mr. Basisto's factory.

\section{Explanation of Lithogram. Plate XV.}

1. Calyx of two varieties, natural size; 2. Operculum moved from the calyx-tube to exhibit the stamens while in bud; 3. Longitudinal section of unexpanded flower; 4. Front view of anther; 5. Back view of anther; 6. Pollen grains, 250 times diametrically enlarged; 7. Pistil; 8. Longitudinal section of fruit; 9. Transverse section of fruit; 10. Sterile seeds; 11. Fertile seeds; 12. Embryo; 13. Cotyledons torn asunder to lay free the radicle; 14. Portion of leaf showing venation and oil-dots.-All details, except 1, magnified.

17. Eucalyptus angustissima. F. v. Mueller, Fragmenta Phytographiae Australiae, iv. 25 (1863). Bentham's Flora Australiensis, iii. 238.

Leaves rather small, scattered, broadly linear, thinly acuminate, on very short stalks, equally green and shining on both sides, perforated by very numerous oil-dots; the veins almost concealed; flowers from two to four on short axillary, solitary, almost cylindric stalks, and provided with only very short stalklets; lid semiovate or somewhat conical, nearly twice as long as the hemispheric not angular tube of the calyx, and slightly narrower; stamens inflexed before expansion; anthers minute, almost heart-shaped, opening by longitudinal slits; fruits very small, almost hemispheric, three- to four-celled, slightly contracted at the convex rim; valves deltoid; seeds without appendage.

On the western side of the Great Bight, discovered by Mr. Maxwell.

The precise geographic limit of this Eucalypt remains as yet unknown; it belongs probably to the tertiary limestone formation, and may thus have a very extensive range. It is allied in many respects to E. salubris, but the flower stalks are not dilated, while the leaves are narrower than in any other Eucalypt.

The species, though mostly of shrubby growth, has found a place in this document in order to draw attention to the copiousness of its volatile oil, more especially as various sorts of Eucalyptus produce considerably different oils, and these not alike available for special technic purposes.

Only a shrubby species, but peculiar to West Australia, and structurally remarkable.

Explanation of Lithogram. Plate XVI.

1. Longitudinal section of unexpanded flower; 2. Front view of stamen; 3. Back view of stamen; 4. Style with stigma; 5. Longitudinal section of fruit; 6. Transverse section of fruit; 7. Seeds. - All magnified.

18. Eucalyptus megacarpa. F. v. Mueller, Fragmenta Phytographiae Australiae, ii. 70 (1860).

Bentham's Flora Australiensis, iii. 232. The Blue Gum-tree of West Australia.

Leaves scattered, sickleshaped-lanceolar, of firm consistence, the veins subtile and hardly prominent, the peripheric vein but slightly removed from the margin; flowers one to three, often two, large, axillary, sessile on a thick and very compressed stalk; tube of the calyx turbinate, not angular, with a prominent margin; lid smooth, hemispheric, pointed; stamens all fertile, inflexed before expansion ; anthers oval-oblong, opening with parallel longitudinal slits ; fruit truncate-globular, large, four-to six-celled, with convex and not channelled rim ; valves emersed ; seeds angular, shining, without any appendage.

Sparsely occurring from the vicinity of King George's Sound to Cape Leeuwin, occasionally ascending the tops of mountains.

This tree is very different from the celebrated Blue Gun-tree of Tasmania and Victoria-namely, Eucalyptus globulus - never attaining the enormous size of that species, seldom, indeed, exceeding 100 
feet in height, differing also much in its floral characters and in its fruit. The bark is smooth, hence E. megacarpa ranks among the Leiophloiae. Of the value of the timber almost nothing is known. The specific name is derived from the comparatively large size of the fruit.

19. Eucalyptus pyriformis. Turczaninow, in Bulletin de la Société des Naturalistes de Moscow, 1849, ii. 22. Bentham's Flora Australiensis, iii. 226.

Leaves scattered, of thick consistence, oval-lanceolar, acuminate, with spreading parallel very fine veins, the peripheric vein slightly distant from the margin, the oil-dots hardly visible; flowers very large, one to three together on thick cylindrical finally recurved and often elongated stalks; calyx red, its tube semiovate, with two to four prominent angles, tapering into conspicuous stalklets; lid semiovate-hemispheric, short pointed, nearly as long as the tube of the calyx; stamens inflexed before expansion, all fertile; anthers ovate-cordate, opening by parallel longitudinal slits ; fruit of very large size, hemispheric-turbinate, two- to four-angled, four-to six-celled, the broad rim ascending from the concave edge; valves enclosed; seeds without appendage.

This highly remarkable species has found a record here not as a timber-tree (for it is mostly of shrubby growth), but as deserving culture for ornamental purposes, its red calyx and long stamens being showy conspicuous.

The shape and size of the calyx gave rise to the specific name. Several other large-flowered Eucalypts are peculiar to Western Australia, for instance : E. macrocarpa (Hooker), E. Preissiana (Schauer), E. tetraptra (Turczaninow), E. ptychocarpa, E. erythrocorys, and E. Voungiana (F. v. M.), the seeds of all which could be made an article of commerce.

This is only a shrubby species, but as it is much sought in horticulture on account of its red calyx it is well worthy to be included in the West Australian Eucalyptus Atlas, the sale of the seeds being an industrial resource.

\section{Explanation of Lithogram. Plate XVII.}

1. Transverse section of unexpanded flower ; 2. Front view of stamen ; 3. Back view of stamen ; 4. Style with minute stigma; 5. Longitudinal section of unripe fruit; 6. Transverse section of young fruit ; 7. Sterile seeds ; 8. Fertile seeds.-All enlarged.

Besides the species enumerated several other Eucalypts pass inWestern.Australia under vernacular names-thus Eucalyptus patens (Bentham) is the Blackbutt-tree there; the Spearwood is E. doratoxylon (F. v. M.) ; the Yatthae is E. foecunda (Schauer); while several well-defined tropical species pass as Bloodwood-trees, Stringybark-trees, Box-trees, \&c.

With the economic properties of these species we are as yet almost macquainted.

\section{B.-Timber Trees not Eucalypts.}

It may suffice to offer merely cursorily some notes without descriptions on the other principal trees of technic value, occurring in West Australia, not belonging to the genus Eucalyptus. Among them the Casuarinas are for wood perhaps the most important.

Casuarina Fraseriana (Miquel) yields there one of the most elegant furniture woods and a splendid and extensively used material for shingles.

Casuarina glauca (Sieber) is one of the interior desert-trees of considerable size; the wood is hard and durable.

Casuarina Decaisneana (F. v. M.) is the Central Australian species, which enters the remote eastern portion of the colony. The few other tall congeners are of less importance, although every one of them furnishes excellent fuel. 
Agonis flexuosa (Schauer). The Peppermint-tree of many of the river banks and humid valleys. Attains a height up to seventy feet. Wood sought for various implements, and also for superior fuel.

Melaleuca Leucadendron (Linné). The tropical Paperbark-tree. On river banks in the intra-tropical districts. The tree attains 100 feet in height, or more, and can be planted on wet saline ground, even on tidal streams. The hard wood resists the white ants, and is available for many kinds of building purposes and various artisans' work, also for shipbuilding. Several species of very tall Melaleucas pass in the extra-tropic districts as Paperbark-trees, and their wood may perhaps prove as valuable as that of the northern species. They are all important for subduing malaria in swamps even of brackish water.

Frenela verrucosa (Cunningham). This is the most widely-distributed Cypress Pine of Western Australia, valuable for its splendid wood and also for its resin, which is very similar to the Sandarac from the Callitris Pine of Northern Africa.

Banksia verticillata (R. Brown). The River Banksia of West Australia, confined to moist valleys. It rises to seventy feet or even more. The beautiful pale and soft wood is sought by joiners for furniture, sashes, and many other purposes, for which otherwise deal is used. The other congeners, which form good-sized trees in West Australia, are Banksia littoralis, B. attenuata (the narrow-leaved Banksia), B. Menziesii, B. ilicifolia (the prickly Banksia), all named by R. Brown, and B. grandis (Willdenow).

The species on the North-West coast is B. dentata (Linné).

Santalum cygnorum (Miquel). From the vicinity of the great Bight to Shark Bay. The fragrant Sandal-wood of West Australia, which for many years past has been so largely exported, is derived from this species.

Acacia acuminata (Bentham). The raspberry-scented Acacia. A small tree widely-distributed through extra-tropic West Australia. It yields lasting fence-posts, though its scented and hard wood should realise a good export price for ornamental wood-work, on account of its fragrance. It furnishes the best of charcoal in West Australia.

Acacia saligna (Wendland). A small tree, common in most parts of extra-tropic West Australia, at least towards the coast. Its bark is as rich in tannic acid (up to thirty per cent.) as that of Acacia decurrens, A. pycnantha, A. falcata, and A. harpophylla in East Australia. It is easily and quickly raised from seeds, even on poor sandy ground.

Acacia microbotrya (Bentham). The Badjong Acacia. This species yields an enormous quantity of superior gum, according to Mr. George Whitfield, sometimes as much as fifty pounds weight from a single tree.

Several other Acacias produce in West Australia fragrant wood, tanners' bark, and mimosa gum, but which precise species is as yet not well known, more than 150 Acacias standing already on record from the hitherto explored portions of the Western Australian territory, although the majority of them are shrubby kinds. The seeds, however, of every sort would be acceptable for horticultural export trade, Australian Acacias being always in request for European glass-liouses, to aid in a display of very early spring-flowers and odd foliage in conservatories. Very few of the West Australian species are as yet under cultivation. 


\title{
II.-CHEMICAL AND MICROSCOPICAL EXAMINATION OF
}

\author{
EUCALYPTUS-WOOD.
}

Conspicuous ingredients of Eucalyptus-wood, irrespective of such as are found in all other kinds of timber, are Kino-tannic acid, which readily dissolves in water and alcohol, and Phlabaphen or a closely allied pigment, only soluble in alkaline liquids, and re-precipitable on neutralisation by acids. The comparatively large development of phlobaphenic pigment has on this occasion been demonstrated in the wood of Eucalyptus marginata and Eucalyptus rostrata; and it is a significant fact, that just these two kinds of wood more than any other among the Eucalypts resist decay by antiseptic ingredients for long periods, when immersed in soil or water, or when otherwise exposed to disintegrating influences. This peculiar form of Phlobaphen seems to owe its origin to changes produced in the tannic acid. The pigments contained in Eucalyptus diversicolor, E. longicornis, E. calophylla, E. loxophleba, E. salubris, E. cornuta, and also E. globulus (which were the only kinds of wood subjected at present to comparative experiments in this respect) are chemically indistinguishable, so far as the tests went, but differ in some optical characters, as observed by Mr. L. Rummel, who has ably aided me in these microscopic and chemical investigations. In all probability the Phlobaphen is elaborated from the tannic sap, and deposited gradually while the new growth of wood matures; hence it is most richly stored up when the main activity of the circulation has ceased. It is not merely on account of the diminished humidity contained in the wood at the end of the dry season, or at the annual termination of its cyclus of life, but also in consequence of the phlobaphenic substance having then become fully elaborated with other elements of the mature wood, that timber wili prove in the highest degree durable, when felled towards the end of the summer, before heavy autumnal rains start the circulation anew for another year's growth. I am aware that it is at present beyond possibility to restrict at large colonial sawmills the operations for cutting trees to a very limited period of the year; still such timber, as is needed for exceptional purposes of resistance, should be secured during the late summer months. Whether to this generally recognised rule any exceptions exist in Western Australia-be it from climatic circumstances or from special peculiarities of the timber there-can only be ascertained by local test and experience, for which no opportunities have arisen to myself.

It is likely also, that the durability of the Eucalyptus-wood may partially depend on the quantity of oleo-resin, bitter of taste and soluble in alcohol, by which it is more or less pervaded. To fix the respective quantity of this oil-resin of various Eucalyptus-woods must remain the object of subsequent researches, no time being allowed to enter on a set of investigations of this kind for the present document.

In Eucalyptus marginata the phlobaphenic particles fill up as a brown and pellucid mass the cavities of most of the vascular and cellular tissue, at least in the harder kinds of wood of that species, which is obtained from mountain regions. In the lighter and softer kinds of Yarrah-wood the Phlobaphen occurs in far lesser 'quantities. In Eucalyptus rostrata both vascular and celullar cavities are very extensively filled with the phlobaphenic substance; in the other kinds of wood subjected to examination for this Report, the Phlobaphen occurs chiefly in the vascular tubes and fills them far less completely. 
TABLE.

In 100 parts of Air-dried Wood of

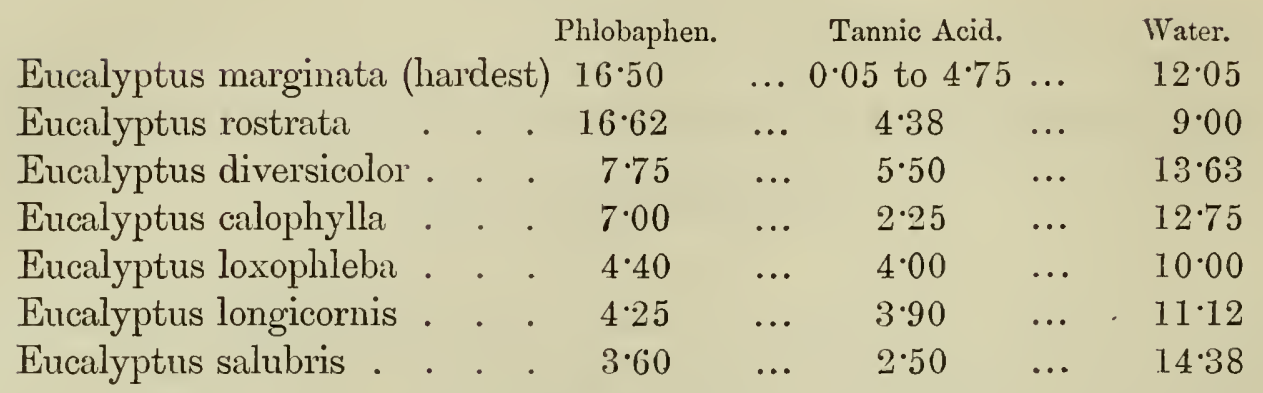

The results rest, however, on solitary analysis only except in reference to the Phlobaphen of Eucalyptus marginata, where the average of three tests is given.

The West Australian Eucalyptus-woods, when dried, vary very considerably in specific gravity. Those of Eucalyptus cornuta, E. loxophleba, E. salubris, and E. longicornis sink in water at once; that of the harder kind of E. marginata and those of E. calophylla, E. diversicolor, and E. rostrata sink only after soaking; that of the lighter kind of E. marginata remains lighter than water under any circumstances.

\section{Specific Gravity of Air-dried Wood, ascertained by the IIydrostatic Method.}

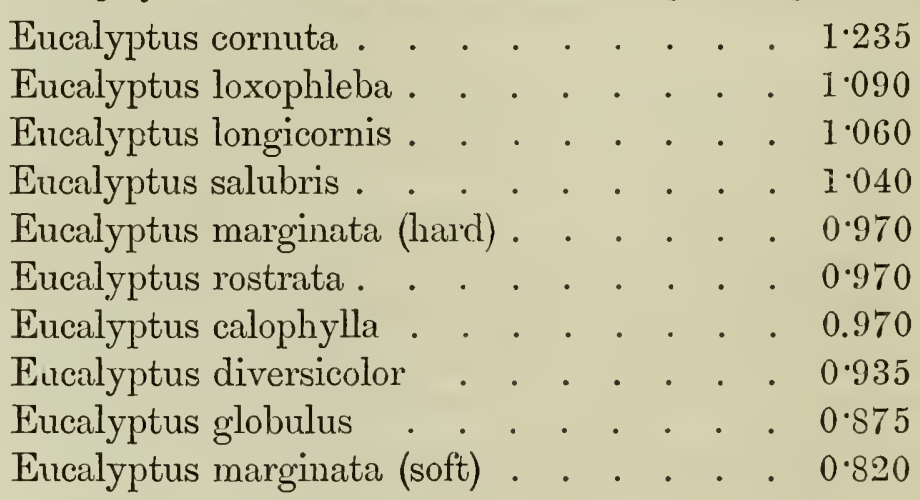

The vascular tubes of each kind of Eucalyptus-wood vary in size within certain limits; they are, however, always very much larger and consequently always much less numerous in $\mathrm{E}$. marginata, E. diversicolor, E. longicomis, E. calophylla, and E. rostrata (also E. globulus), than in E. loxophleba, E. cornuta, and E. salubris.

The woody fibre (Prosenchyma or Pleurenchyma) is remarkably different in reference to the thickness of its walls, and the lumen of its cavity in different kinds of Eucalyptus-woods. In E. cormuta, E. salubris, and E. longicornis, the cavity is very small in proportion to the thickness of the walls; that of $\mathrm{E}$. cornuta is the narrowest of all, the lumen being many times smaller than the walls. In E. marginata the width of the cell of the ligneous fibre is variable, according to different sorts of wood, but it is never so wide as in E. rostrata (and also E. globulus), but about the same diameter as in $\mathrm{E}$. diversicolor. Intermediate in this respect between the above-contrasted species are E. loxophleba and E. calophylla. These observations need repetition on ampler material.

The cellular substance (Parenchyma) is more or less copiously distributed throughout the mass of the wood in various Eucalypts, and more generally developed around the vascular tubes. Its cells have usually about the same diameter as the ligneous fibres, but their walls are thinner. In the light kind of wood of E. marginata, in E. globulus, and E. calophylla, the diameter is larger than that of the Prosenchyma. How far this will prove constant in wood of different ages and from distinct 
localities remains to be ascertained. The wood of $\mathrm{E}$. salubris is remarkable for the comparative paucity of its Parenchyma-cells, their number being six times less than in E. calophylla and E. loxophleba.

The medullary rays in all the West Australian Eucalyptus-woods, subjected to examination for the present purpose, consist usually of no more than two rows of cells; in E. rostrata medullary rays of three series occur. The breadth of the medullary rays, as a rule, decreases in proportion to their distance in various kinds of these woods; the width of single rows is generally greatest in E. diversicolor and narrowest in E. salubris.

In conclusion, it may be summed up that the capability of different kinds of Eucalyptus-wood to endure for lengthened periods the destructive contact with humidity, air, and temperature depends largely, and perhaps mainly, on phlobaphenic substance unchangeable by water ; further probably also on the occurrence of oleo-resin, on the reduced number of hollow vascular tubes, on the organisation of the walls of the ligneous fibre, on the decreased copiousness of parenchymatic substance, and on the lesser space occupied by the medullary rays. The hard variety of Yarrah-wood fulfils most of these conditions, eminently so of the first one, and the same may be said of E. rostrata. It must, however, be remarked that nearly all the above observations, as here now instituted, refer only to solitary samples of wood, whereas it is but reasonable to suppose that wood from different trees or portions of trees, even of the same species, when grown in different soils and climes, would vary in some respects; nevertheless it is likely that the relative superiority of one sample of Eucalyptuswood over another would always clearly and instantaneously be demonstrated by the aid of the microscope and according to recognised chemic and anatomic principles, which continued experimental research is likely to affirm as reliable.

\section{III.-CULTURAL MEASURES TO ENRICH THE WEST AUSTRALIAN FGRESTS.}

Although the colony is so very rich in durable hard woods, it is nowhere extensively endowed with trees of the soft wood classes, and it is almost totally devoid of timber which could readily be utilised instead of deal, red cedar and many other kinds of easily workable wood, such as are in daily demand by artisans. Indeed, every country should strive to place itself, regarding timberresources, in a position of independence, so far as climatic circumstances will permit; and in this respect West Australia is most happily situated, its wide territory, stretching through twenty-two degrees of latitude, admitting in reality of the culture of almost every kind of utilitarian tree in existence anywhere.

West Australia possesses three principal or extreme climatic regions, though through mary tracts they verge into each other:-

A. The humid cool forest-country.

B. The dry regions, particularly inland.

C. The tropical coast-tracts.

All three demand foreign trees and other cultural plants, selected purposely for each.

A. In the southern forest regions, where Yarrah- and in some districts Karri-trees prevail, all kinds of utilitarian plants, requiring a comparatively cool and humid atmosphere, should be brought under test with a view to final selection from them for culture and naturalisation. The renowned Wellingtonia- and Sequoia-pines, which in their colossal dimensions exceed even the Karri-Eucalypts, the Oregon-pine (Pinus Douglasii), the great Silver-fir (P. grandis), the lofty Sugar-pine (P. Lambertiana), Menzies'-pine, the yellow Pitch-pine (P. ponderosa), which with Pinus Sabiniana and 
P. Lambertiana produces edible nuts, and the Nutka-cypress, all from North-Western America, could be reared for pine-timber in the forest-tracts between Swan River, Cape Leeuwin, and King George's Sound. It is also there, where the Weymouth-pine (Pinus strobus) which yields us mainly the white deal of the eastern United States, the two principal American Pitch-pines ( $P$. australis and P. rigida), the white Cedar-cypress, the Thuya occidentalis, the Virginian Swamp-cypress (Taxodium distichum), and many others of the fir-tribe from eastern North-America, would find their place. The Lebanon-cedar with its Himalayan Deodar-variety, the Bootan-pine (Pinus excelsa), the Cheer-pine (P. longifolia), the Dye-pine (P. Webbiana), the Nepal Nut-pine (P. Gerardiana), with many other Asiatic species, the tall Nepal-cypress (Cupressus torulosa), then the Silver-fir of Middle Europe (Pinus Abies), and the Norway-spruce (P. Picea), would also in the Yarrah-and Karri-forests rapidly attain a great height.

To these ought to be added, so far as coniferous trees are concerned, all kinds of Kauris, especially that of New Zealand, chiefly for masts and spars, the Totara or Mahogany-pine of the same islands, the various kinds of Larches (in the coolest places), the Sugi (Cryptomeria), the Hinoki (Cupressus obtusa), the Thuyopsis, the Gingko of incalculable longevity-the four last-mentioned from Japan, the Gingko being there the grandest of all-the Pencil-cedars (Juniperus bermudiana, J. virginiana, J. chinensis), with some other congeners should, as highly desirable, not be passed on this occasion, nor the nut-bearing Araucarias of Brazil and Chili, all important for yielding pinetimber. The Norfolk Island and the Moreton Bay Araucarias, of which A. Bidwilli further yields edible nuts, are established at many West Australian domiciles already, and could advantageously be grown in West Australia as forest-trees.

Among trees not coniferous might be introduced into the most south-western forests large numbers of the best of Oaks, particularly the White Oak (Quercus alba), the best of all for coopers' use and highly important for shipbuilding, the Burr Oak (Q. macrocarpa) and the Live Oak (Q. virens) of North America; also the British Oak, and numerous other species, either evergreen or deciduous, from both hemispheres. The Cork Oak (Q. Suber) and the Valonia. Oak (Q. Agilops) would also thrive best in these forest regions, although they might be planted as well in drier localities for bordering roads and streets. Speaking of avenue-trees, I may be permitted to observe that one of the most splendid among those of evergreen verdure which can be chosen is the tall Grevillea robusta of East Australia, which vies with the Nuytsia in the brilliancy of its flower, but surpasses it far in the ease with which it is reared and in the excellence of its timber. The ordinary Walnut-tree, as well as the North American Butter-nut and Black Walnut-trees, and the allied Hickories (Carya alba, C. glabra, C. microcarpa, C. tomentosa, C. sulcata, and C. oliviformis) are all recommendable for transfer to the West Australian forests on account of the excellence of their peculiar wood, irrespective of the value of their fruits, those of the Shellbark Hickories (Carya alba and C. sulcata) and of the Pecan-nut (C. oliviformis) rivalling the European Walnuts. The evergreen Nut-tree of East Australia (Macadamia or Brabejum ternifolium) together with the allied Chilian Hazel (Guevina Avellana) should mingle as denizens of the southern forest-trees of Western Australia. The hardiest Indiarubber-tree (Ficus elastica) deserves also introduction there. It is in the south-western forests also where large plantations of the hardy Red Cedar of East Australia and India (Cedrela Toona) and likewise that of South America (Cedrela brasiliensis) should be reared for one of the best and most easily worked of furniture woods, which from the exhausted "Cedar brushes" will ere long be no more obtainable. The Sweet Chestnut-tree deserves the fullest attention both for its timber and its nuts, whether in forest land or for shading roads or streets. The North American Sugar Maple with many of its congeners, as well as some of the best Ash-trees from both hemispheres, could also advantageously be introduced into the forests of West Australia. It would be easy enough to transfer Beeches, particularly the beautiful evergreen species of East Australia, Tasmania, and New Zealand, to the banks of watercourses in the Karriforests, if their wood was deemed requisite. The Blackwood-tree of South-East Australia (Acacia melanoxylon) deserves special attention for the sake of its magnificent wood, which for furniture, 
as well as for carriage- and boat-building, staves, \&c., has come most extensively into use ; its bark moreover contains as much as twenty-eight per cent. of tannic acid.

Though West Australia is so rich in Eucalypts, yet the East Australian E. citriodora might well become an inmate of plantations there on account of the exquisite fragrance of its foliage and the essential oil to be distilled therefrom. Hazels, Filberts, Bamboos, Poplars, and Osier-willows (among the latter especially Salix purpurea, S. rubra, S. viminalis, and S. triandra) set quickly a barrier to bush-fires, if planted along rivulets; the last-named yield simultaneonsly the most valuable products for basket manufacture, the best charcoal for gumpowder, and the medicinal salicine. Concomitant with tree culture the formation of tea-plantations could proceed in all the south-western forest valleys, as the Chinese (or rather Assam) Tea-bush would prove quite hardy, and in the humid valleys particularly prolific also. The simplified processes in preparing the young leaves (as pointed out in a printed essay of mine from recent Upper Indian experiences) would render tea-culture in the Yarrah- and Karri-forests most remunerative, and could afford occupation to the juvenile and infirm among the labouring classes, as would in irrigated valleys the culture of the Hop-plant. The Turkish Box-tree also, the wood of which cannot be fully replaced by that of any other tree for xylography, is likely best developed to the requisite dimensions in the forest-land, wherever the soil contains a considerable quantity of lime. Even the Peru Bark-trees (Cinchonas) would adapt themselves to these sheltered and equally temperate regions, they having flowered in Victoria as far as $38^{\circ} \mathrm{S}$. unprotected.

The Rhea- or Ramee-fibre '(from Boehmeria nivea) and similar textile material from some allied bushes of the genera Debregeasia, Maoutia, Pipturus, Villebrunia, and Tonchadi, all preferring a moist clime, could also best be produced in the forest-valleys.

An essay of mine on such fibre-plants, as are adapted for extra-tropic Australia, appeared in print a few years ago. Quite a legion of forest-grasses from different parts of the globe might likewise be easily disseminated through these sylvan regions. Among the latter I would merely single out Bromus asper, Festuca gigantea, Melica nutans, Milium effusum, and Poa nemoralis, as among the English species, the gigantic Festuca dives of Victoria, which when once raised would be sure to spread on its own accord through all the moist portions of the woodlands. Similarly the still more nutritious Prairie-grass (Bromus unioloides) should be dispersed. The Falkland-island Tussock-grass may live in the coldest sandy heath-moors.

It is beyond the scope of this document to adduce all the most important plants from which new treasures could be obtained in the genial forest-clime of West Australia, but while referring for further information to my work on "Select Plants," I will conclude this passage by merely pointing out yet, that a multitude of forest fruits, such as the British Bilberry (Vaccinium myrtillus), the Canadian large Cranberry (V. macrocarpum), the Blueberry (V. pennsylvanicum), some Gaylussacias, and the Blackberries (among them the North American Rubus occidentalis, R. macropetalus, R. canadensis, R. villosus, R. trivilis) could with very little care and expenditure be naturalised along the forest-brooks with species of Rubus and Fragaria. By the mere scattering of the dust-like spores of fern-trees (among which the South-East Australian Dicksonia antarctica and Alsophila australis and the New Zealandian Cyathea dealbata and C. medullaris are grand and graceful in the extreme, the magnificent featuris of these noble productions of Nature could without the slightest difficulty in the course of time be impressed also on the forest-valleys of West Australia, to enhance the scenic beauty afforded by indigenous palm-like Zamias, which latter ought to become lucrative articles of export to conservatories abroad. In and out of the forests many hardy Palms, Bamboos, and also the various Yuccas, Fourcroyas, Agaves, Dasylirions, together with the New Zealand Palm-lilies (Cordylines), could be introduced into the landscapes cheaply and copiously for embellishment and scenic effect. Seeds of the Palm-lilies obtainable already millionfold from plants, reared by me around Melbourne, when merely thrown broadcast on open places at the forest-ravines, would raise these elegant forms of palm-like vegetation not merely for decorative grandeur, but also for the textile fibres of their foliage. The superb Rice- 
paper bush of Formosa could from hence furnish irrespectively its pith for solar hats. For the dissemination of truffles and the best of mushrooms forest ground is also always the most favourable, and efforts might be made for their introduction, when an insight into the manner in which these selfcaring vegetables can be transferred to wide distances shall have been obtained.

When so many indications of the mildness of the West Australian climate are obtained, the wish cannot be suppressed to see the Chinese Date-plum or Kaki, regarded as the most delicious of all the fruits of Japan, associated with the colonial table-fruits. The North American Persimon, a congener of the Kaki, is a much hardier tree. None of the splendid Guavas seem as yet represented in the colony, nor the best of Passion-fiuits or Granadillas; Passiflora ligularis is noted as one of the finest fruits anywhere in existence at Caracas, while in the Botanic Garden at Brisbane fruits were obtained from Passiflora macrocarpa weighing eight pounds. The Rena of Fiji, the Tongan and Society-islands (Spondias dulcis) ranks also as an important tree, yielding esculent fruits in copiousness. Nor has the South American Cherimoyer found its way to Western Australia, nor other Anona trees with edible fruits, nor the Sapodilla plum, nor the Chinese Hovenia and Litchi ; many of these would thrive best in forest-lands. My work or "Select Plants," the re-issue of which for wide distribution in West Australia seems recommendable, gives fuller information also on this subject.

In West Australia the forest-fires are not so excessively destructive as in the eastern colonies, nor do they as there leave in ghastly deadness vast numbers of standing trees, after the burning element has swept through the woods; on the other hand, the woods of West Australia are charming at all times, no lifeless trees disfiguring the landscape, all fresh and ever verdant with Zamias, Xanthorrhoeas, and Kingias remaining unimpaired by the scorching flames. Nevertheless, the bushy vegetation and underwood, and all kinds of herbaceous plants, are at least periodically apt to be annihilated in the woody country, when the bush ignites; hence the same precautions, which are recommendable in the other colonies to interrupt the fires, must be adapted also in the Yarrah-and Karri-forests, to prevent the destruction of foreign plantations formed within their shelter or limits; watercourses, or bands of soil turned up by plough furrows, or stone-lines, where rocks or boulders are readily accessible, will often debar fire from ingress ; or it may become advisable to border plantations of select value by any kind of vegetation not inflammable or not readily consumed by ignition. To plants fit for this purpose allusion has already been made; and in the same manner as for streetavenues or for road-lines such trees should have preference as will yield annually a return in utilitarian products, so also for these forest-fences, besides rows or copses of Mulberries, can be adapted many kinds of Blackberry bushes, Roses for Attar-distillation, and an almost infinite number of other productive plants fit to be reared into hedges.

B. The dry inland regions of West Australia, though possessing naturally little forest-timber, should not beleftout of consideration in this recommendative Report, and should also be brought within the scope of forest surveillance. The more or less open or bushy land, whether belonging to the limestone, granitic, or sandstone formation, or to any other geologic age, offers howerer only a limited range for the choice of plants suitable for culture; but in proportion to the wide extent of these dry tracts of country stands also the importance of those plants, by the cultivation or natural dispersion of which such lands may be ameliorated and rendered infinitely more productive for pastorai and even sometimes for agrarian pursuits. A regularly organised forest administration of the colony must take charge also of these districts; and here the watchfulness of the forest department will be all the more needed, inasmuch as at least the present desert-area is for long periods not likely to be alienated from the possession of the Crown; yet even these desert-lands will afford ample scope for raising there not only woods, but also many other utilitarian plants, to enhance the public revenue gradually with but little original outlay. Pines again claim here, in a very high degree, our attention. In the southern districts, at least, several firs will endure perfectly well the dry slime, among them the Cluster-pine (Pinus Pinaster), the Stone-pine (P. Pinea): the common 
Seacoast-pine (P. halepensis), all three from the countries bordering the Mediterranean Sea ; further, the famed Pinus insignis from California (first introduced into Australia, and most copiously too, by the writer of this document), which, indeed, is the most rapidly-growing of all pines of the globe, and yet at the same time one of the most regardless to soil; all these, together with the gigantic and quick-growing Cupressus macrocarpa of California, can be raised even on the sands of the sea-coast, which will thus finally be converted into pasture-land. How far northward these firs would prosper in Westem Australia remains yet to be ascertained. For several other coniferous trees, fit for dry and poor ground, I would refer to the "Select Plants."

In altogether timberless localities, at least in the more southern latitudes, no tree could be more quickly and easily raised for shelter, fuel, and hardwood-timber than the celebrated Blue Gum-tree of Tasmania and Victoria (Eucalyptus globuius). Very special allusion deserves a tree from the eastern colonies, the Acacia decurrens, for obtaining within a few years a revenue from very sterile land. This, the feather-leaved Wattle, attains a much greater height, grows with more rapidity, and produces a larger return of the richest tanners' bark, than any West Australian Acacia. It is here, however, not recommended as a timber-tree, although its wood serves for staves and various implements. This tall Wattle exudes also gum of mercantile value rather copiously. For Olive culture porous calcareous soils towards the sea-coast are best adapted, though these long-living trees of great fecundity are able to cope even with protracted drought.

But it is more particularly the grasses to which I wish to turn, for showing that through their. gradual progress the most arid tracts of country can be rendered habitable. We have witnessed already what a marvellous effect the Cynodon Dactylon or Doab or Doorva grass, passing in West Australia as Couch grass, has already produced on some of the sand-lands of the colony; but in the same manner the Stenotaphrum americanum, called in Australia Buffalo grass, would operate there to subdue the worst of drift sand and cover it with lasting verdure. According to locality and soil various grasses of the genera Agrostis, Alopecurus, Avena, Chloris, Dactylis, Ehrhairta, Eragrostis, Festuca, Lolium, Phleum, Melica, Poa, and in poor localities especially the best kinds of Andropogon and Panicum should be dispersed, as they are evidently destined, particularly the perennial species, to give nutritive pasture even to extremely arid and sandy tracts, if the dissemination is aided by the simplest means. Many large Andropogons and Panicums especially resist scorching hot winds in a remarkable degree, and will live on poor sand-land. Attention has also recently been called to Aristida prodigiosa as an important desert-grass from West Africa. Paspalum notatum from the Laplata-stream luxuriates there particularly on somewhat saline ground as a nutritive fodder-grass, whereas P. distichum of East Australia and South Asia is splendidly adapted to line watercourses and surround swamps with an exquisite verdure of turfy grass. The tall and fattening Sorghum Millets, and the Bairee (Pennisetum typhoideum) have also not yet found their way sufficiently widely through the colony. Special mention deserve the best Millet-grasses, such as the Coapin (Panicum spectabile), the Deccan-grass (P. frumentaceum), the Para-grass (P. molle), the Guineagrass (P. maximum), but they need rich soil, and can also be introduced into open places of forest. land for pastoral gain. A most promising huge saccharine fodder-grass, the Euchlaena luxurians of Mexico, has recently come into notice, seeds of which have been sent also by the writer to the western colony.

What holds good for recommending these grasses applies with equal force to a multitude of fodder-herbs. Lucerne and various kinds of Clover (the Alsike-clover succeeding where the ground is too humid for Lucerrie) ought to change the aspect of many. parts of West Australia in years to come, and are likely destined to increase vastly the productiveness of numerous pastures there. Wherever the limestone formation exists, or where otherwise the soil is calcareous, many others of the leguminous fodder-herbs would thrive well, such as the Sainfoin, the Horseshoe Vetch (Hippocrepis comosa), the big Soola-clover (Hedysarum coronarium). The Fagopyrums are also easily dispersed over sand-land to raise the first vegetation. To swampy lands the tall Sesbanias, indigenous also in Northern Australia, can easily be brought for 
naturalisation, cattle being ravenously fond of these so-called wild pea-bushes. They furnish moreover the Dandri-fibre. Accounts of the extraordinary value of the Prickly Comfrey (Symphytum asperrimum) of the Caucasus are perhaps somewhat exaggerated; but in moist, or perhaps even moory soil, not easily otherwise utilised, this fodder-herb may prove of signal importance. Sumach and Scotino, for select dye and tanning purposes, can be reared also on comparatively dry ground. The Date-palm and the ordinary Fig-trees could never be planted in too large a number in the desert-regions. In calcareous soils of the less arid districts the culture of the Carob-tree of the Mediterranean regions (Ceratonia Siliqua) should be initiated and extensively encouraged, the saccharine pods being far more important as fattening fodder than the recently so much lauded Prosopis-beans. The growth of the Ceratonia however is slow, unless in marly, forest-lands. The Congo-pea (Cajanus indicus), one of the best of pulse-bushes, has yielded in rich alluvial soil the almost incredible quantity of two tons of pea from an acre; a further recommendation of this shrub is its adaptability also to dry ground. Annual Gram-plants ought to become redisseminated spontaneously in many, especially marly localities; so also the Ground-pea (so valuable for its oily seeds), the Bersin-clover, and others. Conflagrations of the bush can be effectually arrested, if cultural spots are lined by Opuntias (on which again Cochineal may be reared), or by Agaves from which the Pita-fibre, and by Phormium from which the New Zealand flax is obtained, these plants neither being inflammable nor likely to perish altogether when they are scorched. White Mulberrytrees admit of being trimmed into hedges, and would thus conveniently afford food for silkworms on any farm, wherever needed or desired. The Adeira Arrowroot of Peru (Canna edulis) would grow vigorously down to the most southern portions of the colony, in almost any soil of trifling fertility.

Wherever waste sands are likely to encroach the dissemination of native maritime bushes can be powerfully aided by the incomparable Sandstay-shrub (Leptospermum laevigatum) of South-East Australia, and by establishing the famous Moram Bent-grass (Psamma arenaria), and the tall Sea Lyme-grass .(Elymus arenarius), both of which tall widely.creeping grasses (through the instrumentality of the writer) have found a permanent home already on the drift-sands of the Victorian shores. Cynodon and Stenotaphrum are here also of immense value for fixing the moving sand-waves. In California large kinds of Lupins are preferentially chosen for the same purpose, while the annual yellow Lupin (Lupinus luteus) is the best for raising the first fodder-crop or green manure on sand-lands, where the absence of lime forbids the culture of Sainfoin and many other fodder-herbs. One of the best native tanners' Acacias of West Australia, A. saligna, with the eastern A. pycnantha, will arise, if properly sown in the autumn, from even seacoast- and desert-land. I should like to see the annual Peruvian Sunflower naturalised on any forlorn spot for the sake of its oily fodder-seeds.

Many waters, whether stagnant or fluent, whether in or out of the forests, can contribute their share to the economic resources of the colony by being made the vehicles of particular alimentary plants. Let us only be reminded of the Trapa Water-nuts, the North American Zizania grasses (Z. aquatica and Z. miliacea), the Kausum, another Zizania (Z. latifolia) from China, which yields a culinary vegetable, and the Solah-pith plant (Eschynomene aspera). How far south the two Nelumbos of Asia and North. America will endure the clime remains yet to be ascertained; but they have been traced to the 44th degree in the northern hemisphere. Nelumbo nucifera is with real Rice indigenous in the waters of Arnhem's Jand, and both are probably natives also of the West Australian northern territory. Further information on prominent utilitarian regetation is offered it. the "Select Plants," in which work all industrial species are also classed for easy reference according to the locality inhabited by them.

C. The tropical littoral tracts of West Australia provide ample areas for most plants of the equinoctial zones, although the humid coast-valleys do not perhaps extend very far inland, and soon merge into the drier open regions of the wide interior. The geologic formation of the northern regions of Western Australia remain almost unknown, indeed that portion of the territory 
to a great extent geographically unexplored; hence the limits of the trap-formation and of the rich alluvial deposits, which would yield the most fertile fields in sheltered positions for tropical products, continue unascertained. The natural boundaries of culture plants in intra-tropical and sub-tropical regions is also not always strictly defined by degrees of latitude, indeed their geographic circumscriptions depend often on a multitude of circumstances, climatic, topographical, and geological. Thus, cotton-culture advances elsewhere from the tropics to fully $36^{\circ} \mathrm{S}$. latitude; Bananas ripen under shelter of limestone cliffs as far south as Swan River at $32^{\circ} \mathrm{S}$.; Mangos perfect their fruit beyond the tropics in the Himalayas, even up to 3500 feet; Coffee culture continues prolific at temperate elevations of 4500 feet in Ceylon, so long as the large annual rain precipitation, needful for the luxuriant growth of this highly useful plant, is obtained; the Breadfruit-tree stretches in the Sandwich Islands almost beyond the tropics, while its congener, the Jack-tree, advances on mountains in India to elevations of fully 4000 feet, and has borne the clime of Sydney, where also, in $34^{\circ} \mathrm{S}$., the Durian-tree became acclimatised. The culture of Sugar-cane, which extends to the countries bordering the Mediterranean Sea, is still profitable at $32^{\circ} \mathrm{N}$. in America, and succeeds in the northern parts of New South Wales. The Persea- or Alligator-pear has for a long period been naturalised as far north as the Azores, while the Cassava or Tapioca-plant advances southward to Uruguay; Taro is hardy even somerwhat further south; some of the best Dioscoreayams can be cultivated successfully in the northern portion of New Zealand; the Palmyra-palm yields its enormous masses of sugar even in Persia, a country completely extra-tropical ; the best and largest of all Bananas, the Peesangs (Musa simiarum), which has never been introduced into Australia, is also likely to bear the climate very far south.

This may suffice to show that the southern limits of tropical culture, whether of foresttrees or any other plants in Western Australia will very much fluctuate under different meridians and parallels, and according to the particular endurance of any species. What timbertrees should be added to the Eucalypts and the ferw other large trees with superior wood, indigenous to North-West Australia, must become an object of experiment in many places, as colonisation proceeds northward and inland. It is, however, quite likely that some of the Eucalypts peculiar to that portion of our continent will prove most valuable for increasing the wood supply by cultural means, particularly in the inland-districts. Indian Red Cedar, Teak, and Sal, the best of Ebony-trees, various Guttapercha-trees, West Indian Mahogany and Cedar (Cedrela odorata), the Copal-trees of different parts of the globe, the South Asiatic Gamboge-trees, the best Central American Caoutchouc-trees of the genera Hevea and Castilloa, and a multitude of other arboreous species yielding dyes, and particularly furniture woods in various tropical countries both of the eastern and the western hemisphere, are more particularly fit for plantations in the humid littoral northern regions. A whole host of Nageia-pines from South Asia, Africa, and tropical America would furnish pine-timber in localities where the firs recommended for the southern districts would no longer prosper; to these could be added several splendid Kauri-pines from Polynesia and India, calculated to replace in warmer zones the coniferæ of the north.

As forest management is nowhere restricted. merely to the conservation, multiplication, and best utilisation of timber-trees, though that is its primary object, it will not be out of place here to allude to the Indian Mangostan-tree with its luscious fruit, the Central American Cacao-tree, which produces the chocolate, the Coconut-palm, which an enlightened missionary has recently recommended for permanent beacons on emersed Coral-reefs. If it were an object, the whole of the Palms of the globe, exceeding one thousand species, could by cultural processes be established in different localities of Western Australia; but on this occasion I will only recommend the early introduction into tropical latitudes of the Sago-palms, the Oil-palm of Guinea, the majestic Wax-palm which attains in the Andes a height of 180 feet, the Carnauba or Wax-palm of Brazil, the starch-yielding Oreodoxa of the Antilles, the Ivory-palms of Peru, the wonderful Seychelles-palm before that glorious plant becomes 
extinct, the Peach-palm of the Amazon River, and the Hyphaene-palm of East Africa ; whereas, from among the hardier species may be singled out for the extra-tropic latitudes the Chilian Treacle- or Coquito-palm, the sugar-yielding Caryota-palm of India, the tall Toddy-palm or Palmyra extending westward to Persia, all magnificent objects for scenic effects, all of highly utilitarian importance also, all readily raised from seeds, if such are obtained fresh. Bamboos, so important for their multifarious application, and so easily increased and distributed when once introduced, could in their most majestic forms embellish all the Western Australian landscapes except the most scorched desert-country. In Tenasserim, Bamboos rise to heights of 150 feet with a diameter of fully one foot of their mast-like canes; the great West Indian Arthrostylidiums are nearly as high and columnar. The mighty Dendrocalamus of Pulo-Geum is also of enormous size, while in Java some Gigantochloas grow to a height of 120 feet, with a girth of 22 inches. The Bamboos now already known amount to about 170 species, many of stupendous height and marvellous rapidity of growth, and of these a considerable number can be transferred even to the southernmost limits of Western Australia, as some of the Chusquea Bamboos reach high elevations on the Andes, while several Himalayan Arundinarias advance to nearly the snow-line. It would need a volume to enumerate whatever foreign countries could contribute to the wealth of West Australia, which, so far as cultural capabilities are concerned, excludes from its zones in reality only the Arctic and Alpine vegetable organisms, and which can afford apt space and shelter in select spots also to every Palm in existence. But this Report would become extended to an undue length, and would deviate from its primary intentions, were I to dwell still further on the almost endless forms of plants, particularly from intra-tropical parallels, which the industry and intelligence of the colonists of a great and rising country are sure in the course of time to render their own for the augmented enjoyment and prosperity of coming generations.

\section{IV.-INITIATORY MEASURES SUGGESTED FOR ESTABLISHING FOREST}

\section{ADMINISTRATION IN WEST AUSTRALIA.}

\section{A.-Local Forest Boards.}

To effect a vigilant surveillance over such wide forest-tracts as those of West Australia, it is suggested that the central-office administration should in the first instance be aided by local Forest Boards, each consisting of a few members chosen for the sake of their experience in wood industries, or for their predilection for cultural pursuits. Such Boards would readily meet once a month, inspect periodically the local forests under their control, would frame such regulations for aiding the centraloffice as would be best adiuted for preserving, increasing, and utilising the woods of their own districts, would lease out forest-lands, sell timber in circumscribed areas, would issue licences to woodmen, direct measures for new cultures, guard against waste, choose means to utilise the collatera] products of their forests, and foster or create industries for obtaining potash, charcoal, tar, vinegar, alcohol, dyes, tanners' material, and other products or educts from their local woods. At the commencement it might suffice to station merely one State officer in each district to be the practical functionary of each local Board, to whose directions he should be amenable, while measures of general importance would all remain subject to final Ministerial approval and surveillance. In the first instance, an industrious man, merely of horticultural experience, circumspect intelligence, and of modest aspirations, would locally suffice for giving effect to the earliest resolutions of each Board. 


\section{B.-Revenue from Forest Areas.}

The local Boards should be empowered to raise revenues from the areas entrusted to their. care, in order that their decisions on any subject of protection or improvement of the forests should not remain inert for absolute want of monetary means. Wise statesmanship does not expect to raise extensive incomes from forest-lands without re-voting at least a portion of the funds so obtained for renovating, or for enriching to some extent, the very forests which yielded the revenue, not to speak of the occasional or frequent necessity of enlarging or even creating forests, where timber may be scanty or altogether wanting. These two cardinal measures-namely, the appointment of Forest Boards and their endowment with a portion of the forest revenue-were recommended by me long ago as the first steps necessary towards establishing an initiatory forest administration in any new colony, where forestry according to modern European organisation could not possibly be initiated at once, while the population remained scanty, and the income of the colony very limited, in comparison to that of densely populated older States. The adoption of these two primary measures I advocated for many years for all parts of Australia, and set them fully forth in a lecture on "Forest Culture in Relation to Industrial Pursuits," copies of which in 1871 were widely circulated, and reproduced also in America. In this lecture I explained also at length the importance of maintaining forests on climatic and hygienic considerations, and for the sake of controlling and regulating to a large extent the water-supply and its distribution over any country. This lecture might deserve, perhaps, re-issue in West Australia.

\section{C.-Survey and Reservation of Forest Areas.}

It is important that in any country, even where private enterprise fosters forest-culture, extensive areas of woodland should not be encroached upon, but be retained by the State, to place the final alienation of all forests from Government beyond possibility. Such reserved and carefully surveyed areas would best remain unbroken, and therefore private settlement should be excluded from them. Wherever possible natural boundaries, especially those afforded by watercourses, should be secured. This foresight ought to leave to the State the control over many of the principal sources of rivers, and would enable the forest department to seize at any time on any such wooded Crown-land needed for cultures-whether of trees or any other plants-as could not exist or would not prosper outside of forest-regions. Such reserved woodland might, under due restrictions, be leased out by Forest Boards to pastoral tenants, to obtain a revenue without injury to forest-interests, and leaving it optional for the State to resume full possession of the woods whenever cultural or technical operations in the area became expedient there.

\section{D.-Disposal of Timber, Fuel, and other Forest Products.}

The necessity of surveillance over the existing timber-resources of the State in order to prevent waste, and to encourage, regulate, and protect the natural upgrowth of young trees, cannot be too rigorously insisted on ; furthermore, it must be the object of an enlightened forest administration to frame and enforce rules, according to which timber of the best quality should be cut at that season when the circulation of the sap is least active, in order that, for the credit of the timber-resources of the colony, wood only of the best kind obtainable may come into the trade. The renovation of superior timber in the Eucalyptus forests can also greatly be aided by timely removing saplings, where theyhave arisen too copiously for the proper final development of well-formed trees, and by filling up empty spaces, through sowing or planting operations, with the view of deriving the greatest possible return from the whole forest area. Arrangements for the earliest renewai of the forest, wherever: denuded by the removal of timber, devolves also on a regularly-established forest administration; 
moreover, in West Australia the very important question must arise whether the removed trees are to be replaced by native species of the same kind, or whether to some extent trees of foreign countries should be sown or planted. In the latter case, it involves much consideration and inquiry to choose for each climatic region, and for each geologic formation, those particular species best adapted for the respective localities; and in this respect many indications, given in my work on "Select Plants," will to some extent prove available for guidance. As elsewhere, so also in West Australia, one of the leading considerations for forestry will be to decide on the systems of removal of timber, whether by the total sale of all the wood on defined square miles, or by numbers of trees within surveyed areas, whether by restricted licences or by any other well-meditated mode. In all such measures the local Forest Boards could afford the best advice to the central administration.

\section{E.-Importation of Seeds and Plants.}

The mode of adding to the natural constituents of a forest from abroad may be twofold; either by interchanges or by direct purchases of the plants or seeds desirable for any forest locality. Importations by purchase of seeds tend on the whole to the speediest and most extensive enrichment of forests, although the treasures of woodlands can be largely augmented also by sending abroad seeds of native plants, to secure in reciprocity those eligible in other countries, whereby, moreover, the resources of the colony become thus far widely and instructively known. The least expensive and the simplest mode of obtaining seeds in quantity, from which vast additions to forests can be realised far more cheaply and speedily than from the introduction of living plants, is always by simple mercantile trade. Orders for seeds might, however, be brought under the control of consular officers, directors of scientific gardens or other competent authorities, to secure by their aid the selection of the right kinds and of fresh and well-matured seeds, and also a careful system of packing and despatch. West Australia is singularly fortunate in being able to initiate an extensively ramified system of interchanges in seeds, as, indeed, very few countries in either hemisphere can vie with the western colony of Australia in the numeric richness and the elegance of its exclusively endemic forms of plants. The Geographic Index appended to my work on "Select Plants" would afford aid in ordering from any part of the globe seeds of such plants as would prove hardy in SouthWest Australia for either forest-culture or agronomic purposes.

\section{F.-Establishment of Local Nurseries.}

Both for immediate extensive supplies of trees of recognised value and for plants intended merely for experimental tests, local nurseries in the forests themselves need to be established, the transfer of living plants on a large scale from one locality to another being beset with difficulties, subject to great losses, and involving proportionately large expense. For forest purposes, it is not sufficient to plant a limited number of trees; if practical results are to be attained trees must be raised by humdreds of thousands. Rarer kinds, or such as are apt to succumb in their earliest stage of growth, are, as a rule (subject to some exceptions), best planted out at defined distances as seedlings from nursery-beds, whereas the seeds of commoner and hardier kinds of trees can be scattered best (after some cheap preparation of the soil) at once in suitable spots of the forest, particularly at the end of the hot season. Forest-nurseries serve simultaneously for raising many kinds of plants besides forest-trees, but fitted only for a forest clime, to obtain from them a remunerative additional yield of the woodlands. From forest-nurseries plants can be distributed to a limited extent for tests in various localities with different soil and clime. When a local trade in any important plant has sprung up, the opportunity often arises for forest administrators to secure at a nominal price the surplus of plants or seeds, after private estates are supplied, for the State forests. 


\section{G. - Test Plantations.}

Irrespective of the local nurseries under the supervision of each Forest Board (to the formation of which was alluded already), it would be advisable to create three general experimental plantations, one in each of the principal climatic regions of the West Australian colonial territory. At the commencement it would suffice to station, as an operator on each of these three plantations, only one person, who should combine zeal and circumspectness with plain horticultural ability. A series of tests could then be initiated and annually recorded, to guide settlers in the selection of particular plants for their gardens, farms, pastures, or forests. These experiments would indicate also to which trees preference should be given in each of the main climatic regions before the more expensive and toilsome process of rearing foreign species in masses comes into operation. Thus, also, an endless array of fodder-herbs and grasses could be tested, which naturally are of such very scanty occurrence in most of the districts of Western Australia, while of long introduced cultureplants, such as, for instance, the Tobacco, the distinct qualities arising in different latitudes and on various soils could readily be made known. Moreover, the Tobacco-plant delights in rich forestsoil, particularly where limestone prevails, on account of the potash combinations which abound in woodland soil, and also as in the clearings of forests the atmospheric humidity prevails which is needful for the finest kinds of 'Tobacco. At such centres of cultural experiments, sustainable at a very modest expenditure, means for irrigation should be within reach for increasing the scope of the experimental inquiries. On providing for the two cardinal requirements of West Australia will to a large extent depend the increased future prosperity of the colony-namely, on the augmentation of the water supply - either by mere storage, or by the more costly but in time largely remunerative process of Artesian borings-and on the copious dispersion of perennial grasses and fotder-herbs best adapted for each zone, and which by their gradual spread will add unceasingly to the country's wealth.

Though the intra-tropic portion of West Australia is only under incipient settlement, it would be a wise measure to commence early test-cultivation of tropical plants also at Nichol Bay. The small outlay involved will be a thousandfold regained in periods not distant. Test-gardens further north could be formed as gradually colonisation proceeds in that direction. Almost a countless number of plants of industrial and pastoral importance could be reared in the tropical latitudes of West Australia, many or most of which would not thrive further south. Again, it will be found that the coast-country towards Arnhem's Land belongs to the zone of the Spice-plants and general equinoctial vegetation, while the drier inland regions, in which the temperature sinks very low during the nights of the cool season, will prove more adapted to sub-tropic plants. The limits of these zones of vegetation can best be ascertained by practical tests, such as could be extended by distributions of plants from a few original plantations on the coast.

\section{H.-The Creation of a Museum of Vegetable Products.}

A powerful and very demonstrative auxiliary for diffusing knowledge on forest-trees, and indeed on any other utilitarian plants, is afforded by an economic and technologic Museum. Such may be made an adjunct to a general Museum, or be maintained as a separate establishment, according to local circumstances. In either case such an institution need not be burdensome by claiming costly endowments; but, whenever possible, it ought to be connected with a real Botanic Garden, in which under scientific direction the various plants important to trade, facteries, dispensaries, workshops, and households are cultivated, and geographically, systematically, and technologically grouped, so as to be readily accessible for information, with the least sacrifice of time. The timber of various parts of the globe, together with other forest-products, would necessarily be included among the subjects prominently displayed in such a Museum. Much can be accomplished by inexpensive methods in this direction under judicious and experienced management. 
In concluding this general Report on the forest capabilities of Western Australia, I am conscious - that many important questions bearing on the subject under consideration have remained unanswered, while other points have been insufficiently discussed. But within the limits of one preliminary document the multifarious aspects of the forest-interests of a vast country, with territorial possessions both in the temperate and the hot zone, could not be exhaustively scrutinised, even if more extensive opportunities for research had arisen to the writer. It will, however, be to him a pleasing task to aid further in the development of the great resources of West Australia, as he may fairly claim to have done to some small extent during the last quarter of a century, and he can foresee that before another generation has passed away, the whole of the immense extent of that great country will be densely occupied by settlements, and will under its winterless sky afford happy abodes and scope for innumerable industries to many millions of prosperous inhabitants. 


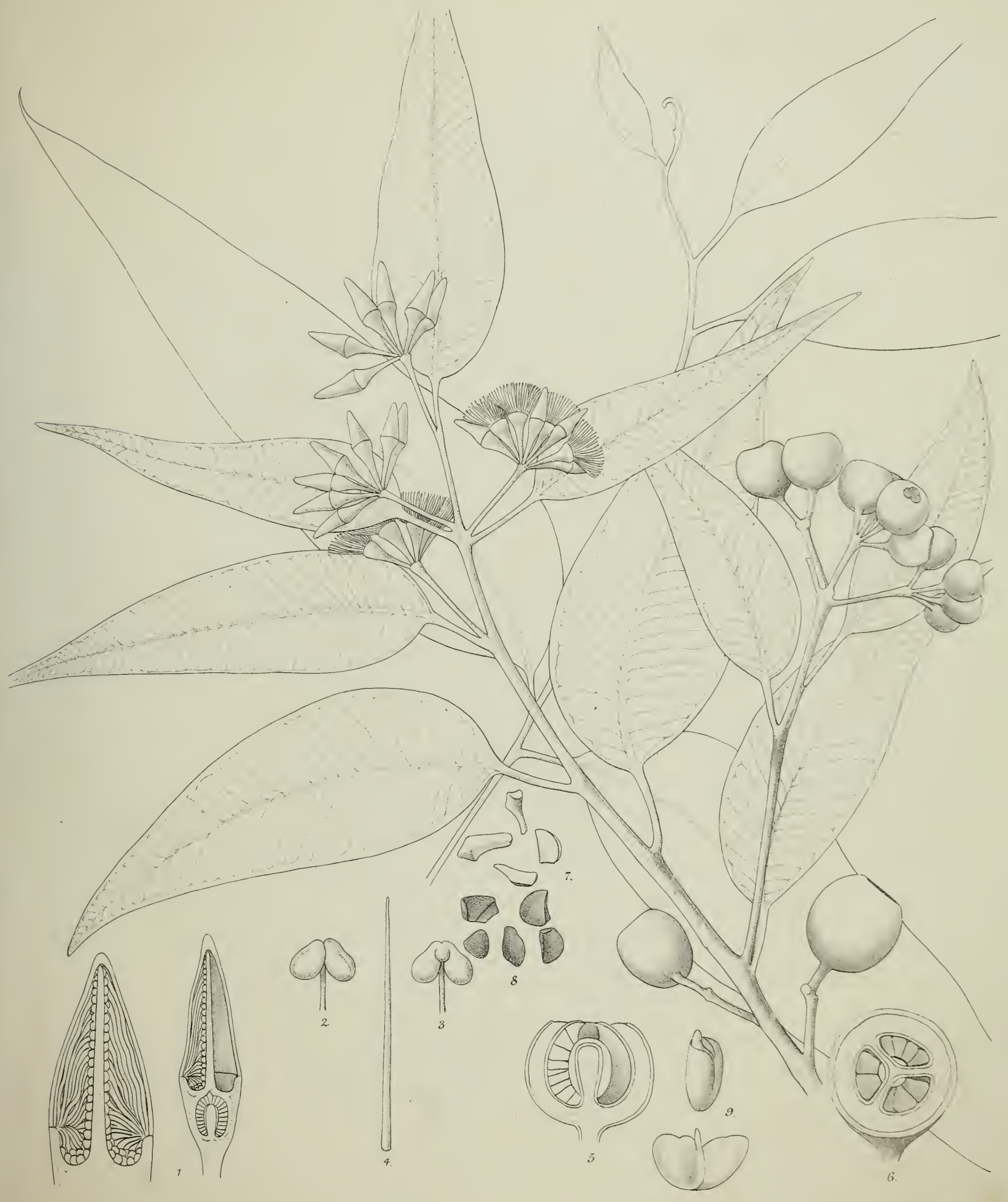

R Austen del. JN.FitehiLith

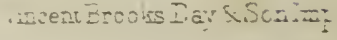





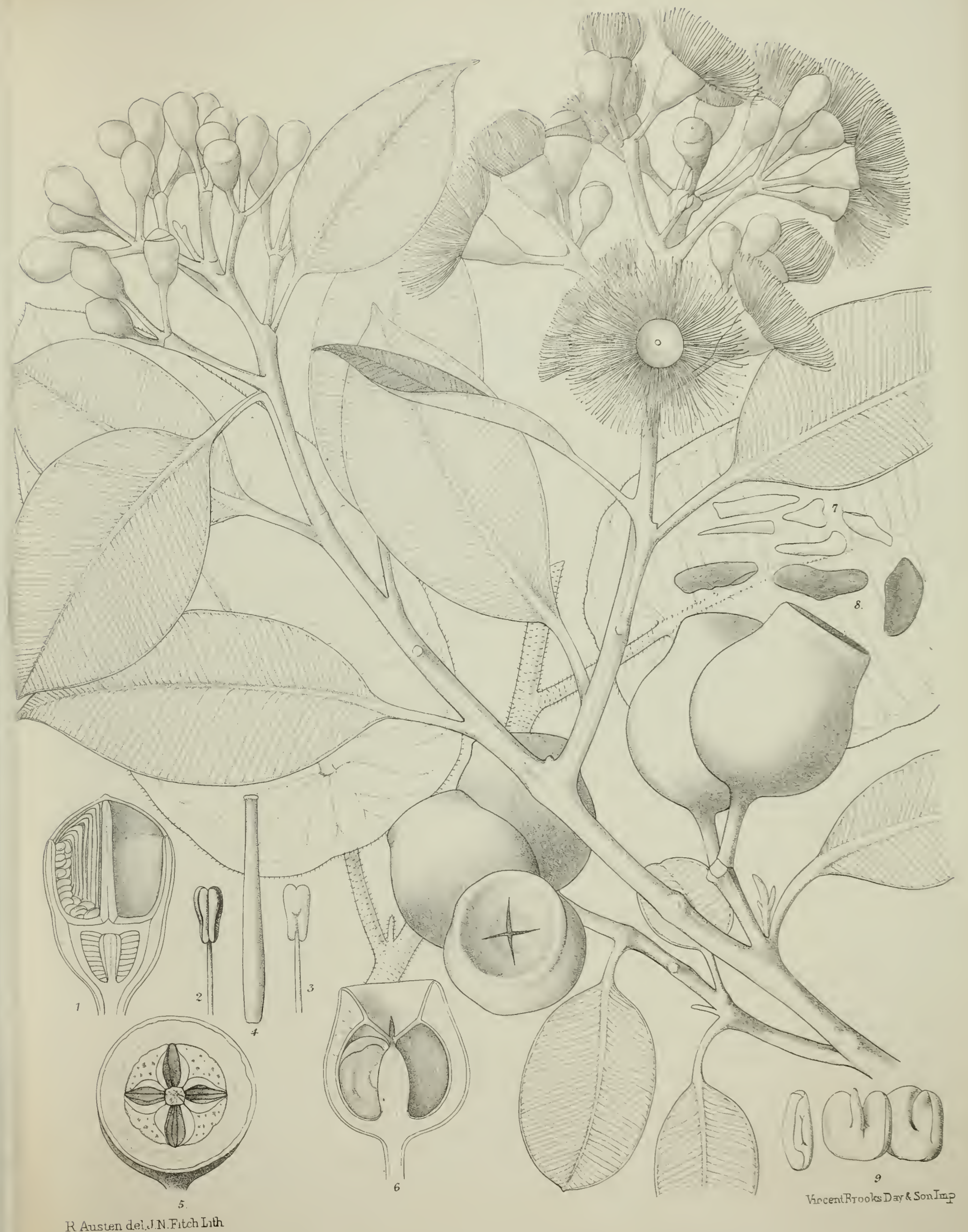

FUCALYPTUS CALOPHYLLA 



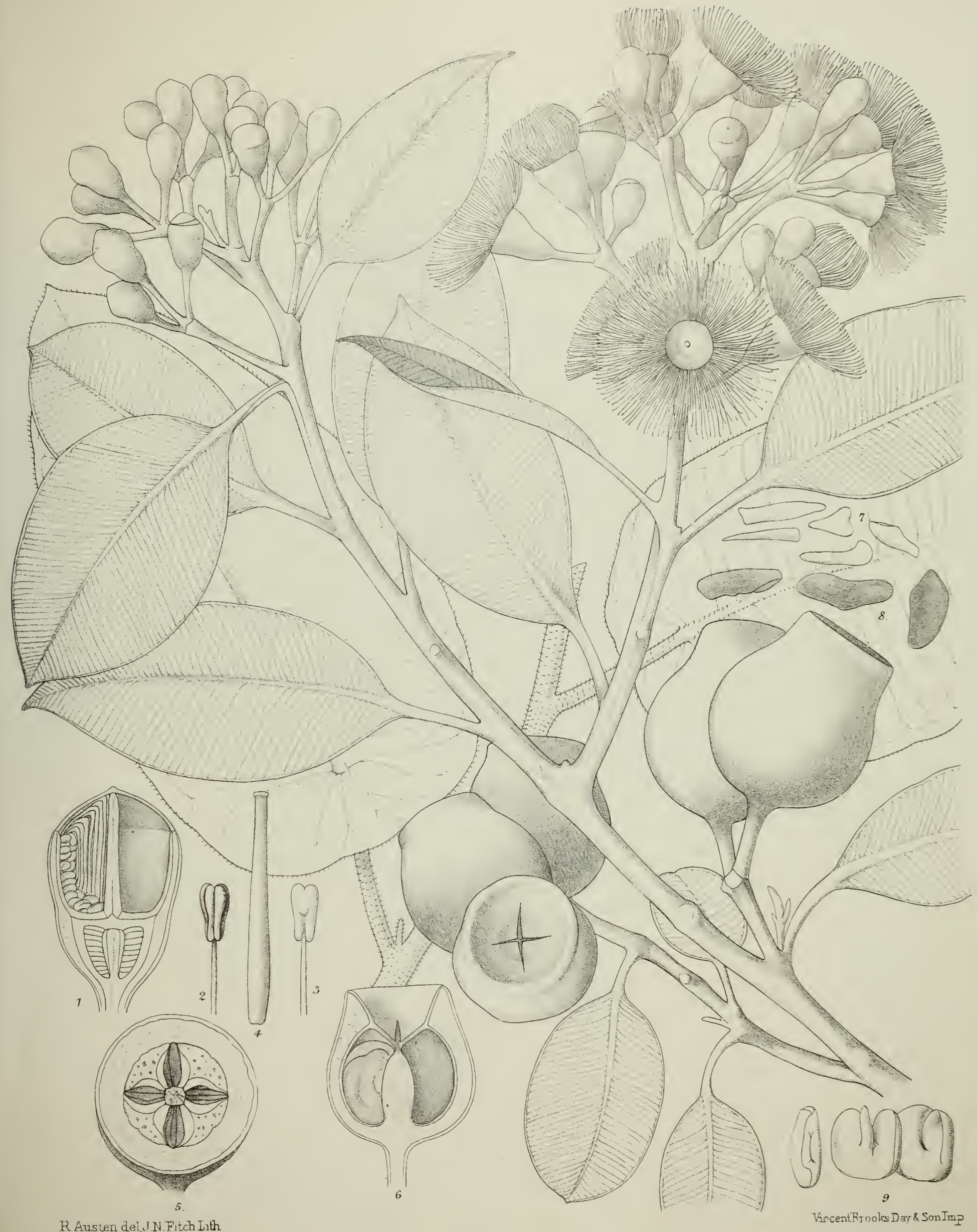

EUCALYPTUS CALOPHYLLA. 



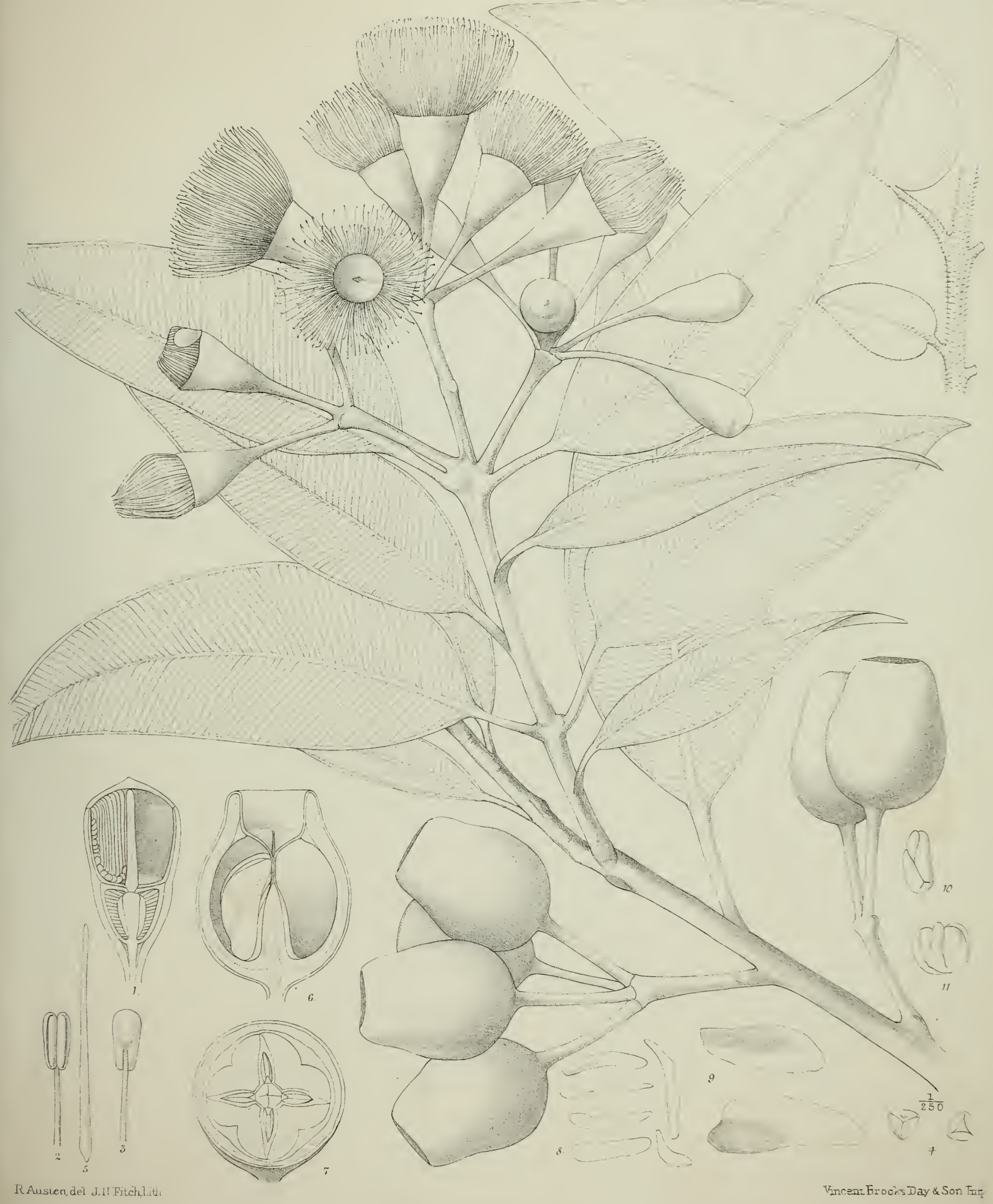





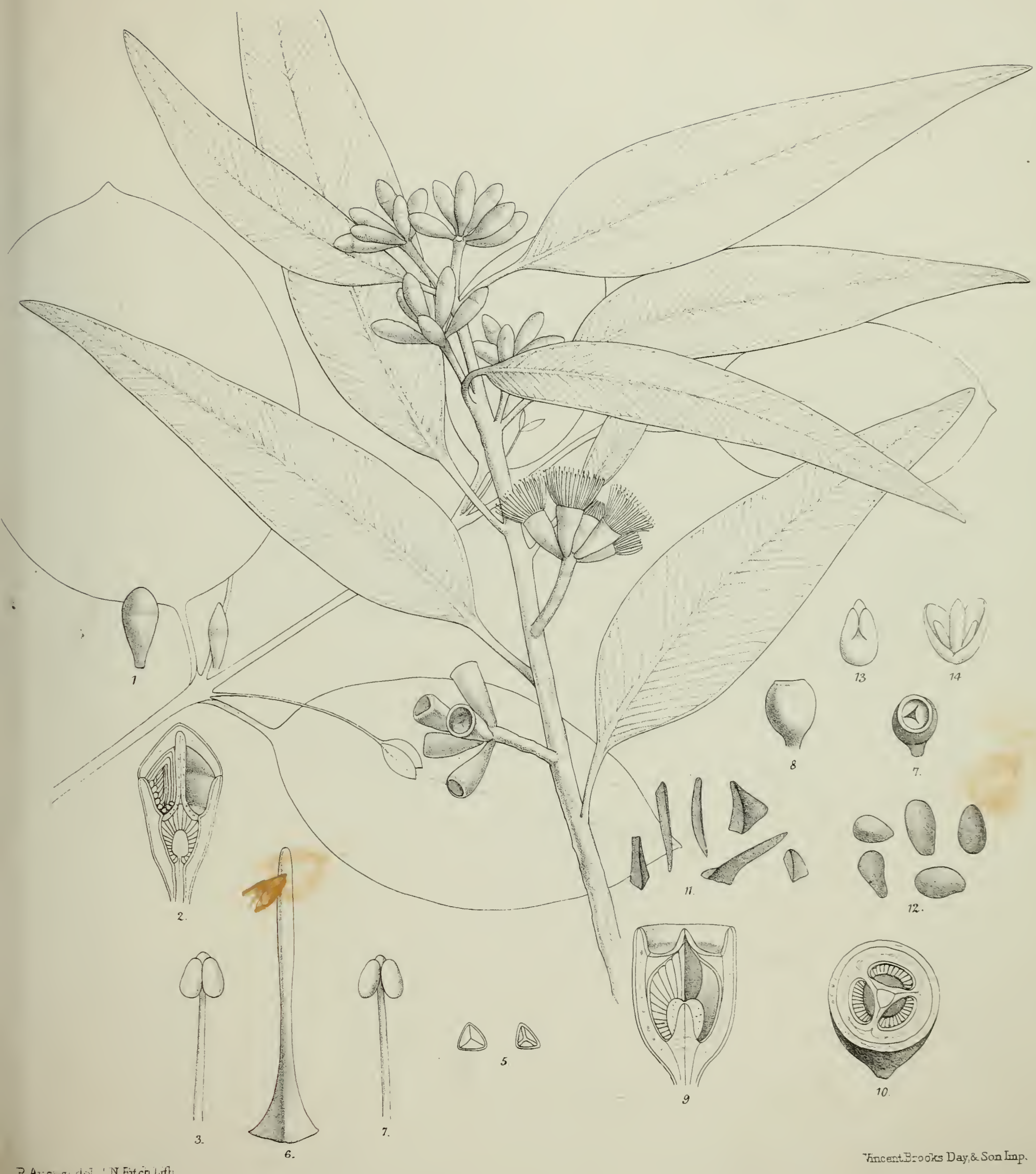

EUCALYPTUS DIVERSICOLOR 



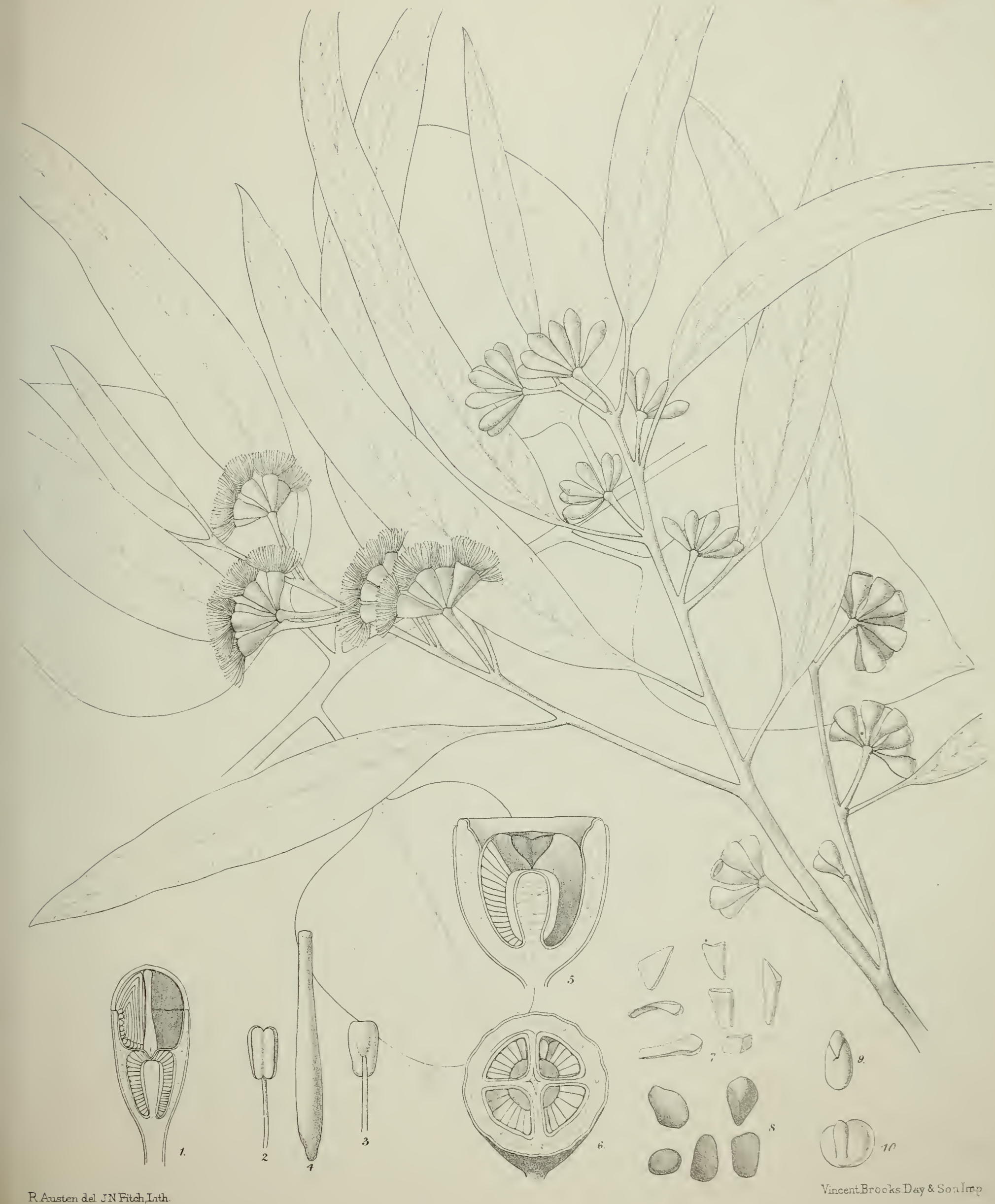

EUCALYPTUS IOXOPHLEPA 



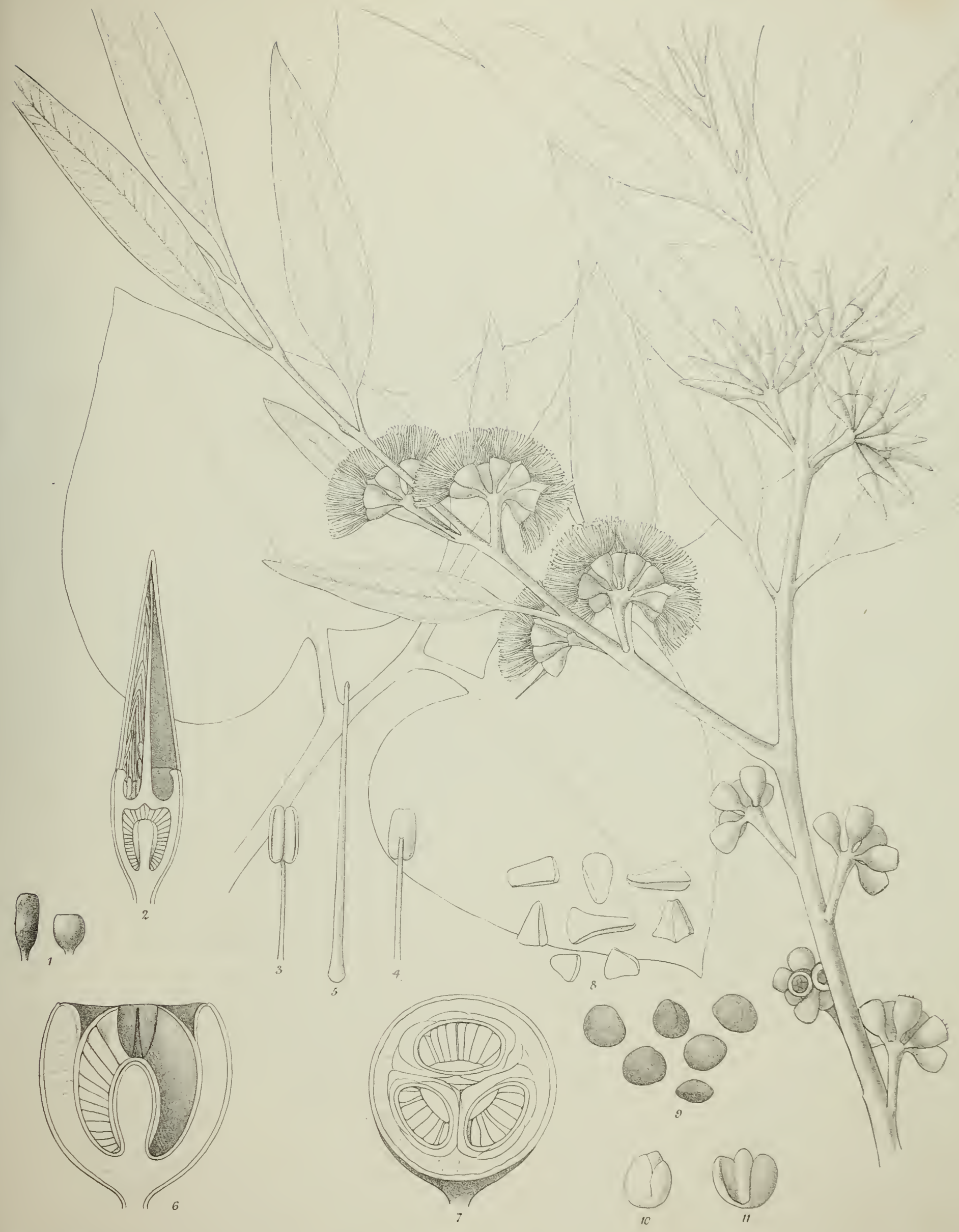

RAusten del, Jis Fitch, Luth 



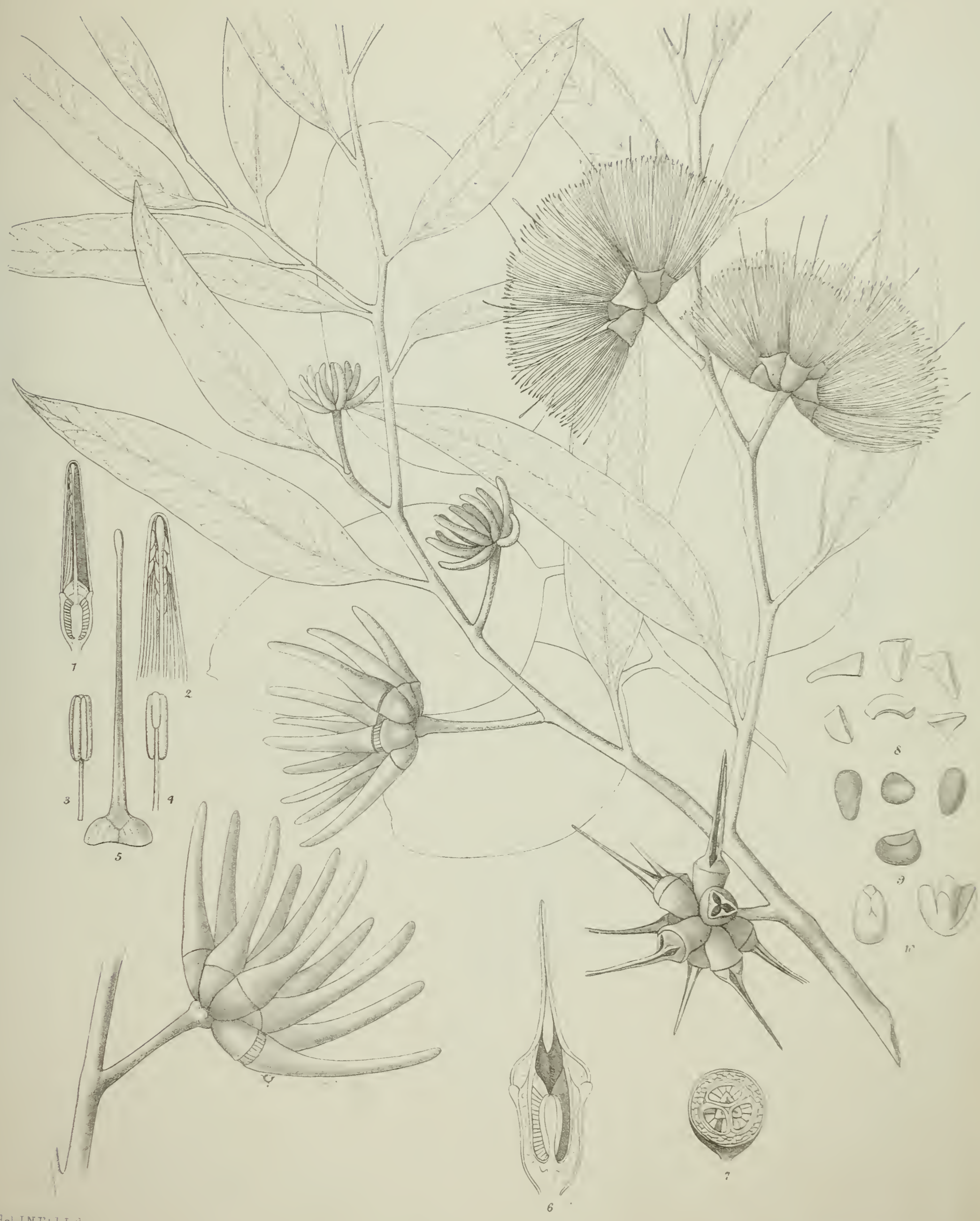

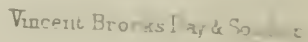





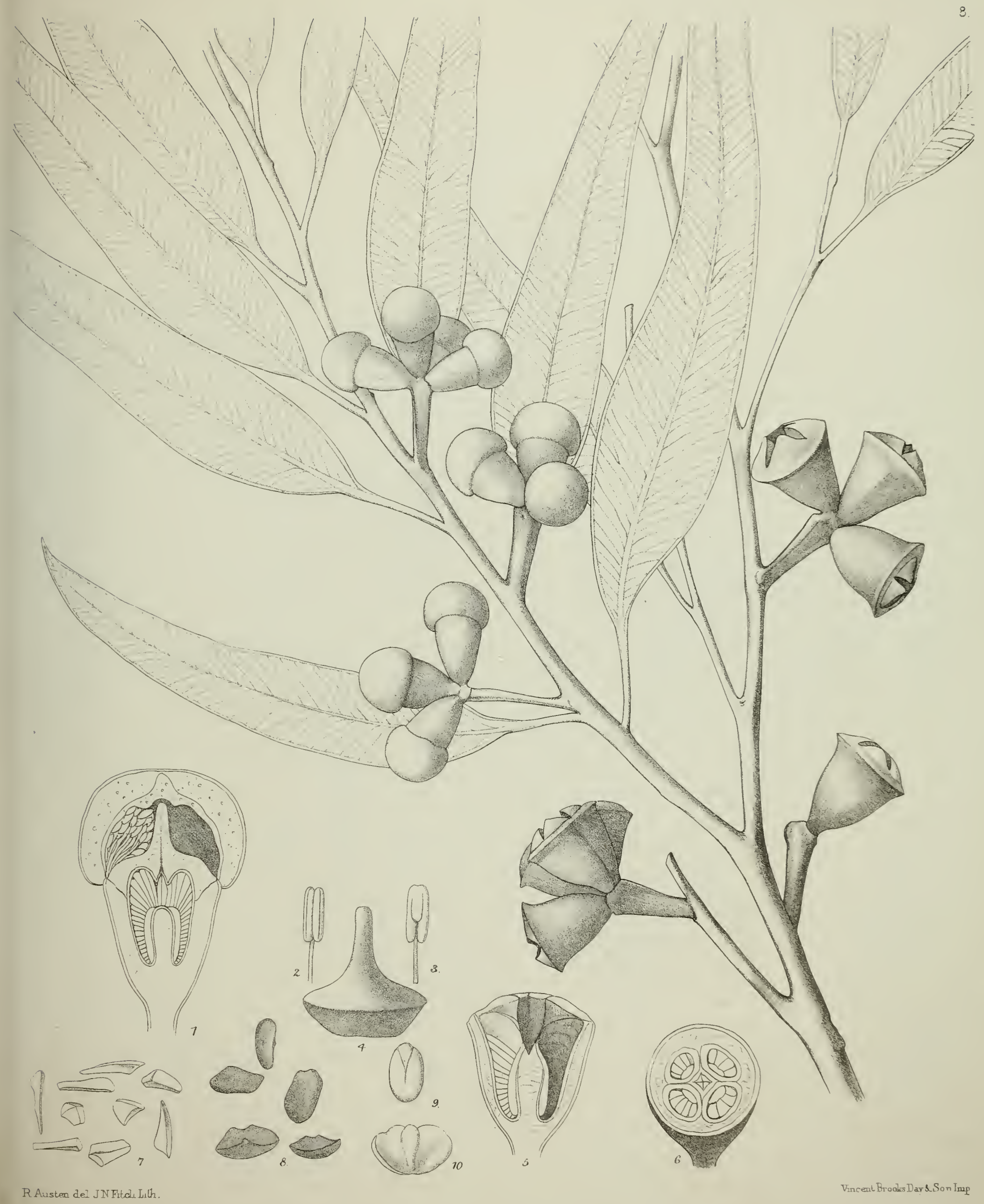





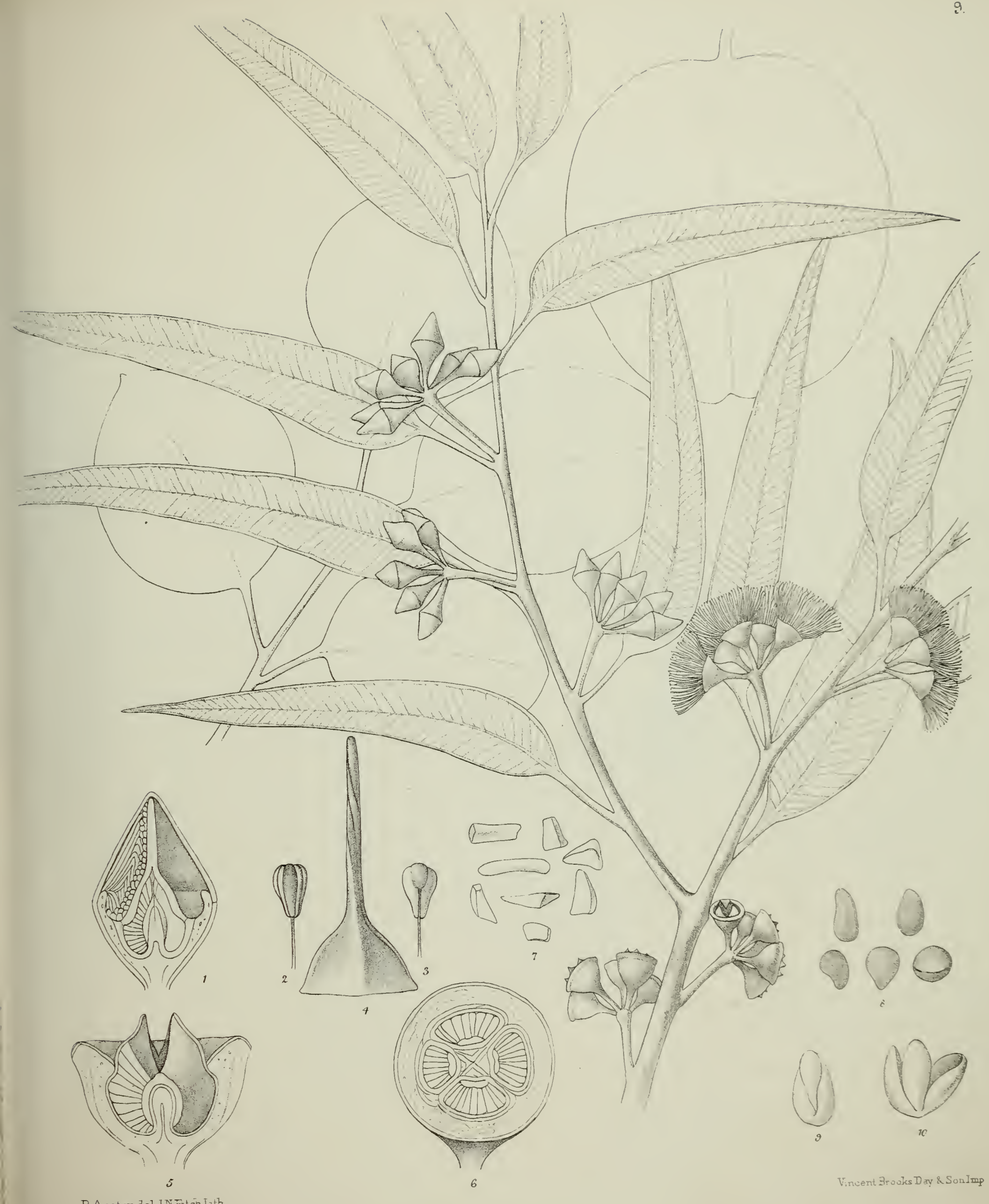

EUCALYPTUS RUDL'- 



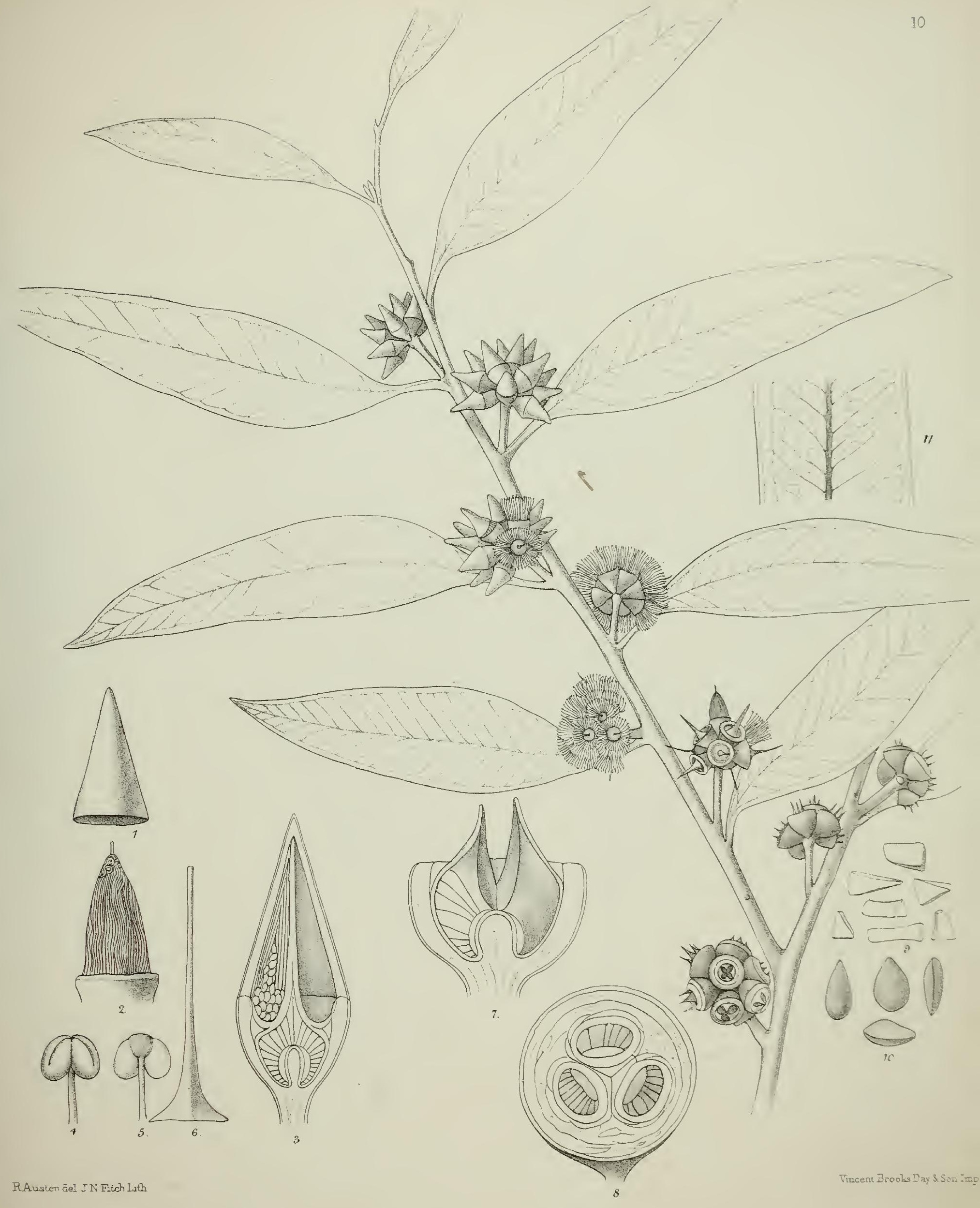

EUCALYPTUS DECIPIENS 



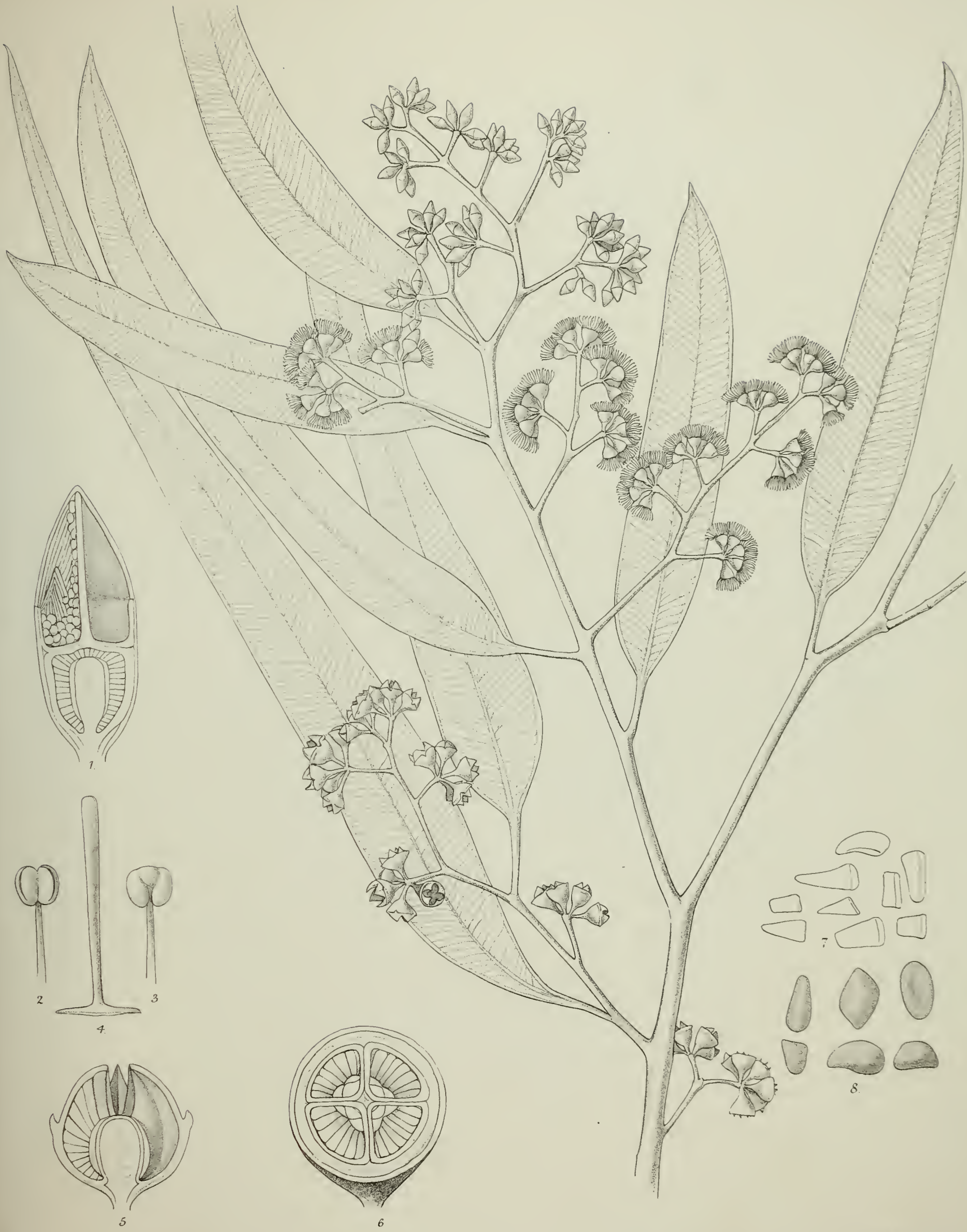

Vincent Brooks Day 3 Son Imp

RAusten del,J.N FitchInthe 



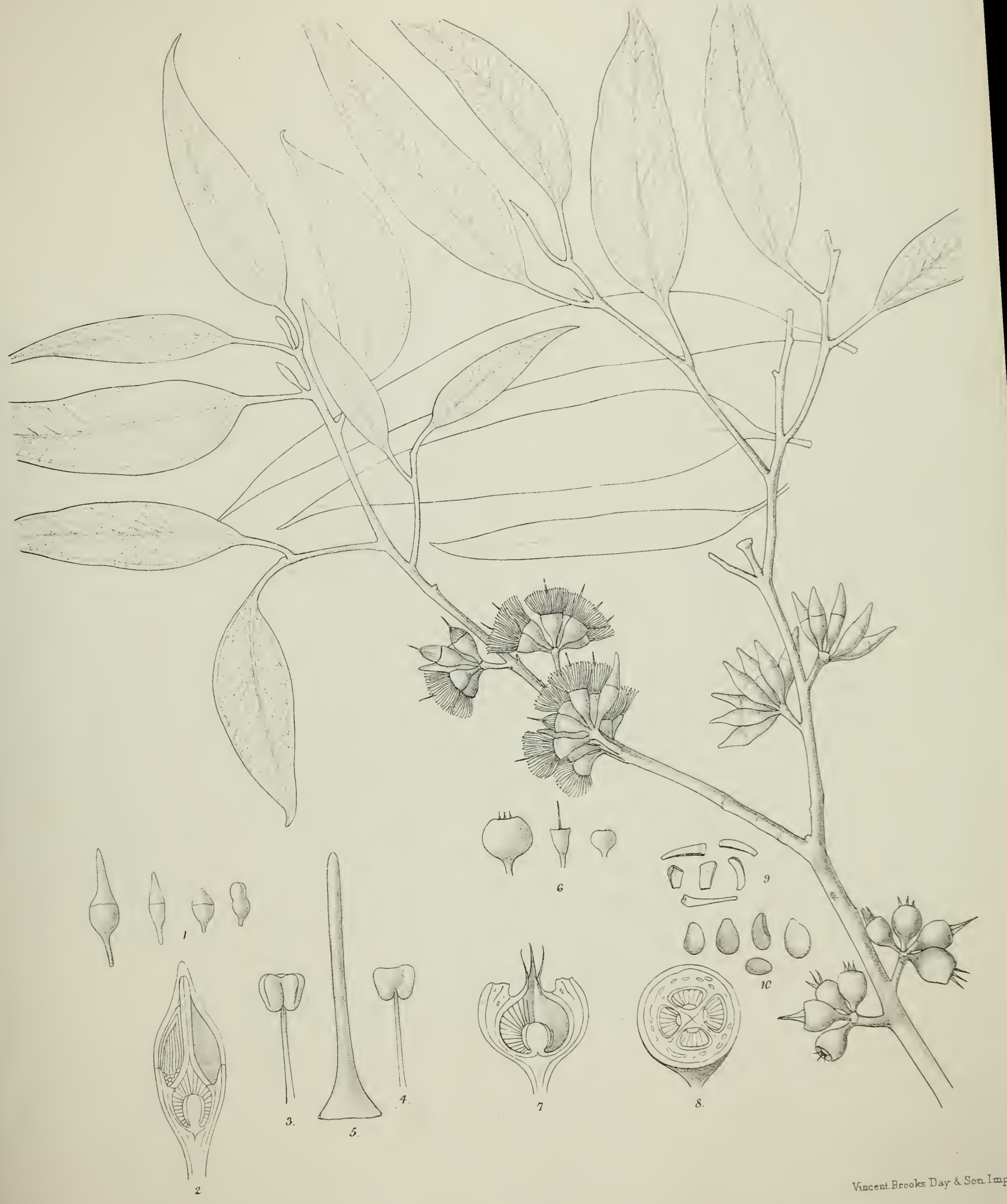

R. Austen del J.N Fitah Lith

EUCALYPTUS OLEOSA 



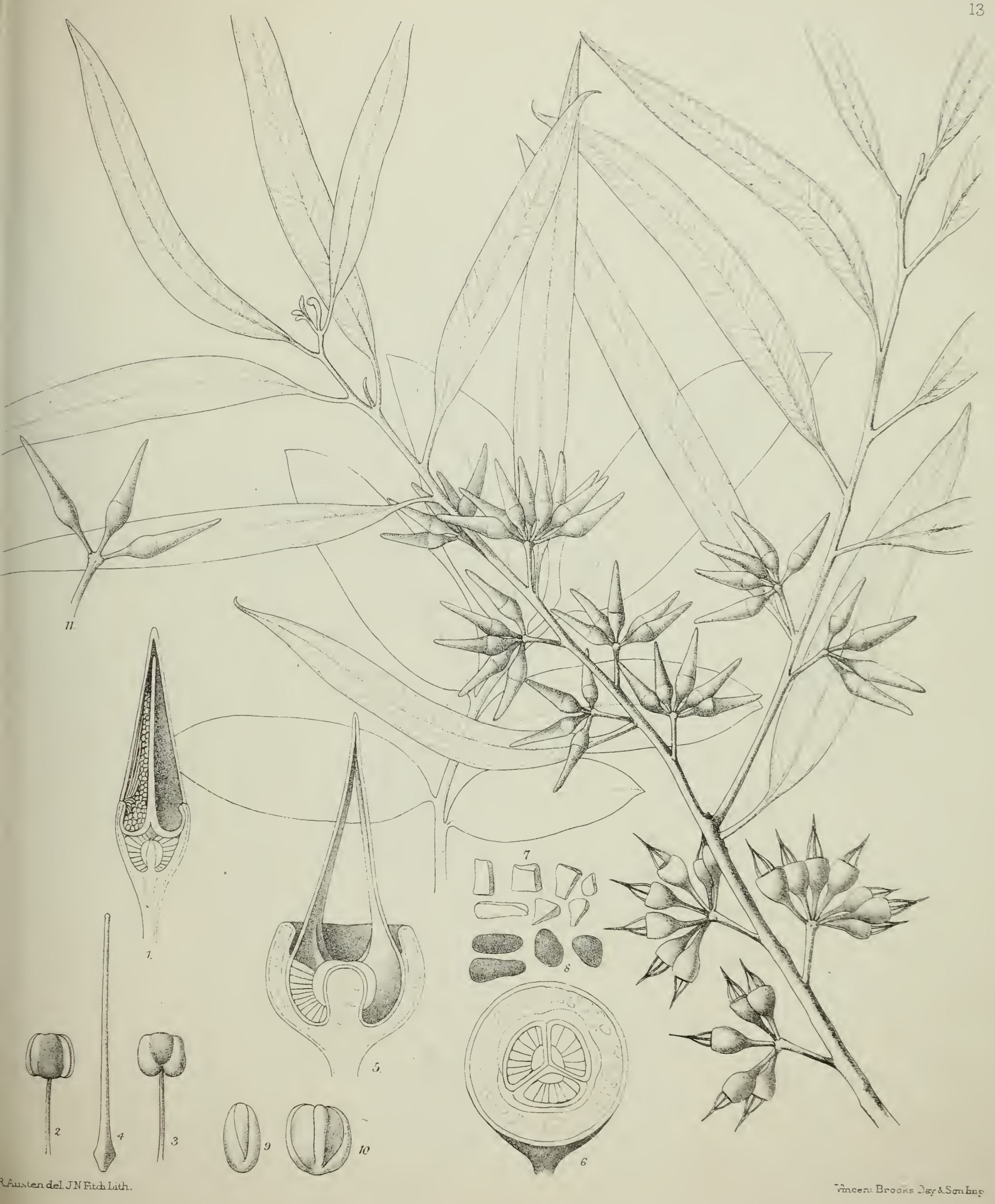

EUCALYPTUS LONGICORNIS. 




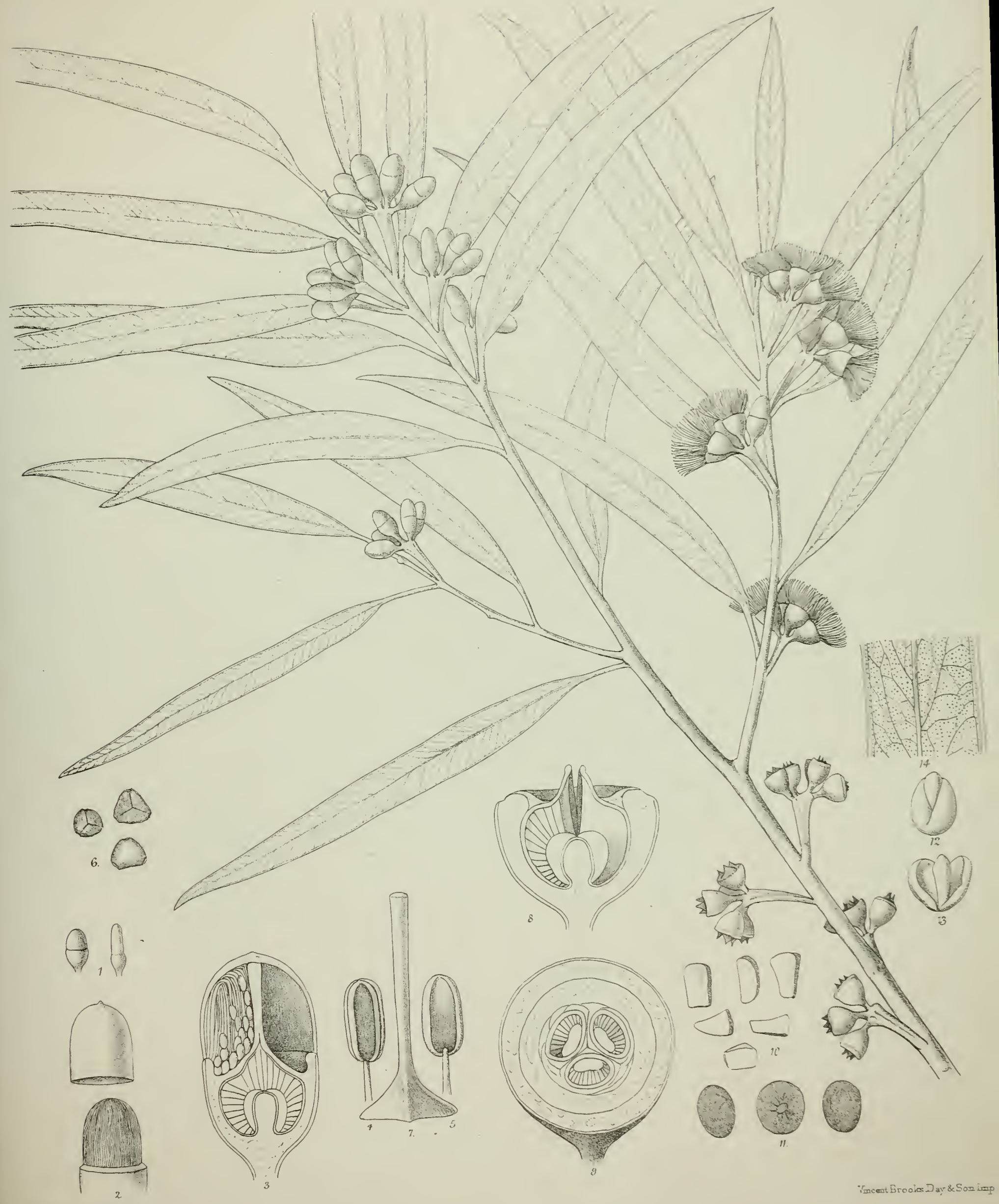





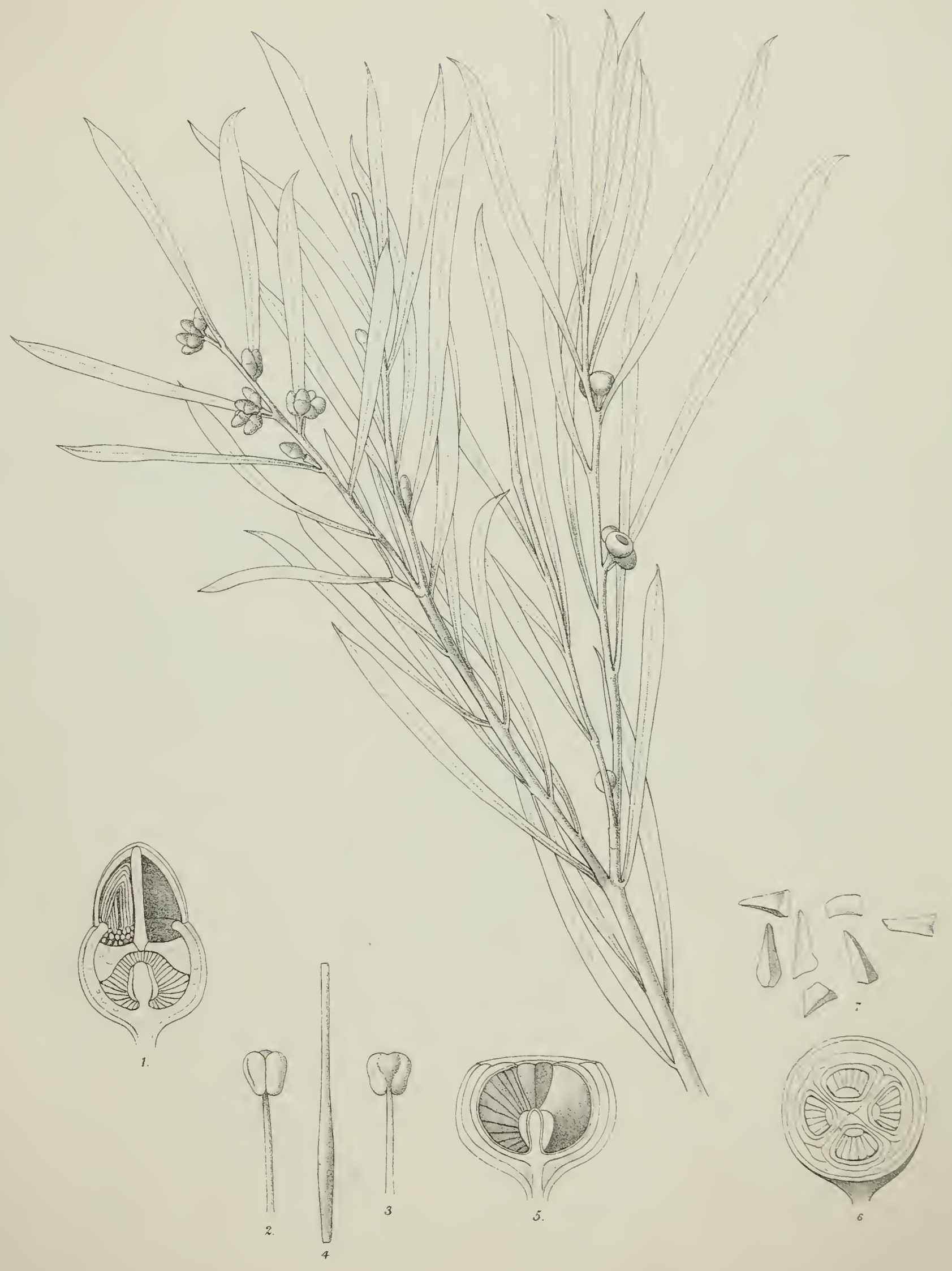

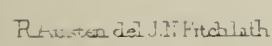

Vincent Brooks Day \& Son inge 



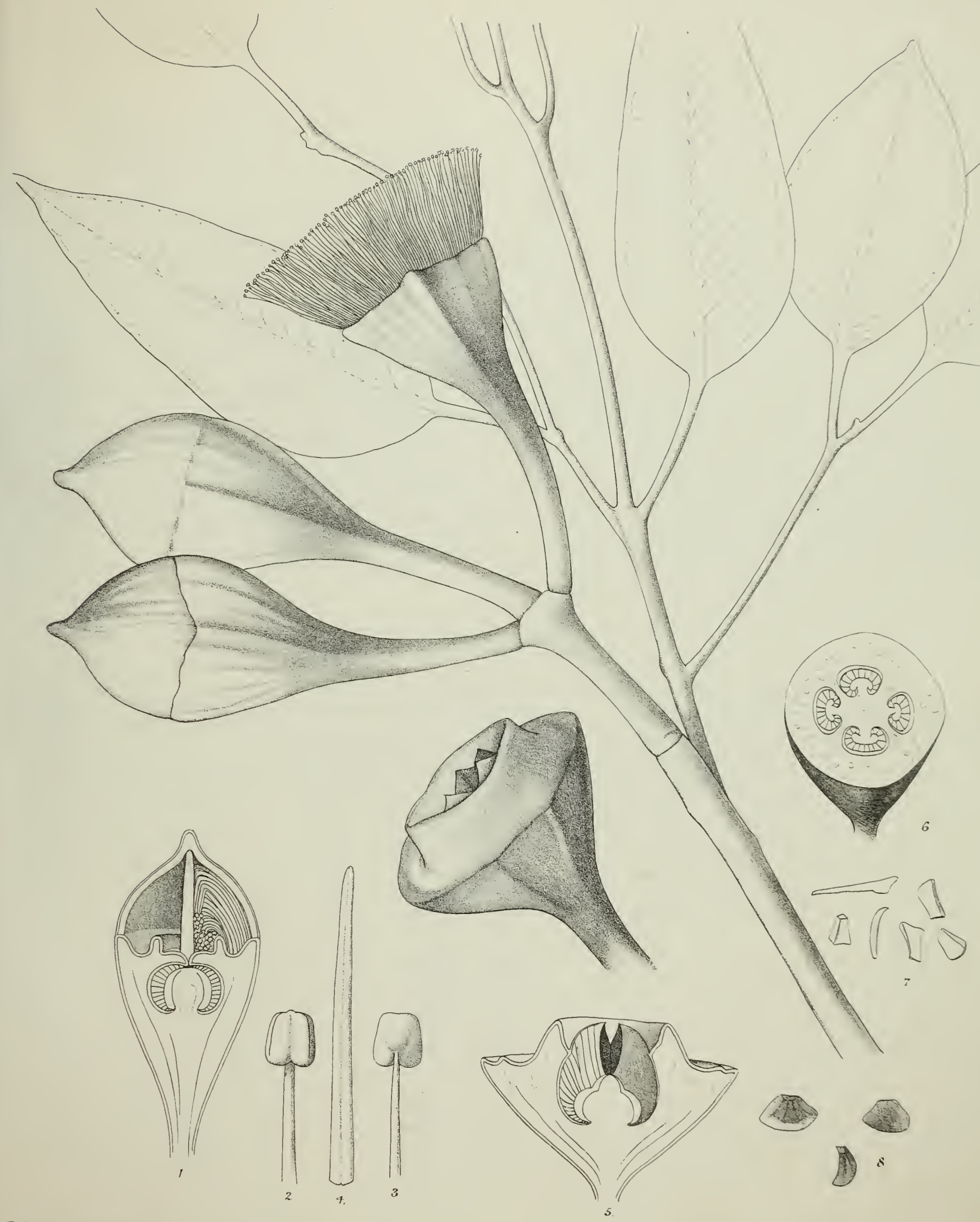

RAusten del J.NFitch Luth 



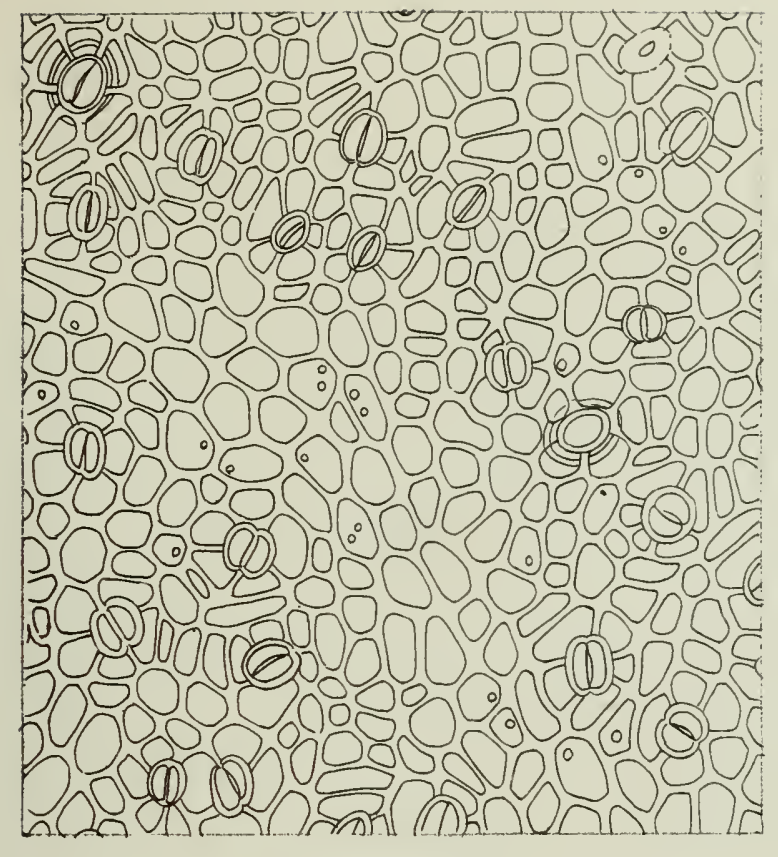

Fig 4

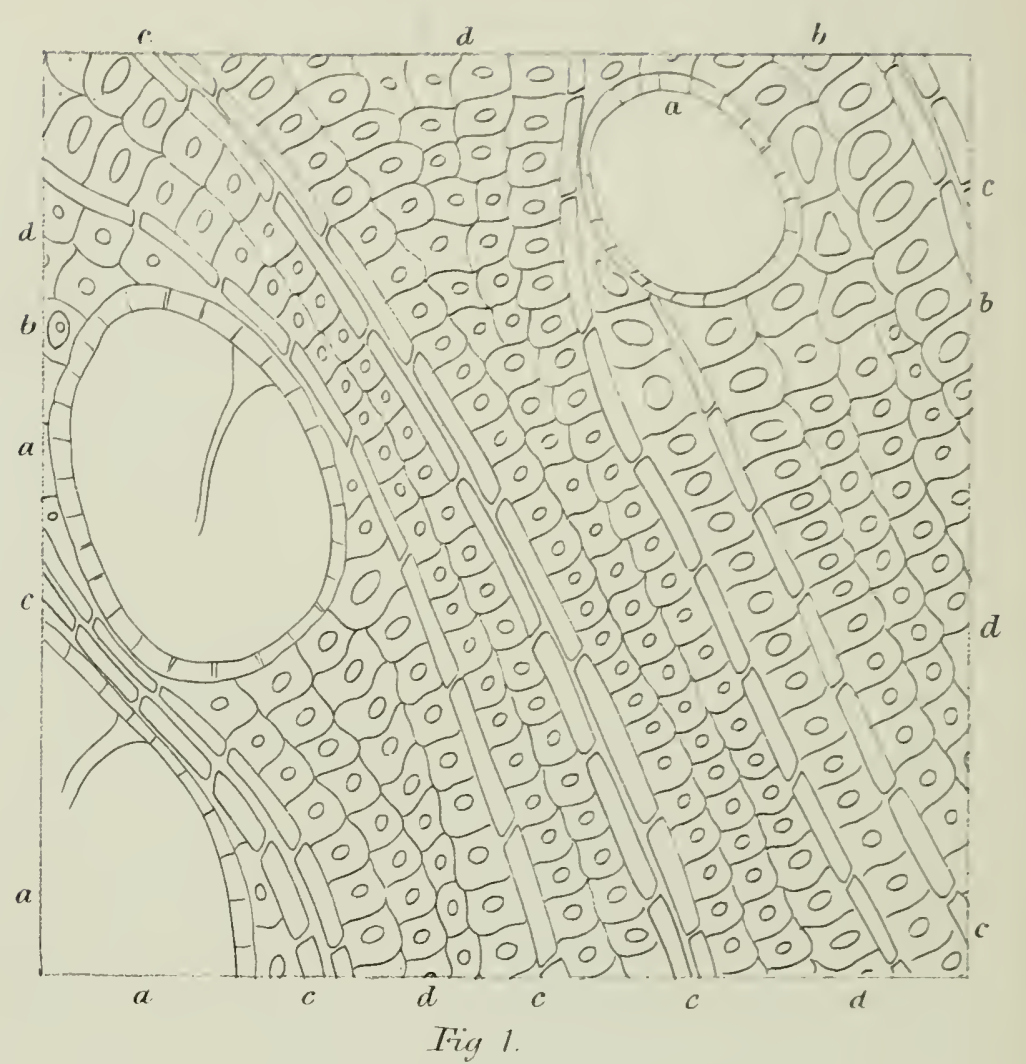

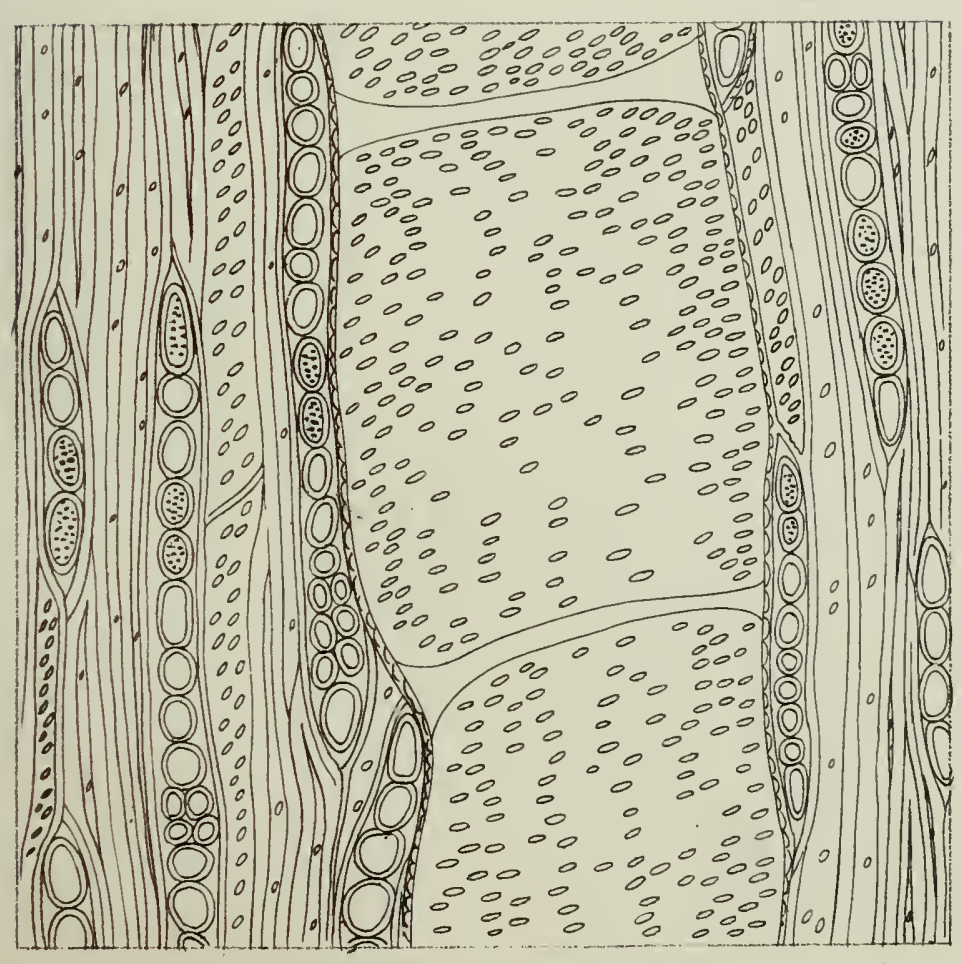

Fig 2.

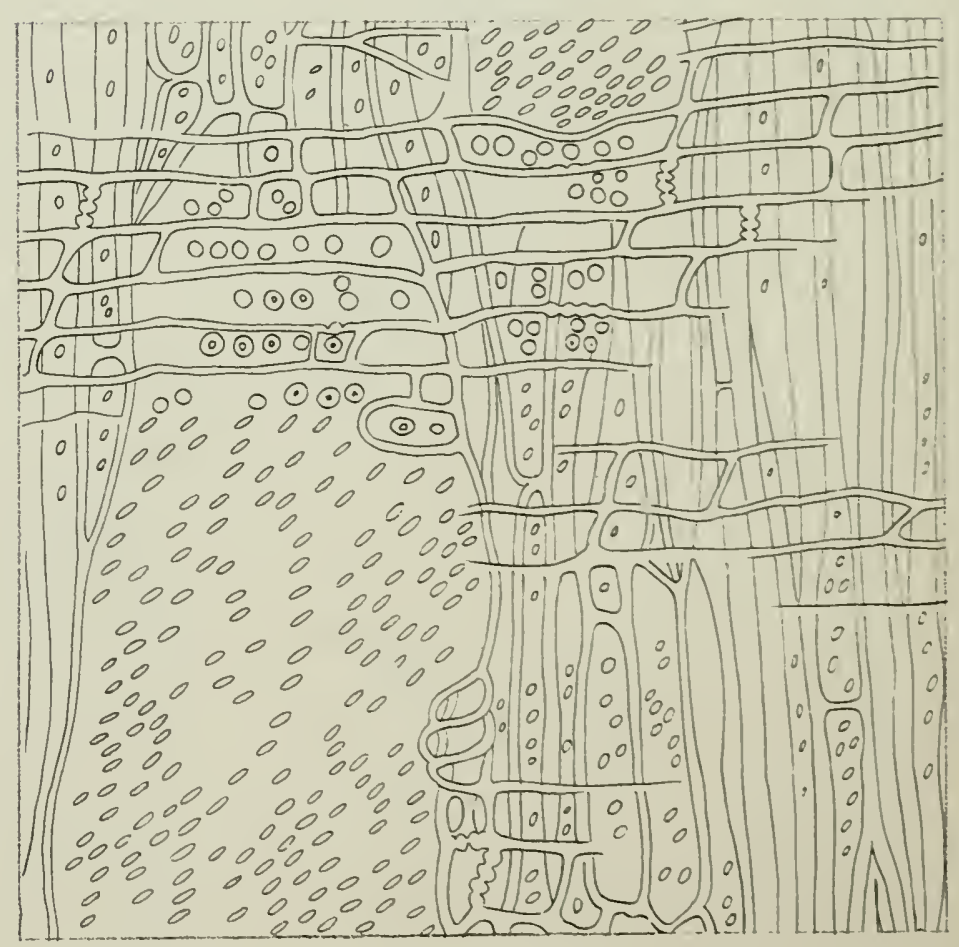

Fing $\ddot{3}$ 


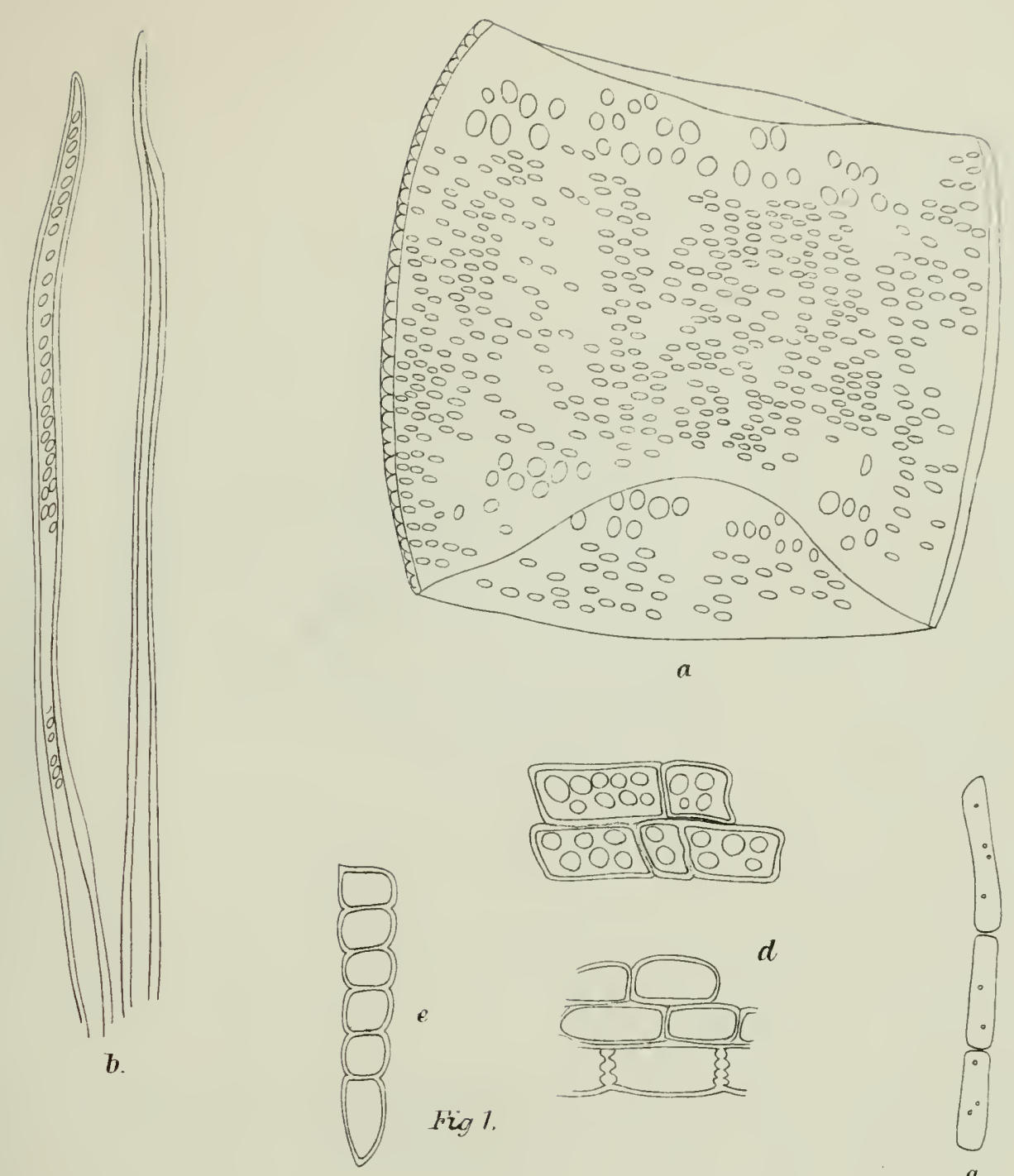

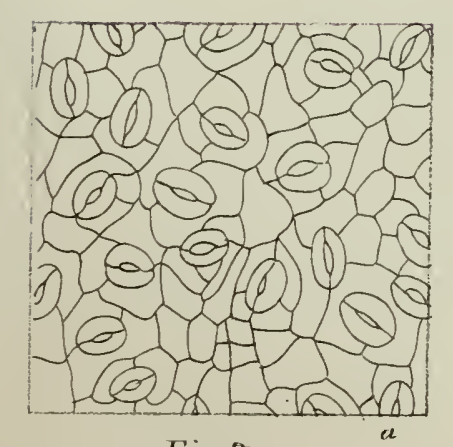

Fig 3.

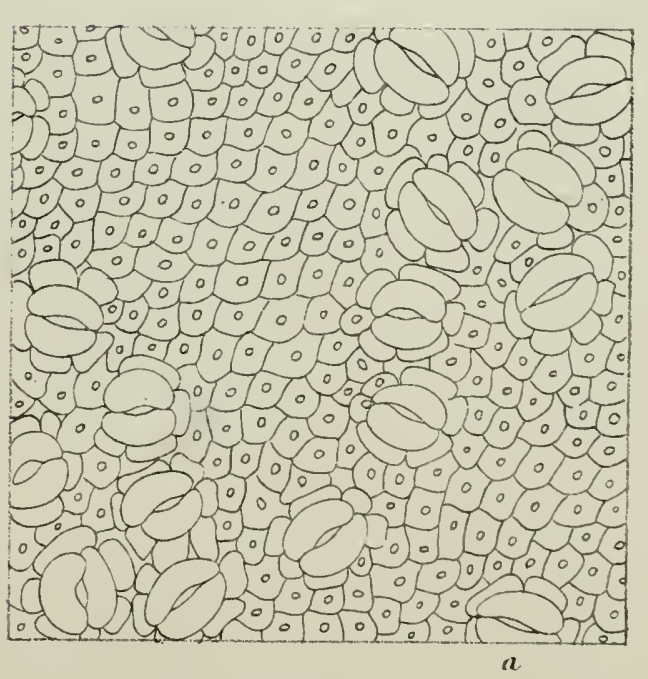

Fig 4.
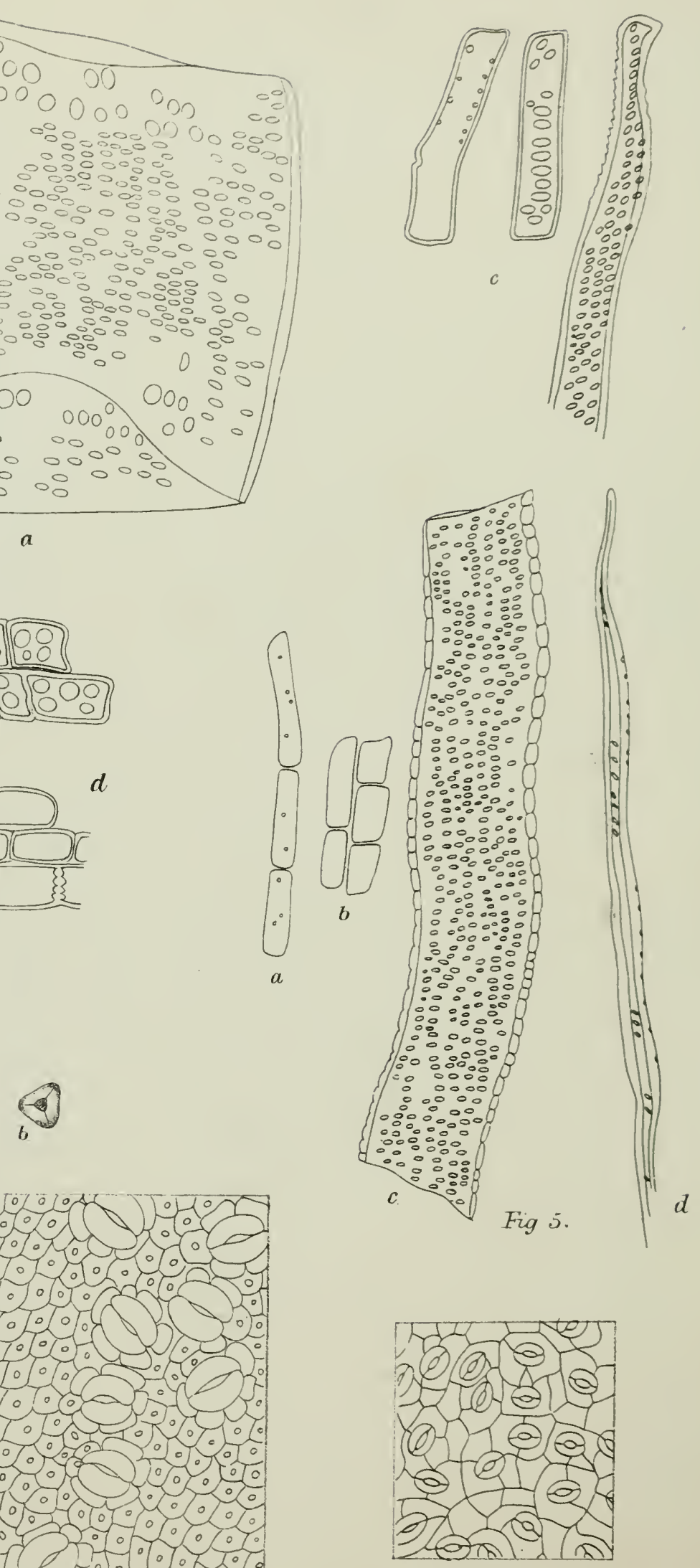

Fia: 



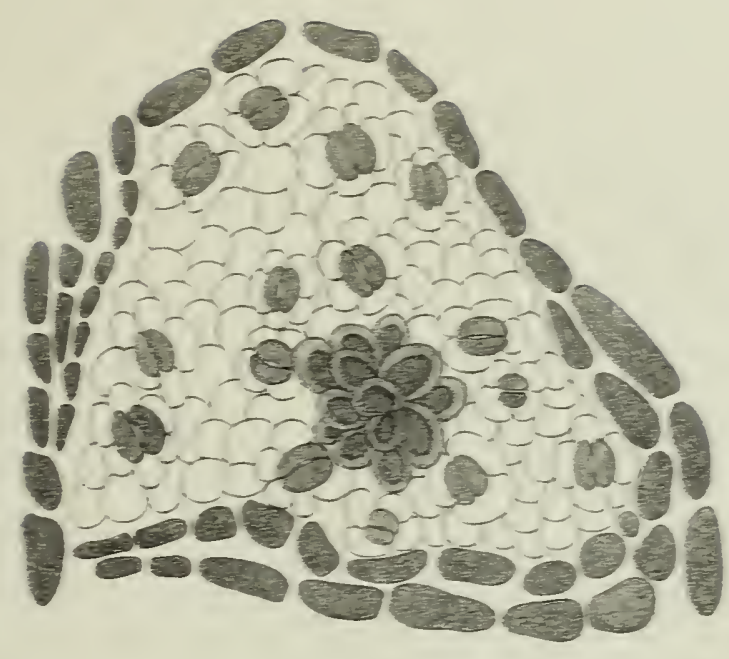

Fia 1

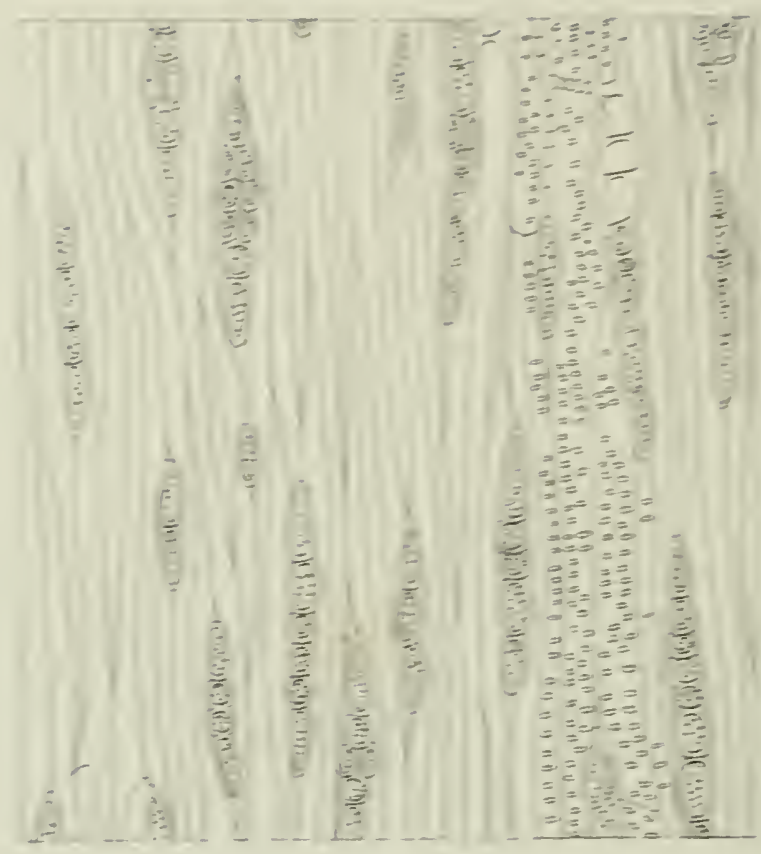

Fo 2

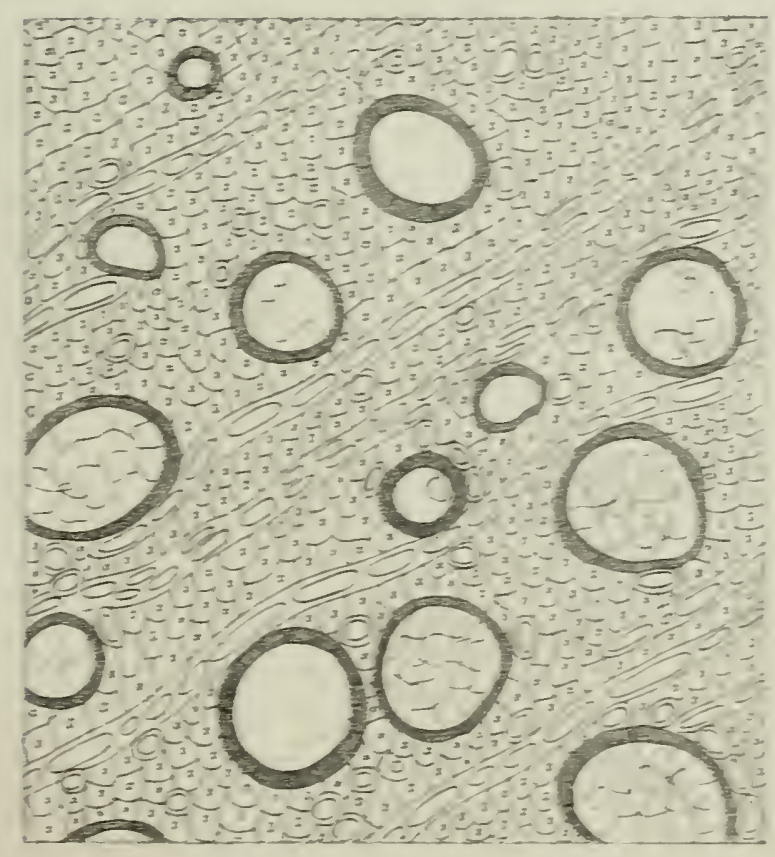

$F \rightarrow-3$

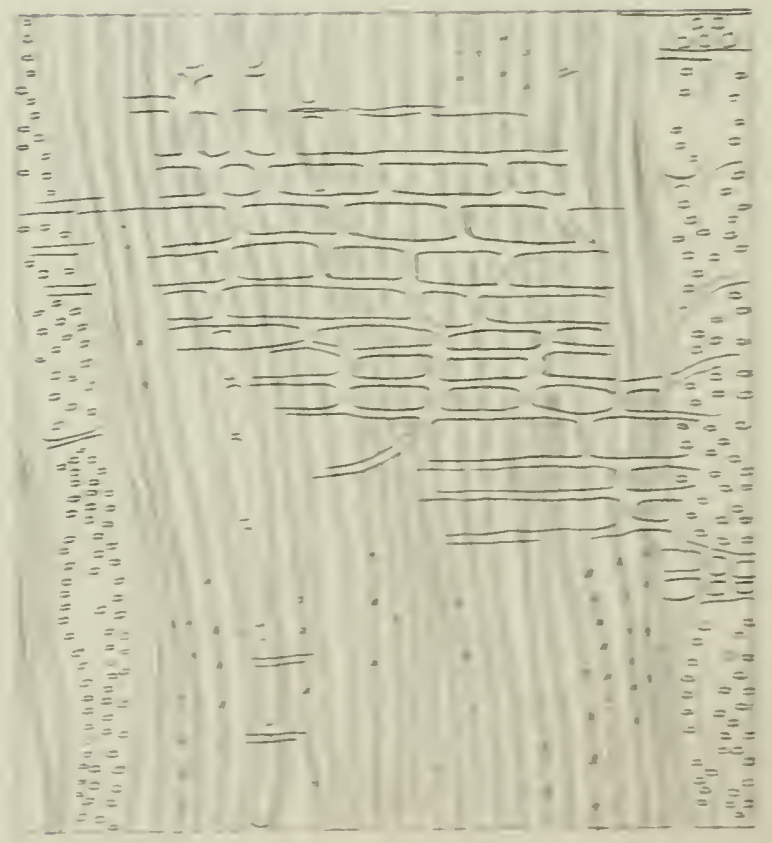

Fy 



\section{WORES ON BOTANY, PUBLISHED BY L. REEVE \& $\mathrm{C}$.}

THE NATURAL HISTORY OF PLANTS. BY H. Burics: Presiden: of the Linnean Swert of Paris, Proteseor of Medical Matural Histort, sad Direvtor of the Botanical Garden of the Facultr of Medicine of Paris. Sunet-sum Sro. Tols I. to T... with 2300 Wood Engrarings. 235 . each.

[For. TI. in the Pres.

GENERA PLANTARUM, AD ENEMPLARIA Imprimis in Herbarii = Kerreasibus serrata detinita By GDonie BnTHay. F.R.S. F.L.S.. and Sir J. D. Hower. F.P.S. Director of the Roral Gardeas, Kew. Vol. I., Part I. Foral sro, 21s. Par. II., 14s. Part III. 15s.: or Tol. I. complete, 50s. Tol II., Part I. 24s. Part II., 32s.: or VoL II. complete. its.

H.ADBOOK OF THE BRITISH FLORA : a Descripzion of the Flowering Plsn:s and Ferns indigenuus to. of naturalised in, the British Isles. For the Cse of Begincers and Amsicurs By Grorge BexthM. F.R.:. Fourth Edision, rerized, 128

DOMESTIC BOTANT: an Exposition of the Siructure and Classification of Plants, and of their ["ses for Food. Clo thing. Medicize, and Manufacturing Purposes. By Joma SxrrH, A.L.S., ex-Curator of the Roral Botanic Gardens Kew. Crown sro, 16 Coloured Plates and Wood Fingrarings, $16 z$.

OLTLINES OF BOTANY, with special refereuce ro Local Floras. B: G. Bexrius, F.R.S., F.L.S. New Edition, 1s.

LAWS OF BOTANICAL NOJENCLATURE adopted by the International Botanical Congress, with an Historical Introduction and a Commentary. By ALPHOsSE DE Caviolle. 23. 6d.

REVISION OF THE NATUPAL ORDER Hederacex, being a reprint, with numerous additions and corrections, of a series of papers published in the "Journal of Botany, British and Foreign." By Berthold Sefuxis. Ph.D., F.L.S. 7 Plates, 10z. ful.

THE BOTANICAL MAGAZLNE; Figures and Descriptions of New and Rare Plants of Interest to the Botansal Student, and suitable for the Garden, Store, or Greenhouse. Bร Sir J. D. Hooker, C.B., F.R.S., Director of the Royal Gardens, Kew. Royal 8ro. Published Monthly, with 6 Plates, 38. Gd. coloured. Annual Subscription, 423. Pe-Isste of the ThiR. SERIes in monthly rols., 423 . each: to Subscribers for the entire series, 36.3. each.

THE FLOPAL MAGAZINE; New Series, enlarged to Royal 4to. Figures and Descriptions of the choicest New Flowers for the Garden, Store, or Conservatory. Mon:hly, with 4 beautifully Colorred Plates, $9.3 .6 d$. Annual Subscription, 42.3.

First series complete in 10 vols., with 560 beautifully Coloured Plates, fils iz. fr.

\section{COLONIAL AND FOREIGN FLORAS.}

FLORA OF BRITISH INDIA. By Sir J. D Hooker. F.R.S.. and others Parts I. to TT., I0s. bis. each. Tol. I., 32:s.

FLORA ACSTRALIENSIS : a Description of the Plants of the Anstralian Territort. Br G. BEtrak. F.R.S. F.L.S. assisted by F. Mrahief, F.R.S.. Governaen: Botanis, Melbourne, Victoria Complete in $;$ Tols. Tols. I. to VI. 20s. each. Vol. TII., 24s. Published wader the auspices of the sereral Grorernments of Australia.

FLORA OF MAURITIUS AND THE SEYCHELLES: a Description of the Flowering Plants and Ferns of those Islands. Br J. G. BAEER, F.L.S. Complese in 1 Vol.. 24s. Priblished under the authority of th Colonial Gorernment of Mlauritius.

FLORA CAPENSIS: a Systematic Description of the Plants of the Cape Colony, Caffraria and Por Natal. By W. H. Hartex, M.D., F.R.S.. Professor of Botany in the Cnirersity of Dublin. and OTwO WILHeLN SusDes, $\mathrm{Ph} . \mathrm{D}$. Tols. I. and II., each 12s. Tol. III., $18 s$.

FLORA OF TROPICAL AFRICA. BY DANIEL Oliter, F.R.S., F.L.S. Vols. I. to IIL, each 20s. Pablished under the autboritr of the Firsi Commissioner of Her Majesty's Works.

HANDBOOK OF THE NEW ZEALAND FLORA : a Srstematic Description of the Native Plants of Nerr Zealand, and the Chathan, Kermadec's, Lord Auciland"s. Campbell's, and Iacquarrie's Islands. Br Sir .T. D. Hooker, F.R.S. Complete in 1 Tol.. 30s. Published under the anspices of the Gorernment of that Colong.

FLORA OF THE BRITISH WVEST INDIAN ISLANDS. By Dr. Grisebach, F.L.S. 3\%. 6. Published under the auspices of the Secretary of State fir the Colonies.

FLORA HONGKONGENSIS : a Description of the Florering Plants and Ferns of the Island of IIorgkong. By George Bextbast, F.R.S., F.L.S. With a Map of the Island and Supplement by Dr. HAice, 18s. Published under the authority of Her Majesty's Secretary of State for the Colonies. The Supplemen separately, 28 . $6 d$.

FLORA VITIENSIS : a Description of the Plants of the Viti or Fiji Islands, with an Account of their History.

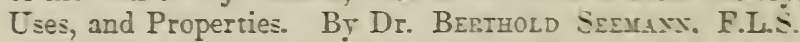
Royal 4to, 100 Coloured Plates, complete in 1 Vol.. cloth, fs $5 s$.

FLOPA OF TASMANIA. Br Sir J. D. Hooker, F.R.S. Rogal 4to, 2 Vols., 200 Plates, \pm 17 10s. Coloured. Published under the authority of the Lords Commissiozerof the Admiralty.

ON THE FLORA OF AUSTRALIA: its Origin, Affinities, and Distribution. Br Sir J. D. HookEr, F.R.S. 10 s.

CONTRIBUTIONS TO THE FLORA OF MEITONE, and to a Winter Flora of the Ririera, including the Coast from Marseilles to Genoa. Br J. Tragerrit Moggridage. Rogal sro. Complete in 1 Tol., 93 Coluureal Plates, 63s.

L. REEVE \& CO., 5, Henrietta Street, Corent Garden. 



\section{WORKS ON BOTANY, PUBLISHED BY L. REEVE \& CO.}

THE NATURAL HISTORY OF PLANTS. By H. Baillon, President of the Linnæan Society of Paris, Professor of Medical Natural History, and Director of the Botanical Garden of the Faculty of Medicine of Paris. Super-royal 8vo. Vols I. to V., with 2300 Wood Engravings, 25s. each.

[Vol. VI. in the Press.

GENERA PLANTARUM, AD EXEMPLARIA Imprinis in Herbariis Kewensibus servata definita. By George Benthaji, F.R.S., F.L.S., and Sir J. D. Hooker, F.R.S., Director of the Royal Gardens, Kew. Vol. I., Part I., Royal 8vo, 21s. Part II., 14s. Part III., 15s.; or Vol. I. coniplete, 50s. Vol. II., Part I., 24s. Part II., 32s. ; or Vol. II. complete, $56 s$.

HANDBOOK OF THE BRITISH FLORA : a Description of the Flowering Plants and Ferns indigenuus to, or naturalised in, the British Isles. For the Use of Beginners and Amateurs. By George Benthiam, F.R.S. Fourth Edition, revised, $12 \mathrm{~s}$.

DOMESTIC BO'TANY: an Exposition of the Structure and Classification of Plants, and of their Uses for Food, Clothing, Medicine, and Manufacturing Purposes. By Jону Sмтт, A.L.S., ex-Curator of the Royal Botanic Gardens, Kew. Crown 8vo, 16 Coloured Plates and Wood Engravings, $16 s$.

OUTLINES OF BOTANY, with special reference to Local Floras. By G. Benthas, F.R.S., F.L.S. New Edition, $1 s$

LAWS OF BOTANICAL NOMENCLATURE adopted by the International Botanical Congress, with an Historical Introduction and a Commentary. By ALPHONSE DE CANDOLle. $2 s .6 d$.

REVISION OF THE NATURAL ORDER Hederaceæ, being a reprint, with numerous additions and corrections, of a series of papers published in the "Journal of Botany, British and Foreign." By Berthold Seemann, Ph.D., F.L.S. 7 Plates, 10s. $6 d$.

THE BOTANICAL MAGAZINE; Figures and Descriptions of New and Rare Plants of Interest to the Botanical Student, and suitable for the Garden, Stove, or Greenhouse. By Sir J. D. Hooker, C.B., F.R.S., Director of the Royal Gardens, Kew. Royal 8vo. Published Monthly, with 6 Plates, 3s. $6 d$. coloured. Annual Subscription, $42 s$.

Re-Issue of the Tuird Series in monthly vols., $42 s$. each; to Subscribers for the entirs series, $36 s$. each.

THE FLORAL MAGAZINE; New Series, enlarged to Royal 4to. Figures and Descriptions of the choicest New Flowers for the Garden, Stove, or Conservatory. Monthly, with 4 beautifully Coloured Plates, $3 s .6 d$. Annual Subscription, $42 s$.

First series complete in 10 vols., with 560 beautifully Coloured Plates, $£ 18$ 7s. $6 d$.
COLONIAL AND FOREIGN FLORAS.

FLORA OF BRITISH INDIA. By Sir J. I Hooker, F.R.S., and others. Parts I. to VI., 10s, fid. each. Vol. I., 32s.

FLORA AUSTRALIENSIS : a Description of the Plants of the Australian Territory. By G. Bехтная, F.R.S., F.L.S., assisted by F. MUELLER, F.R.S., Government Botanist, Melbourne, Victoria. Complete in 7 Vols. Vols. I. to VI. 20s. each. Vol. VII., 24s. Published under the auspices of the several Governments of Australia.

FLORA OF MAURITIUS AND THE SEYCHELLES : a Description of the Flowering Plants and Ferns of those Islands. By J. G. BAker, F.L.S. Complete in 1 Vol., 24s. Published under the authority of th Colonial Government of Mauritius.

FLORA CAPENSIS: a Systematic Description of the Plants of the Cape Colony, Caffraria, and Port Natal. By W. H. Harver, M.D., F.R.S., Professor of Botany in the University of Dublin, and OtTo Wilhelss SONDER, $\mathrm{Ph.D.}$ Vols. I. and II., each 12s. Vol. III., $18 s$.

FLORA OF TROPICAL AFRICA. By DANiEL OLiver, F.R.S., F.L.S. Vols. I. to III., each 20s. Published under the authority of the First Commissioner of Her Majesty's Works.

HANDBOOK OF THE NEW ZEALAND FLORA : a Systematic Description of the Native Plants of New Zealand, and the Chatham, Kermadec's, Lord Auckland's, Campbell's, and Macquarrie's Islands. By Sir J. D. Hooker, F.R.S. Complete in 1 Vol., 30s. Published under the auspices of the Government of that Colony.

FLORA OF THE BRITISH IVEST INDIAN ISLANDS. By Dr. Grisebach, F.L.S. 3i $s$. 6d. Published under the auspices of the Secretary of State for the Colonies.

FLORA HONGKONGENSIS : a Description of the Flowering Plauts and Ferns of the Island of Ilor.zkong. By George Bexthas, F.R.S., F.L.S. With a Map of the Island and Supplement by Dr. HAxCE, 18s. Published under the authority of Her Majesty's Secretary of State for the Colonies. The Supvlement separately, 2s. $6 d$.

FLORA VITIENSIS : a Description of the Plants of the Viti or Fiji Islands, with an Account of their Jistors, Uses, and Properties. By Dr. Berinold Seejrary, F.L.S. Royal 4to, 100 Coloured Plates, complete in 1 Vol., clotl, $£ 85$ s.

FLORA OF TASMANIA. By Sir J. D. Hоokel, F.R.S. Royal 4to, 2 Vols., 200 Ilates, $£ 17$ 10s. Coloured. Published under the authority of the Lords Commissioner: of the Admiralty.

ON THE FLORA OF AUSTRALIA : its Origin, Affinities, and Distribution. By Sir J. D. HоoкEr, F.R.S. 10s.

CONTRIBUTIONS TO THE FLORA OF MENTONE, and to a Winter Flora of the Riviera, including the Coast from Marseilles to Genoa. By J. Tranerixi: Moggringe. Royal sro. Complete in 1 Vol., 99 Coloured Plates, 63s.

L. REEVE \& CO., 5, Henrietta Street, Covent Garden. 


\section{WORKS ON BOTANY-(continued).}

BRITISH FERNS : an Introduction to the Study of the Ferss, Lrcorods, and Equiseta indigenous to the British Isles. With Chapters on the Structure, Propagation, Cultivation, Diseases, Uses, Preservation, and Distributiou of Ferns. By M. Plues. Crown Svo, 16 Coloured Plates, and 55 Wood Engravings, $10 \mathrm{~s} .6 \mathrm{~d}$.

THE BRITISH FERNS; Coloured Figures and Descriptions, with Analysis of the Fructification and Venation of the Ferns of Great Britain and Ireland. By Sir W. J. Ноокек, F.R.S. Royal 8vo, 66 Coloured Plates, $£ 22 s$.

GARDEN FERNS; Coloured Figures and Descriptions, with Analysis of the Fructification and Venation of a Selection of Exotic Ferns, adapted for Cultivation in the Garden, Hothouse, and Conservatory. By Sir W. J. Но0кеn, F.R.S. Royal 8vo, $6 \pm$ Coloured Plates, $£ 22 s$.

FILICES EXOTIC $\not$; Coloured Figures and Description of Exotic Ferns. By Sir W. J. Hooker, F.R.S. Royal 4to, 100 Coloured Plates, $£ 611$ s.

HANDBOOK OF BRITISH MOSSES, containing all that are known to be natives of the British Isles. By the Rev. M. J. Berkeley, M.A., F.I.S. 24 Coloured Plates, $21 s$.

OUTLINES OF BRITISH FUNGOLOGY, containing Characters of above a Thousand Species of Fungi, and a Complete List of all that have been described as Natives of the British Isles. By the Rev. MI. J. Berkeley, M.A., F.L.S. 24 Coloured Plates, 30 s.

THE ESCULENT FUNGUSES OF ENGLAND, containing an Account of their Classical History, Uses, Characters, Development, Structure, Nutritious Properties, Modes of Cooking and Preserving, \&c. By C. D. BADHAM, M.D. Second Edition. Edited by F. Currer, F.R.S. 12 Coloured Plates, $12 s$.

HYCOLOGIA BRITANNICA; or, History of British Seaweeds, containing Coloured Figures, Generic and Specific Characters, Synonyms and Descriptions of all the Species of Algæ inhabiting the Shores of the British Islands. By Dr. W. H. Harvey, F.R.S. I̦̣ew Edition. Royal 8vo, 4 Vols., 360 Coloured Plates, $£ 710$ s.

PHYCOLOGIA AUSTRALICA ; or, History of Australian Seaweeds, comprising Coloured Figures and Descriptions of the more characteristic Marine Algæ of New South Wales, Victoria, Tasmania, South Australia and Western Australia, and a Synopsis of all known Australian Algæ. By Dr. Harver, F.R.S. Royal 8vo, 5 Vols., 300 Coloured Plates, $£ 7$ 13s.

BRITISH SEAWEEDS : an Introduction to the Study of the Marine Algæ of Great Britain, Ireland, and the Channel Islands. By S. O. Gray. Crown 8vo, 16 Coloured Plates, $10 s .6 d$.
ILLUSTRATIONS OF THE NUEVA QUINOLOGIA OF PAVON, with Observations on the Barks described. By J. E. Howard, F.L.S. With 27 Coloured Plates by W. Fiтch. Imperial folio, half morocco, gilt edges, $£ 66 s$.

THE QUINOLOGY OF THE EAST INDIAN PLANTATIONS. By J. E. Howard, F.L.S. Folio. Parts II. and III., with 10 Coloured and 2 Plain Plates, and 2 Photo-prints, cloth $63 s$., or complete in $1 \mathrm{Vol} ., 84 s$.

ORCHIDS : and How to Grow them in India and other Tropical Climates. By Samuel Jennings, F.L.S., F.R.H.S., late Vice-President of the Agri-Horticultural Society of India. With 48 Coloured Plates. Royal 4to. Complete in 1 Vol., cloth, gilt edges, 63 .

A SECOND CENTURY OF ORCHIDACEOUS PLANTS, selected from the Subjects published in Curtis's "Botanical MIagazine" since the issue of the "First Century." Edited by JaMes BatEjan, Esq., F.R.S. Complete in 1 Vol., royal 4to, 100 Coloured Plates, $£ 55$ s.

Dedicated by Special Permission to H.R.H. the Princess of Wales. MONOGRAPH OF ODONTOGLOSSUM, a Genus of the Vandeous Section of Orchidaceous Plants. By Jayes Bateman, Esq., F.R.S. Imperial folio, complete in 1 Vol., 30 Coloured Plates, half morocco/gilt edges, $£ 77 \mathrm{~s}$.

SELECT ORCHIDACEOUS PLANTS. By Roberit Warner, F.R.H.S. With Notes on Culture by B. S. Williars. Folio, with 40 Coloured Plates, cloth gilt, $£ 77$ s.

Second Series, complete, with 39 Coloured Plates, $£ 77 s$.

THE RHODODENDRONS OF SIKKIMHIMALAYA : being an Account, Botanical and Geographical, of the Rhododendrons recently discovered in the Mountains of Eastern Himalaya, by Dr. J. D. Hooker, F.R.S. By Sir W. J. Ноокеr, F.R.S. Folio, 30 Coloured Plates, $£ 4$ 14s. $6 \mathrm{~d}$.

THE NARCISSUS, ITS HISTORY AND CULTURE, with Coloured Figures of all known Species and principal Varieties. By F. W. Burbidge, and a Review of the Classification by J. G. BAkER, F.L.S. Super-royal Svo, 48 Coloured Plates, $32 s$.

BRITISH WILD FLOWERS, Familiarly Described in the Four Seasous. By Thomas Moore, F.L.S. 24 Coloured Plates, $16 s$.

BRITISH GRASSES : an Introduction to the Study of the Grasses found in the British Isles. By M. Plues. Crown Svo, 16 Coloured Plates, and 100 Wood Engravings, 10s. $6 d$. 




\section{Old \\ Beoks DATE DUE}

\begin{tabular}{l|l|l|l}
\hline \hline & & & \\
\hline & & & \\
\hline & & & \\
\hline & & & \\
\hline & & & \\
\hline & & & \\
\hline & & & \\
\hline & & & \\
\hline & & & \\
\hline & & & \\
\hline & & & \\
\hline
\end{tabular}

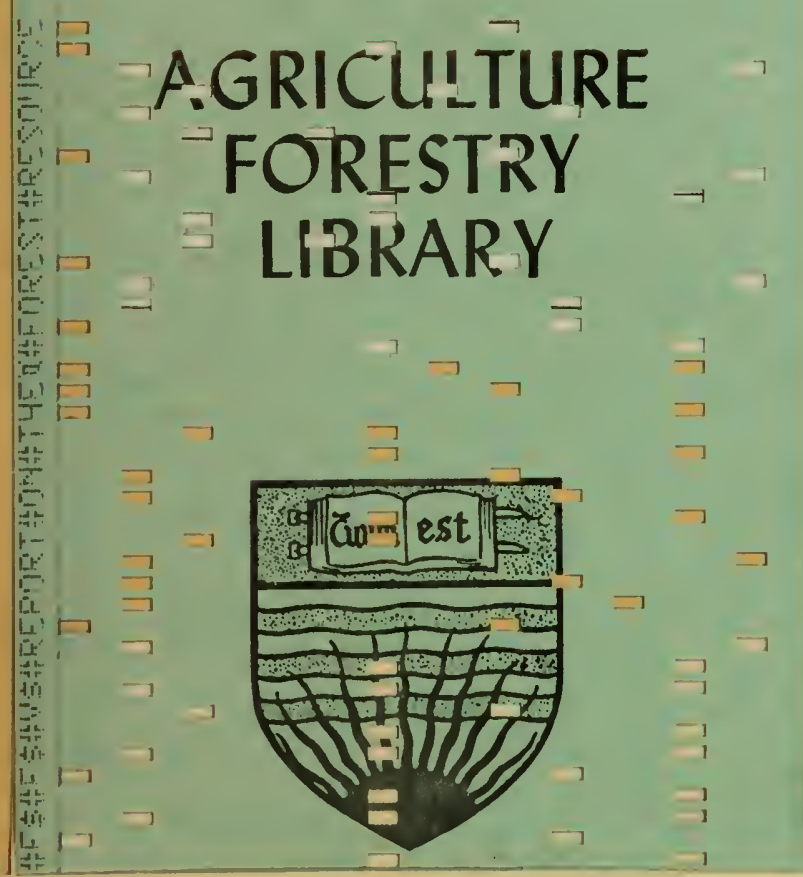




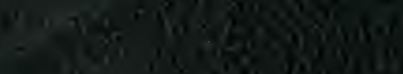

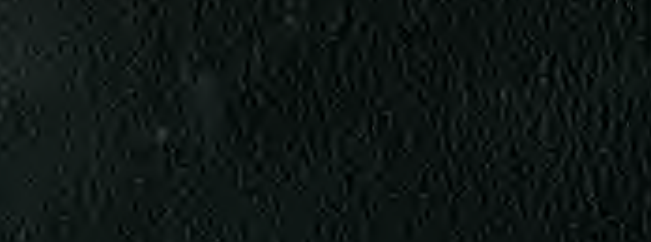

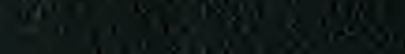

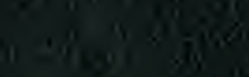

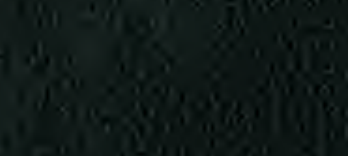

